\title{
Omega-3 fatty acids from Supplements Consumed before and during Pregnancy and Lactation and Developmental Milestones, Including Neurocognitive Development, in the Child: A Systematic Review
}

\author{
2020 Dietary Guidelines Advisory Committee, \\ Pregnancy and Lactation Subcommittee \\ Published date: July 15, 2020
}

Nutrition Evidence Systematic Review Center for Nutrition Policy and Promotion

Food and Nutrition Service

U.S. Department of Agriculture

Braddock Metro Center II

1320 Braddock Place

Alexandria, Virginia 22314 
This systematic review was conducted by the 2020 Dietary Guidelines Advisory Committee in collaboration with the Nutrition Evidence Systematic Review (NESR) team at the Center for Nutrition Policy and Promotion, Food and Nutrition Service, U.S. Department of Agriculture (USDA). All systematic reviews from the 2020 Advisory Committee Project are available on the NESR website: https://nesr.usda.gov/2020-dietaryguidelines-advisory-committee-systematic-reviews.

Conclusion statements drawn as part of this systematic review describe the state of science related to the specific question examined. Conclusion statements do not draw implications, and should not be interpreted as dietary guidance. This portfolio provides the complete documentation for this systematic review. A summary of this review is included in the 2020 Advisory Committee's Scientific Report available at www.DietaryGuidelines.gov.

The contents of this document may be used and reprinted without permission. Endorsements by NESR, the Center for Nutrition Policy and Promotion, the Food and Nutrition Service, or the USDA of derivative products developed from this work may not be stated or implied.

Suggested citation for this systematic review: 2020 Dietary Guidelines Advisory Committee and Nutrition Evidence Systematic Review Team. Omega-3 fatty acids from Supplements Consumed before and during Pregnancy and Lactation and Developmental Milestones, Including Neurocognitive Development in the Child: A Systematic Review. 2020 Dietary Guidelines Advisory Committee Project. Alexandria, VA: U.S. Department of Agriculture, Food and Nutrition Service, Center for Nutrition Policy and Promotion, July 2020. Available at: https://nesr.usda.gov/2020-dietary-guidelines-advisory-committee-systematic-reviews.

Related citation: Dietary Guidelines Advisory Committee. 2020. Scientific Report of the 2020 Dietary Guidelines Advisory Committee: Advisory Report to the Secretary of Agriculture and the Secretary of Health and Human Services. U.S. Department of Agriculture, Agricultural Research Service, Washington, DC.

In accordance with Federal civil rights law and USDA civil rights regulations and policies, the USDA, its Agencies, offices, and employees, and institutions participating in or administering USDA programs are prohibited from discriminating based on race, color, national origin, religion, sex, gender identity (including gender expression), sexual orientation, disability, age, marital status, family/parental status, income derived from a public assistance program, political beliefs, or reprisal or retaliation for prior civil rights activity, in any program or activity conducted or funded by USDA (not all bases apply to all programs). Remedies and complaint filing deadlines vary by program or incident.

Persons with disabilities who require alternative means of communication for program information (e.g., Braille, large print, audiotape, American Sign Language, etc.) should contact the responsible Agency or USDA's TARGET Center at (202) 720-2600 (voice and TTY) or contact USDA through the Federal Relay Service at (800) 877-8339. Additionally, program information may be made available in languages other than English.

To file a program discrimination complaint, complete the USDA Program Discrimination Complaint Form, AD3027, found online at How to File a Program Discrimination Complaint and at any USDA office or write a letter addressed to USDA and provide in the letter all of the information requested in the form. To request a copy of the complaint form, call (866) 632-9992. Submit your completed form or letter to USDA by: (1) mail: U.S. Department of Agriculture, Office of the Assistant Secretary for Civil Rights, 1400 Independence Avenue, SW, Washington, D.C. 20250-9410; (2) fax: (202) 690-7442; or (3) email: program.intake@usda.gov.

USDA is an equal opportunity provider, employer, and lender. 


\section{ACKNOWLEDGEMENTS}

Pregnancy and Lactation Subcommittee:

- Sharon Donovan, PhD, RD, University of Illinois, Urbana-Champaign, Subcommittee Chair

- Kathryn Dewey, PhD, University of California, Davis

- Rachel Novotny, PhD, RDN, LD, University of Hawaii

- Jamie Stang, PhD, MPH, RD, University of Minnesota

- Elsie Taveras, MD, MPH, Massachusetts General Hospital, Harvard Medical School, Harvard T.H. Chan School of Public Health

- Ronald Kleinman, MD, Massachusetts General Hospital, Harvard Medical School, Vice-Chair of the 2020 Dietary Guidelines Advisory Committee

\section{Nutrition Evidence Systematic Review (NESR) Team:}

- Julie Nevins, PhD, Analyst, Panum Group ${ }^{i}$

- Ramkripa Raghavan, DrPH, MPH, MSc, Analyst, Panum Group

- Sara Scinto-Madonich, MS, Analyst, Panum Groupi

- Sudha Venkatramanan, PhD, MSc, Analyst, Panum Group

- Gisela Butera, MLIS, MEd, Systematic Review Librarian, Panum Groupi

- Nancy Terry, MS, MLS, Biomedical Librarian, National Institutes of Health Library, U.S. Department of Health and Human Services (HHS)

- Julie Obbagy, PhD, RD, Project Lead, Office of Nutrition Guidance and Analysis (ONGA), Center for Nutrition Policy and Promotion (CNPP), Food and Nutrition Service (FNS), U.S. Department of Agriculture (USDA)

\section{Federal Liaisons:}

- Jean Altman, MS, ONGA, CNPP, FNS, USDA

- Meghan Adler, MS, RDN, ONGA, CNPP, FNS, USDA

- Jenna Fahle, MSPH, RD, ONGA, CNPP, FNS, USDA (08/2019-11/2019)

\section{Project Leadership:}

- Eve Essery Stoody, PhD, Designated Federal Officer and Director, ONGA, CNPP, FNS, USDA

- Janet de Jesus, MS, RD, Nutrition Advisor, Office of Disease Prevention and Health Promotion, Office of the Assistant Secretary for Health, HHS

USDA and HHS implemented a process to identify topics and scientific questions to be examined by the 2020 Dietary Guidelines Advisory Committee. The Committee conducted its review of evidence in subcommittees for discussion by the full Committee during its public meetings. The role of the Committee members involved establishing all aspects of the protocol, which presented the plan for how they would examine the scientific evidence, including the inclusion and exclusion criteria; reviewing all studies that met the criteria they set; deliberating on the body of evidence

i Under contract with the Food and Nutrition Service, United States Department of Agriculture. 
for each question; and writing and grading the conclusion statements to be included in the scientific report the 2020 Committee submitted to USDA and HHS. The NESR team with assistance from Federal Liaisons and Project Leadership, supported the Committee by facilitating, executing, and documenting the work necessary to ensure the reviews were completed in accordance with NESR methodology. More information about the 2020 Dietary Guidelines Advisory Committee, including the process used to identify topics and questions, can be found at www. DietaryGuidelines.gov. More information about NESR can be found at NESR.usda.gov.

The Committee and NESR staff thank USDA's Agricultural Research Service for coordinating the peer review of this systematic review, and the Federal scientist peer reviewers for their time and expertise.

FUNDING SOURCE: United States Department of Agriculture, Food and Nutrition Service, Center for Nutrition Policy and Promotion, Alexandria, VA 


\section{TABLE OF CONTENTS}

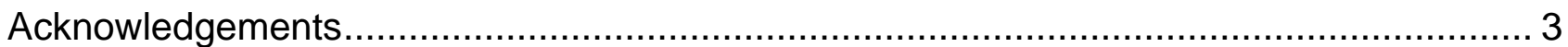

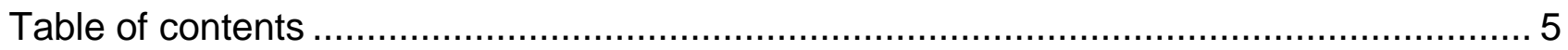

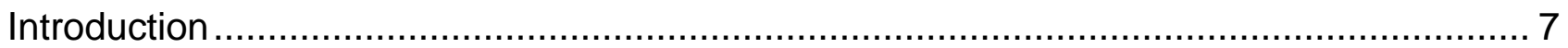

What is the relationship between omega- 3 fatty acid supplements consumed before and during pregnancy and lactation and developmental milestones, including neurocognitive

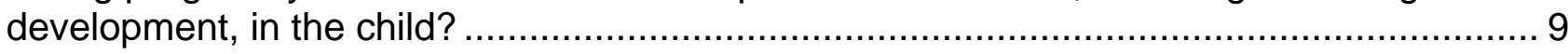

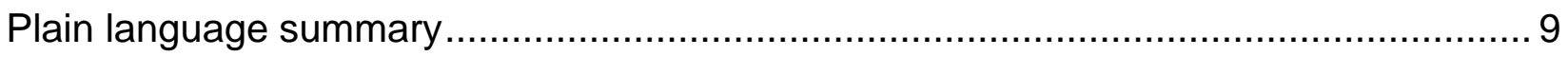

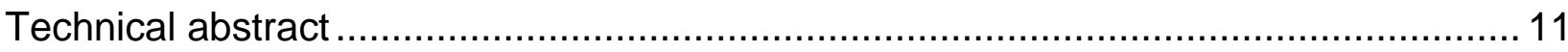

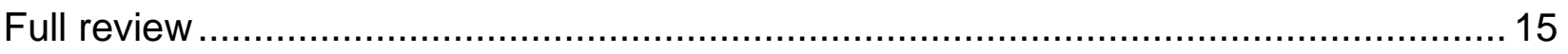

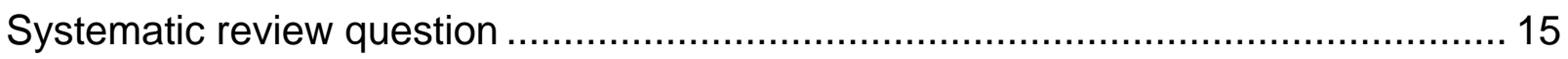

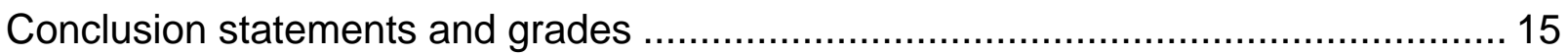

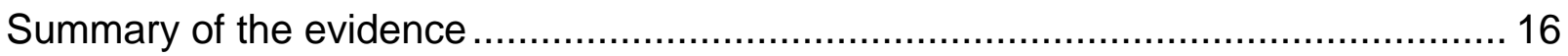

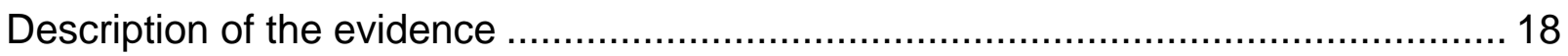

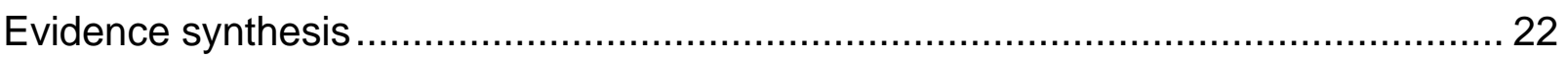

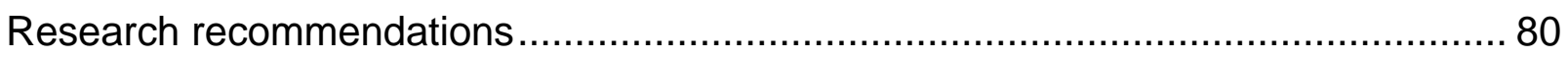

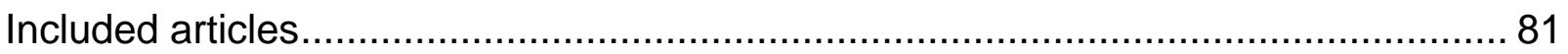

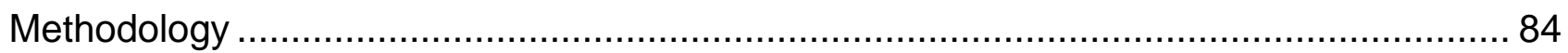

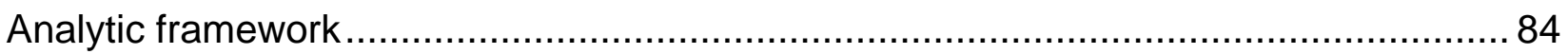

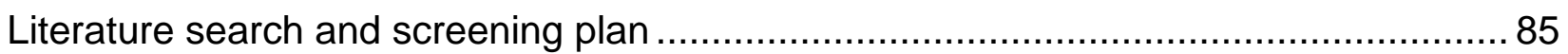

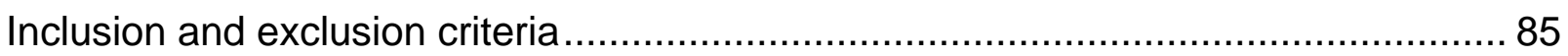

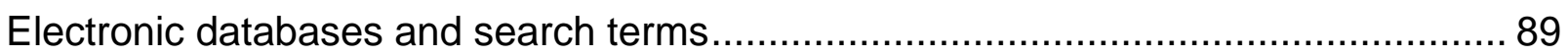

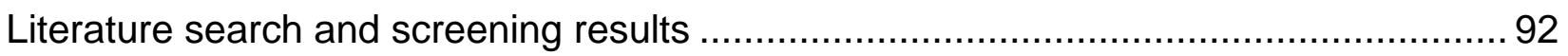

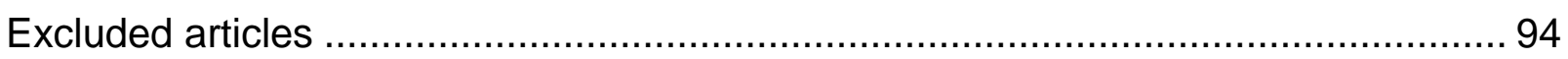

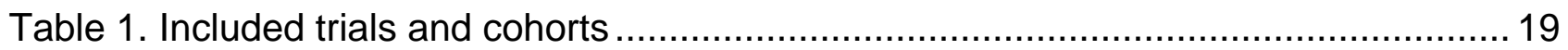

Table 2. Description of evidence on relationship between omega-3 fatty acid

supplementation and cognitive development ........................................................... 27

Table 3. Description of evidence on relationship between omega-3 fatty acid supplementation and language development ........................................................ 47

Table 4. Description of evidence on relationship between omega-3 fatty acid supplementation and motor development................................................................ 56

Table 5. Description of evidence on relationship between omega-3 fatty acid

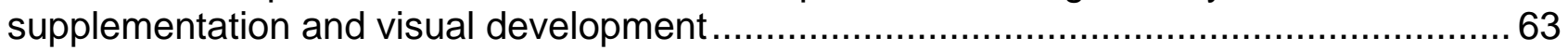

Table 6. Description of evidence on relationship between omega-3 fatty acid supplementation and social-emotional development ...................................................68

Table 7. Description of evidence on relationship between omega-3 fatty acid supplementation and academic performance, risk of ADD/ADHD, or risk of Autism spectrum disorder 
Table 8. Risk of bias for randomized controlled trials examining omega-3 fatty acid supplementation and developmental milestones, including neurocognitive development, in the child 77

Table 9. Risk of bias for observational studies examining omega-3 fatty acid supplementation and developmental milestones, including neurocognitive development, in the child 79

Table 10. Inclusion and exclusion criteria..... 86

Table 11. Articles excluded after full text screening with rationale for exclusion..... 94

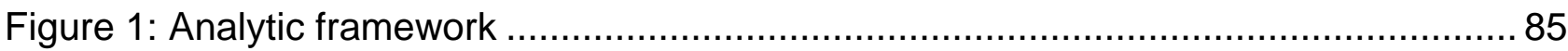

Figure 2: Flow chart of literature search and screening results. 93 
This document describes a systematic review conducted to answer the following question: What is the relationship between omega- 3 fatty acid supplements consumed before and during pregnancy and lactation and developmental milestones, including neurocognitive development, in the child? This systematic review was conducted by the 2020 Dietary Guidelines Advisory Committee, supported by USDA's Nutrition Evidence Systematic Review (NESR).

More information about the 2020 Dietary Guidelines Advisory Committee is available at the following website: www.DietaryGuidelines.gov.

NESR specializes in conducting food- and nutrition-related systematic reviews using a rigorous, protocol-driven methodology. More information about NESR is available at the following website: NESR.usda.gov.

NESR's systematic review methodology involves developing a protocol, searching for and selecting studies, extracting data from and assessing the risk of bias of each included study, synthesizing the evidence, developing conclusion statements, grading the evidence underlying the conclusion statements, and recommending future research. A detailed description of the systematic reviews conducted for the 2020 Dietary Guidelines Advisory Committee, including information about methodology, is available on the NESR website: https://nesr.usda.gov/2020-dietary-guidelines-advisory-committee-systematic-reviews. In addition, starting on page 84, this document describes the final protocol as it was applied in the systematic review. A description of and rationale for modifications made to the protocol are described in the 2020 Dietary Guidelines Advisory Committee Report, Part D: Chapter 2. Food, Beverage, and Nutrient Consumption During Pregnancy and Chapter 3. Food, Beverage, and Nutrient Consumption During Lactation. 


\section{List of abbreviations}

\begin{tabular}{ll}
\hline Abbreviation & Full name \\
\hline ADD & Attention deficit disorder \\
\hline ADHD & Attention-deficit/hyperactivity disorder \\
\hline ARA & Arachidonic acid \\
\hline ASD & Autism spectrum disorder \\
\hline CNPP & Center for Nutrition Policy and Promotion \\
\hline DHA & Docosahexaenoic acid \\
\hline EPA & Eicosapentaenoic acid \\
\hline FNS & Food and Nutrition Service \\
\hline HHS & Department of Health and Human Services \\
\hline MTHF & Methyl tetrahydrofolate \\
\hline NESR & Nutrition Evidence Systematic Review \\
\hline NIH & National Institutes of Health \\
\hline RCT & Randomized controlled trial \\
\hline PCS & Prospective cohort study \\
\hline USDA & United States Department of Agriculture \\
\hline WASI & Wechsler Abbreviated Scale of Intelligence \\
\hline WISC & Wechsler Intelligence Scale for Children \\
\hline WPPSI & Wechsler Primary and Preschool Scale of Intelligence \\
\hline
\end{tabular}




\section{WHAT IS THE RELATIONSHIP BETWEEN OMEGA-3 FATTY ACID SUPPLEMENTS CONSUMED BEFORE AND DURING PREGNANCY AND LACTATION AND DEVELOPMENTAL MILESTONES, INCLUDING NEUROCOGNITIVE DEVELOPMENT, IN THE CHILD?}

\section{PLAIN LANGUAGE SUMMARY}

\section{What is the question?}

- The question is: What is the relationship between omega-3 fatty acid supplements consumed before and during pregnancy and lactation and developmental milestones, including neurocognitive development, in the child?

\section{What is the answer to the question?}

\section{Pregnancy}

- Limited evidence suggests that omega-3 fatty acid supplementation during pregnancy may result in favorable cognitive development in the child.

- Insufficient evidence is available to determine the relationship between omega-3 fatty acid supplementation during both pregnancy and lactation, or during pregnancy only, and language and social emotional development in the child.

- Insufficient evidence is available to determine the relationship between omega-3 fatty acid supplementation during pregnancy and motor and visual development, academic performance, and the risk of attention-deficit disorder, attentiondeficit/hyperactivity disorder, and autism spectrum disorder in the child.

- No evidence is available to determine the relationship between omega-3 fatty acid supplementation during both pregnancy and lactation, or during pregnancy only, and anxiety or depression in the child.

- Insufficient evidence is available to determine the relationship between omega-3 fatty acid supplementation during both pregnancy and lactation and cognitive development in the child.

- No evidence is available to determine the relationship between omega-3 fatty acid supplementation during both pregnancy and lactation and visual development, academic performance, or the risk of attention-deficit disorder, attentiondeficit/hyperactivity disorder, or autism spectrum disorder in the child.

\section{Lactation}

- Insufficient evidence is available to determine the relationship between omega-3 fatty acid supplementation consumed during both pregnancy and lactation or during lactation alone, and cognitive, language, motor, and visual development in the child.

- No evidence is available to determine the relationship between omega-3 fatty acid supplementation consumed during both pregnancy and lactation or during lactation alone and academic performance, anxiety, depression, or the risk of attentiondeficit disorder, attention-deficit/hyperactivity disorder, or autism spectrum disorder in the child.

- No evidence is available to determine the relationship between omega-3 fatty acid 
supplementation consumed during lactation and social-emotional development in the child.

\section{Why was this question asked?}

- This important public health question was identified by the U.S. Departments of Agriculture (USDA) and Health and Human Services (HHS) to be examined by the 2020 Dietary Guidelines Advisory Committee.

\section{How was this question answered?}

- The 2020 Dietary Guidelines Advisory Committee, Pregnancy and Lactation Subcommittee conducted a systematic review to answer this question with support from the Nutrition Evidence Systematic Review (NESR) team.

\section{What is the population of interest?}

- For the intervention/exposure, generally healthy women before and/or during pregnancy and lactation.

- For the outcome, infants and toddlers (birth to 24 months) and children and adolescents (ages 2-18 years).

\section{What evidence was found?}

- This systematic review includes 33 articles that present evidence about omega-3 fatty acid supplementation during pregnancy alone ( 25 articles), during both pregnancy and lactation (6 articles), or during lactation alone (2 articles).

- Most of the evidence is about cognitive development in children. Generally, omega3 fatty acid supplementation during pregnancy alone had either no effect or a beneficial effect on child cognitive development. Although the evidence is based on studies with a strong design (randomized controlled trials), the results were somewhat inconsistent across the different measures of child cognitive development.

- Due to inconsistent results, a conclusion could not be drawn on the relationship between omega-3 fatty acid supplementation during both pregnancy and lactation or during lactation alone and cognitive development in children.

- Due to inconsistent results or an insufficient number of studies, a conclusion could not be drawn on the relationship between omega-3 fatty acid supplementation and language, motor, visual, and social-emotional development; academic performance, anxiety, and depression; and the risk of attention-deficit disorder (ADD), attentiondeficit/hyperactivity disorder (ADHD), and autism spectrum disorder (ASD).

\section{How up-to-date is this systematic review?}

- This review searched for studies from January 1980 to February 2020. 


\section{TECHNICAL ABSTRACT}

\section{Background}

- This important public health question was identified by the U.S. Departments of Agriculture (USDA) and Health and Human Services (HHS) to be examined by the 2020 Dietary Guidelines Advisory Committee.

- The 2020 Dietary Guidelines Advisory Committee, Pregnancy and Lactation Subcommittee conducted a systematic review to answer this question with support from the Nutrition Evidence Systematic Review (NESR) team.

- The goal of this systematic review was to examine the following question: What is the relationship between omega-3 fatty acid supplements consumed before and during pregnancy and lactation and developmental milestones, including neurocognitive development, in the child?

\section{Conclusion statements and grades}

- Pregnancy

- Limited evidence suggests that omega-3 fatty acid supplementation during pregnancy may result in favorable cognitive development in the child. (Grade: Limited)

- Insufficient evidence is available to determine the relationship between omega-3 fatty acid supplementation during both pregnancy and lactation, or during pregnancy only, and language and social emotional development in the child. (Grade: Grade not assignable)

- Insufficient evidence is available to determine the relationship between omega-3 fatty acid supplementation during pregnancy and motor and visual development, academic performance, and the risk of attention-deficit disorder, attention-deficit/hyperactivity disorder, and autism spectrum disorder in the child. (Grade: Grade not assignable)

- No evidence is available to determine the relationship between omega-3 fatty acid supplementation during both pregnancy and lactation, or during pregnancy only, and anxiety or depression in the child. (Grade: Grade not assignable)

- Insufficient evidence is available to determine the relationship between omega-3 fatty acid supplementation during both pregnancy and lactation and cognitive development in the child. (Grade: Grade not assignable)

- No evidence is available to determine the relationship between omega-3 fatty acid supplementation during both pregnancy and lactation and visual development, academic performance, or the risk of attention-deficit disorder, attention-deficit/hyperactivity disorder, or autism spectrum disorder in the child. (Grade: Grade not assignable)

\section{- Lactation}

- Insufficient evidence is available to determine the relationship between omega-3 fatty acid supplementation consumed during both pregnancy and lactation or during lactation alone, and cognitive, language, motor, and visual development in the child. (Grade: Grade not assignable)

- No evidence is available to determine the relationship between omega-3 
fatty acid supplementation consumed during both pregnancy and lactation or during lactation alone and academic performance, anxiety, depression, or the risk of attention-deficit disorder, attention-deficit/hyperactivity disorder, or autism spectrum disorder in the child. (Grade: Grade not assignable)

- No evidence is available to determine the relationship between omega-3 fatty acid supplementation consumed during lactation and social-emotional development in the child. (Grade: Grade not assignable)

\section{Methods}

- Literature search was conducted using 4 databases (PubMed, Cochrane, Embase, and $\mathrm{CINAHL)}$ to identify articles that evaluated an intervention or exposure of omega-3 fatty acid supplements consumed before and during pregnancy and/or lactation and the outcome of developmental milestones, including neurocognitive development, in the child. A manual search was also conducted to identify articles that may not have been included in the electronic databases searched. Articles were screened by two NESR analysts independently for inclusion based on predetermined criteria.

- Data extraction and risk of bias assessment were conducted for each included study, and both were checked for accuracy. The Committee qualitatively synthesized the body of evidence to inform development of a conclusion statement(s), and graded the strength of evidence using pre-established criteria for risk of bias, consistency, directness, precision, and generalizability.

\section{Summary of the evidence}

\section{Pregnancy only, and both pregnancy and lactation}

- This systematic review included 31 articles from 14 randomized controlled trials (RCTs) and 1 prospective cohort study (PCS) published between 1980 and 2020.

- Studies included in this review assessed interventions/exposures during:

- Pregnancy only: 11 RCTs (24 articles); 1 PCS (1 article)

- Both pregnancy and lactation: 3 RCTs (6 articles)

- 11 of the 14 RCTs assessed cognitive development

- Eight RCTs delivered omega-3 fatty acid supplements during pregnancy alone. Of those 8 RCTs, 5 studies ( 11 articles) reported at least one statistically significant finding that supplementation resulted in favorable cognitive development in the child. One study reported at least one statistically significant finding that supplementation resulted in unfavorable measures of cognitive development in the child. All 8 studies reported at least one statistically nonsignificant result. Overall, results were inconsistent across different measures both within and between studies.

- Three RCTs delivered omega-3 fatty acid supplements during both pregnancy and lactation. Of those 3 RCTs, 1 study reported at least one statistically significant finding that supplementation resulted in favorable cognitive development in the child. All 3 studies reported at least one statistically nonsignificant result.

- For language, motor, visual, and social-emotional development, findings were inconsistent and therefore a conclusion statement could not be drawn. Although all studies reported at least one statistically non-significant result, the number and direction of statistically significant findings varied across the body of evidence. 
- Only 1 study examined academic performance; therefore, a conclusion could not be drawn.

- No evidence was available on omega-3 fatty acid supplementation and anxiety or depression.

- Only 1 study (2 articles) assessed the risk of attention-deficit disorder (ADD) or attention-deficit/hyperactivity disorder (ADHD); therefore a conclusion could not be drawn.

- Only 1 RCT and 1 PCS study assessed risk of autism spectrum disorder (ASD), and both had methodological limitations; therefore, the evidence was deemed insufficient to draw a conclusion.

- The ability to draw strong conclusions was limited by the following issues:

- Wide variation in the developmental domains assessed, as well as in the measures used to evaluate child performance in each of those domains, which limited the ability to compare results across studies.

- Potential risk of bias due to missing outcome data. Further, a lack of preregistered data analysis plans potentially increased the risk of bias due to selectivity in results presented.

- Findings were mixed both within and between studies, and these inconsistencies could not be explained by methodological differences.

- Although some studies published results from multiple follow-up assessments, an insufficient number of studies were available to investigate the relationship between omega-3 fatty acid supplementation and developmental milestones in the child for many exposure-outcome pairs. Additionally, several studies did not provide evidence of sufficient sample size to detect effects, either because the study did not achieve the required sample size estimated by power calculations or because the study did not report a power calculation. This is particularly true for the long-term outcome assessments.

- People with lower socioeconomic status, adolescents, and racially and ethnically diverse populations were underrepresented in the body of evidence.

\section{Lactation only, and both pregnancy and lactation}

- This systematic review included 8 articles from 4 RCTs published between 1980 and 2020.

- Studies included in this review assessed interventions/exposures during:

- Both pregnancy and lactation: 3 RCTs (6 articles)

- Lactation alone: 1 RCT (2 articles)

- All 4 RCTs assessed cognitive development

- Three RCTs provided omega-3 fatty acid supplements during both pregnancy and lactation. Of those 3 RCTs, 1 study reported at least one statistically significant finding that supplementation resulted in favorable cognitive development in the child. All 3 studies reported at least one statistically nonsignificant result.

- One RCT provided omega-3 fatty acid supplements during lactation alone and showed a benefit of supplementation on one measure of cognitive development in the child. The study also reported statistically non-significant results on other measures of cognitive development.

- For language, motor, and social-emotional development, findings were inconsistent and therefore a conclusion statement could not be drawn. Although all studies 
reported at least one statistically non-significant result, the number and direction of statistically significant findings varied across the body of evidence.

- No evidence was available on omega-3 fatty acid supplementation and visual development, academic performance, anxiety, depression or the risk of ADD, ADHD, or ASD.

- The ability to draw strong conclusions was limited by the following issues:

- Wide variation in the developmental domains assessed, as well as in the measures used to evaluate child performance in each of those domains, limited the ability to compare results across studies.

- Missing outcome data raised concerns about risk of bias. Further, a lack of preregistered data analysis plans potentially increased the risk of bias due to selectivity in results presented.

- Findings were mixed both within and between studies, and these inconsistencies could not be explained by methodological differences.

- Although some studies published results from multiple follow-up assessments, an insufficient number of studies were available to investigate the relationship between omega-3 fatty acid supplementation and developmental milestones in the child for many exposure-outcome pairs. Additionally, multiple studies did not provide evidence of sufficient sample size to detect effects, either because the study did not achieve the required sample size estimated by power calculations or because the study did not report a power calculation. This is particularly true for the long-term outcome assessments.

- People with lower socioeconomic status, adolescents, and racially and ethnically diverse populations were underrepresented in the body of evidence. 


\section{FULL REVIEW}

\section{Systematic review question}

What is the relationship between omega- 3 fatty acids from supplements consumed before and during pregnancy and lactation and developmental milestones, including neurocognitive development, in the child?

\section{Conclusion statements and grades}

\section{Pregnancy}

Limited evidence suggests that omega-3 fatty acid supplementation during pregnancy may result in favorable cognitive development in the child. (Grade: Limited)

Insufficient evidence is available to determine the relationship between omega-3 fatty acid supplementation during both pregnancy and lactation, or during pregnancy only, and language and social emotional development in the child. (Grade: Grade not assignable)

Insufficient evidence is available to determine the relationship between omega-3 fatty acid supplementation during pregnancy and motor and visual development, academic performance, and the risk of attention-deficit disorder, attention-deficit/hyperactivity disorder, and autism spectrum disorder in the child. (Grade: Grade not assignable)

No evidence is available to determine the relationship between omega- 3 fatty acid supplementation during both pregnancy and lactation, or during pregnancy only, and anxiety or depression in the child. (Grade: Grade not assignable)

Insufficient evidence is available to determine the relationship between omega- 3 fatty acid supplementation during both pregnancy and lactation and cognitive development in the child. (Grade: Grade not assignable)

No evidence is available to determine the relationship between omega- 3 fatty acid supplementation during both pregnancy and lactation and visual development, academic performance, or the risk of attention-deficit disorder, attentiondeficit/hyperactivity disorder, or autism spectrum disorder in the child. (Grade: Grade not assignable)

\section{Lactation}

Insufficient evidence is available to determine the relationship between omega-3 fatty acid supplementation consumed during both pregnancy and lactation or during lactation alone, and cognitive, language, motor, and visual development in the child. (Grade: Grade not assignable)

No evidence is available to determine the relationship between omega- 3 fatty acid supplementation consumed during both pregnancy and lactation or during lactation alone and academic performance, anxiety, depression, or the risk of attention-deficit disorder, attention-deficit/hyperactivity disorder, or autism spectrum disorder in the child. (Grade: Grade not assignable) 
No evidence is available to determine the relationship between omega- 3 fatty acid supplementation consumed during lactation and social-emotional development in the child. (Grade: Grade not assignable)

\section{Summary of the evidence}

\section{Pregnancy only, and both pregnancy and lactation}

- This systematic review included 31 articles from 14 RCTs and 1 PCS published between 1980 and 2020. ${ }^{1-31}$

- Studies included in this review assessed interventions/exposures during:

- Pregnancy only: 11 RCTs (24 articles); 1 PCS (1 article)

- Both pregnancy and lactation: 3 RCTs (6 articles)

- 11 of the 14 RCTs assessed cognitive development

- Eight RCTs delivered omega-3 fatty acid supplements during pregnancy alone. Of those 8 RCTs, 5 studies ( 11 articles) reported at least one statistically significant finding that supplementation resulted in favorable cognitive development in the child. One study reported at least one statistically significant finding that supplementation resulted in unfavorable measures of cognitive development in the child. All 8 studies reported at least one statistically nonsignificant result. Overall, results were inconsistent across different measures both within and between studies.

- Three RCTs delivered omega-3 fatty acid supplements during both pregnancy and lactation. Of those 3 RCTs, 1 study reported at least one statistically significant finding that supplementation resulted in favorable cognitive development in the child. All 3 studies reported at least one statistically nonsignificant result.

- For language, motor, visual, and social-emotional development, findings were inconsistent and therefore a conclusion statement could not be drawn. Although all studies reported at least one statistically non-significant result, the number and direction of statistically significant findings varied across the body of evidence.

- Only 1 study examined academic performance; therefore, a conclusion could not be drawn.

- No evidence was available on omega-3 fatty acid supplementation and anxiety or depression.

- Only 1 study (2 articles) assessed the risk of attention-deficit disorder (ADD) or attention-deficit/hyperactivity disorder (ADHD); therefore a conclusion could not be drawn.

- Only 1 RCT and 1 PCS study assessed risk of autism spectrum disorder (ASD), and both had methodological limitations; therefore, the evidence was deemed insufficient to draw a conclusion.

- The ability to draw strong conclusions was limited by the following issues:

- Wide variation in the developmental domains assessed, as well as in the measures used to evaluate child performance in each of those domains, which limited the ability to compare results across studies.

- Potential risk of bias due to missing outcome data. Further, a lack of preregistered data analysis plans potentially increased the risk of bias due to 
selectivity in results presented.

- Findings were mixed both within and between studies, and these inconsistencies could not be explained by methodological differences.

- Although some studies published results from multiple follow-up assessments, an insufficient number of studies were available to investigate the relationship between omega-3 fatty acid supplementation and developmental milestones in the child for many exposure-outcome pairs. Additionally, several studies did not provide evidence of sufficient sample size to detect effects, either because the study did not achieve the required sample size estimated by power calculations or because the study did not report a power calculation. This is particularly true for the long-term outcome assessments.

- People with lower socioeconomic status, adolescents, and racially and ethnically diverse populations were underrepresented in the body of evidence.

\section{Lactation only, and both pregnancy and lactation}

- This systematic review included 8 articles from 4 RCTs published between 1980

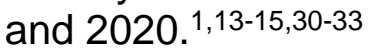

- Studies included in this review assessed interventions and exposures during:

- Both pregnancy and lactation: 3 RCTs (6 articles)

- Lactation alone: 1 RCT (2 articles)

- All 4 RCTs assessed cognitive development:

- Three RCTs provided omega-3 fatty acid supplements during both pregnancy and lactation. Of those 3 RCTs, 1 study reported at least one statistically significant finding that supplementation resulted in favorable cognitive development in the child. All 3 studies reported at least one statistically nonsignificant result.

- One RCT provided omega-3 fatty acid supplements during lactation alone and showed a benefit of supplementation on one measure of cognitive development in the child. The study also reported statistically non-significant results on other measures of cognitive development.

- For language, motor, and social-emotional development, findings were inconsistent and therefore a conclusion statement could not be drawn. Although all studies reported at least one statistically non-significant result, the number and direction of statistically significant findings varied across the body of evidence.

- No evidence was available on omega-3 fatty acid supplementation and visual development, academic performance, anxiety, depression or the risk of ADD, ADHD, or ASD.

- The ability to draw strong conclusions was limited by the following issues:

- Wide variation in the developmental domains assessed, as well as in the measures used to evaluate child performance in each of those domains, limited the ability to compare results across studies.

- Missing outcome data raised concerns about risk of bias. Further, a lack of preregistered data analysis plans potentially increased the risk of bias due to selectivity in results presented.

- Findings were mixed both within and between studies, and these inconsistencies could not be explained by methodological differences.

- Although some studies published results from multiple follow-up assessments, an insufficient number of studies were available to investigate the relationship 
between omega-3 fatty acid supplementation and developmental milestones in the child for many exposure-outcome pairs. Additionally, multiple studies did not provide evidence of sufficient sample size to detect effects, either because the study did not achieve the required sample size estimated by power calculations or because the study did not report a power calculation. This is particularly true for the long-term outcome assessments.

- People with lower socioeconomic status, adolescents, and racially and ethnically diverse populations were underrepresented in the body of evidence.

\section{Description of the evidence}

This systematic review included articles that address the relationship between omega3 fatty acid supplements ii consumed before or during pregnancy and/or lactation and developmental milestones, including neurocognitive development, in the child. The search included articles from very high and high Human Development Indexiii countries and the search timeframe spanned from January 1980 to February 2020. Studies included generally healthy women before and/or during pregnancy and lactation. The following study designs were included: RCTs, non-randomized controlled trials, prospective and retrospective cohort studies and nested case-control studies.

This body of evidence includes 33 articles from 16 studies, including 15 RCTs ${ }^{1-15,17-33}$ and 1 PCS. ${ }^{16}$ References are included for each study in Table 1 with trial/cohort names or locations when names were unavailable.

Five of the 16 studies were conducted in the United States. ${ }^{5,6,12,16,18,32,33}$ In addition, 2 studies each were conducted in Australia, $7,9-11,19,20,22,28$ Canada, $17,23,24$ and Germany, ${ }^{1-}$ 4,8 and 1 each in Hungary, ${ }^{2,3,8}$ Iran, ${ }^{25}$ Mexico, ${ }^{26,27,29}$ the Netherlands, ${ }^{30,31}$ Norway, ${ }^{13-15}$ Spain, ${ }^{2-4,8}$ and the United Kingdom. ${ }^{21}$

ii Dietary supplement was defined as a product (other than tobacco) that: is intended to supplement the diet; contains one or more dietary ingredients (including vitamins; minerals; herbs or other botanicals; amino acids; and other substances) or their constituents; is intended to be taken by mouth as a pill, capsule, tablet, or liquid; and is labeled on the front panel as being a dietary supplement (ODS; Dietary Supplement Health and Education Act, 1994). Fortification was defined as the deliberate addition of one or more essential nutrients to a food, whether or not it is normally contained in the food (FDA).

iii The Human Development classification was based on the Human Development Index (HDI) ranking from the year the study intervention occurred or data were collected (UN Development Program. HDI 1990-2017 HDRO calculations based on data from UNDESA (2017a), UNESCO Institute for Statistics (2018), United Nations Statistics Division (2018b), World Bank (2018b), Barro and Lee (2016) and IMF (2018). Available from: http://hdr.undp.org/en/data). If the study did not report the year in which the intervention occurred or data were collected, the HDI classification for the year of publication was applied. HDI values are available from 1980, and then from 1990 to present. If a study was conducted prior to 1990, the HDI classification from 1990 was applied. When a country was not included in the HDI ranking, the current country classification from the World Bank was used instead (The World Bank. World Bank country and lending groups. Available from: https://datahelpdesk.worldbank.org/knowledgebase/articles/906519-world- country-and-lending-groups). 
Table 1. Included trials and cohorts

Trial/Cohort name

Reference numbers for included article

\begin{tabular}{ll}
\hline Randomized controlled trials & \\
\hline DOMInO trialiv & $9-11,19,20,28$ \\
\hline KUDOS & 5,6 \\
\hline NUHEALiv & $2-4,8$ \\
\hline POSGRAD & $26,27,29$ \\
\hline Oslo (Norway) & $13-15$ \\
\hline Gronigen (Netherlands) & 30,31 \\
\hline Houston (USA) & 32,33 \\
\hline Perth (Australia) & 7,22 \\
\hline Vancouver (Canada) Mulder et al & 23,24 \\
\hline Pittsburgh (USA) & 18 \\
\hline Tabriz (Iran) & 25 \\
\hline INFAT & 12 \\
\hline Vancouver (Canada) Innis and Friesen & 17 \\
\hline Glasgow (UK) & 21 \\
\hline Kansas City (USA) & 12 \\
\hline Prospective Cohort Studies & 16 \\
\hline MARBLESiv & \\
\hline
\end{tabular}

Participant characteristics:

- Sample size of the RCTs ranged from $44^{12}$ to 900 participants, ${ }^{29}$ and the PCS included 258 participants. ${ }^{16}$

- All of the studies were conducted predominantly in adult women (mean age 26-34 years) who had singleton pregnancies.

iv DOMInO: DHA to Optimize Mother Infant Outcome; INFAT: The Impact of the Nutritional Fatty Acids During Pregnancy and Lactation for Early Human Adipose Tissue Development; KUDOS: Kansas University DHA Outcomes Study; MARBLES: Markers of Autism Risk in Babies-Learning Early Signs; NUHEAL: Nutraceuticals for a Healthier Life; POSGRAD: Prenatal Omega 3 Supplementation on child Growth and Development 
- Race/ethnicity: Six of the 16 studies noted that the participants were predominantly or exclusively White. $7,10,11,16,17,19,22-24,32,33$ Catena et $a^{3}$ reported that 100 percent of the children in the follow-up were White. One study exclusively included mothers from Mexico, ${ }^{26,27,29}$ and another exclusively included Black women. ${ }^{18}$ Ostadrahimi et a ${ }^{25}$ exclusively recruited Iranian women. Six percent and 31 percent of participants identified as Hispanic or Black, respectively, in the Colombo et al study. 5,6 The Gustafson et al study ${ }^{12}$ reported the following on race/ethnicity: 37.3 percent Black, 46.3 percent White, 13.4 percent Hispanic, and 3 percent Asian. Five studies did not report race/ethnicity. 1,9-11,13-15,19-21,30,31

- Socio-economic status

- Maternal education:

- A majority of the studies reported that the participants had at least some college education, on average. $1,5-7,9-17,19,20,22-24,26-33$

- Four studies did not report maternal education. ${ }^{18,21}$

- Income: Two studies included predominantly,6 or exclusively ${ }^{18}$ women with low or middle incomes and 2 studies ${ }^{3,17}$ reported that $>75$ percent of participants had middle or high incomes. In 1 study nearly 20 percent of participants reported insufficient income. ${ }^{25}$ The remaining studies did not report income.

\section{Intervention/Exposures}

\section{Supplement dose and composition}

- Seven RCTs provided docosahexaenoic acid (DHA), $5,6,12,17,21,23,24,26,27,29,32,334$ RCTs provided both DHA and eicosapentaenoic acid (EPA), ${ }^{1-4,7-11,19,20,22,25,28,30,31}$ and 1 RCT was a 2x2 trial of DHA and arachidonic acid (ARA). ${ }^{30,31}$ In addition to DHA and EPA, Keenan et al ${ }^{18}$ also provided $40 \mathrm{mg} / \mathrm{d}$ docosapentaenoic and $90 \mathrm{mg} / \mathrm{d}$ eicosatetraenoic acids. Helland et $\mathrm{al}^{13-15}$ provided $10 \mathrm{~mL} / \mathrm{d}$ cod liver oil.

- DHA dose ranged from $120 \mathrm{mg} / \mathrm{d}$ to $2.2 \mathrm{~g} / \mathrm{d}$ and EPA dose ranged from 100 $\mathrm{mg} / \mathrm{d}$ to $1.1 \mathrm{~g} / \mathrm{d}$.

- Most of the RCTs included a placebo composed of corn oil, ${ }^{13-15}$ soybean oil, ${ }^{30,31}$ or both. $5,6,12,17,23,24,26,27,29,32,33$ Keenan et al ${ }^{18}$ included a placebo of soybean oil combined with vitamin E and small amounts of DHA and EPA. Placebos in other studies contained sunflower oil alone ${ }^{21}$ or in combination with rapeseed and palm oils, ${ }^{9-11,19,28}$ olive oil, ${ }^{7,22}$ or liquid paraffin. ${ }^{25}$ One study included only the vitamins and minerals also included in the intervention supplement, minus DHA, EPA, and 5MTHF. ${ }^{2-4}$ Brei et al ${ }^{1}$ did not include a placebo, but the control group received general information about a healthy diet.

- The PCS by Huang et $\mathrm{al}^{16}$ examined omega-3 fatty acid supplementation dose as a continuous variable, but did not specify supplement composition.

\section{Timing of exposure}

- Studies included in this review assessed interventions/exposures during:

- Pregnancy alone: $11 \mathrm{RCTs}^{2-12,17-31}$ provided supplements from some point during the second trimester through delivery with one exception: Keenan et a ${ }^{18}$ provided supplements from week 16-20 of gestation and continued for 6 weeks (i.e., provided omega-3 fatty acid supplements only during second 
trimester). One PCS assessed omega-3 fatty acid supplement intake throughout pregnancy. ${ }^{16}$

- Both pregnancy and lactation: Three RCTs provided supplements from the second trimester of pregnancy through 3 months ${ }^{13-15,30,31}$ or 4 months postpartum. ${ }^{1}$

- Lactation alone: One RCT provided supplements from 5 days after birth through 4 months postpartum. ${ }^{32,33}$

\section{Outcome}

\section{Cognitive development}

- 12 RCTs assessed cognitive development, using measures of intelligence, attention, executive function, and information processing speed, as well as more general or comprehensive measures (see Table 2 for details). Of those 12 studies, 8 provided omega-3 fatty acid supplements during pregnancy alone, , $^{2,-7,9-12,19,22-27,29}$ 3 during both pregnancy and lactation, ${ }^{1,13-15,31}$ and 1 during lactation alone..$^{32,33}$

- The timing of cognitive development assessment in the children ranged from the neonatal period to 10 years, with the following distribution:

○ Birth to 12 months: 8 RCTs $5,12,13,22,24,25,29,33$

o $>12$ months to 2 years: 5 RCTs $^{6,9,10,19,24,27,31}$

$0>2$ years to 5 years: 7 RCTs $1,6,7,9,10,15,26,32,33$

o >5 years: 5 RCTs s $^{2,4,6,11,14,23}$

\section{Language development}

- Nine RCTs assessed language development (see Table 3). Of those 9, 7 provided omega-3 fatty acid supplements during pregnancy alone, ${ }^{6,7,9-11,18,19,22,23,25,26} 1$ during both pregnancy and lactation, ${ }^{1}$ and 1 during lactation alone. ${ }^{33}$

- The timing of language development assessment in the children ranged from 3 months to 12 years postpartum, with the following distributions:

○ Birth to 12 months: 4 RCTs $18,23,25,33$

- >12 months to 2 years: 3 RCTs $^{6,9,19,23}$

○ >2 years to 5 years: 6 RCTs $s^{1,6,7,10,26,33}$

○ >5 years: 3 RCTs ${ }^{11,22,23}$

\section{Motor development}

- Ten RCTs assessed motor development, including measures of gross and fine motor function (detailed in Table 4). Of those 10, 7 provided omega-3 fatty acid supplements during pregnancy alone, ${ }^{2,12,18,19,24-27} 2$ during both pregnancy and lactation, $1,30,31$ and 1 during lactation alone. ${ }^{32,33}$

- The timing of motor development assessment in the children ranged from 1 week to 5.5 years postpartum, with the following distributions:

- Birth to 12 months: 5 RCTs s $^{12,18,25,30,33}$

o >12 months to 18 months: 5 RCTs $19,24,27,31,33$

$0>18$ to $<2.5$ years: 0 RCTs

- 2.5 years to 7 years: 4 RCTs $s^{1,2,26,32,33}$

\section{Visual development}

- Six RCTs assessed visual development, including visual acuity (see Table 5). Of 
those 6,5 provided omega- 3 fatty acid supplements during pregnancy alone, ${ }^{17,21,24,28,29}$ and 1 during lactation alone..$^{32,33}$

- The timing of visual development assessment in the children ranged from the neonatal period to 5 years postpartum, with the following distributions:

- Birth to 6 months: 6 RCTs ${ }^{17,21,24,28,29,33}$

- >6 months to 12 months: 2 RCTs ${ }^{24,33}$

$0>12$ months to $<5$ years: 0 RCTs

- 5 years: $1 \mathrm{RCTs}^{32}$

\section{Social-emotional development}

- Eight RCTs assessed social-emotional development (Table 6). Of those 8, 7 provided omega-3 fatty acid supplements during pregnancy alone ${ }^{6,7,10-12,18,19,22,25-27}$ and 1 during both pregnancy and lactation. ${ }^{1}$

- The timing of social-emotional development assessment in the children ranged from 1 week to 12 years postpartum, with the following distributions:

- Birth to 12 months: 3 RCTs ${ }^{12,18,25}$

o >12 months to 2 years: 2 RCTs ${ }^{19,27}$

$0>2$ years to 5 years: 5 RCTs $1,6,7,10,26$

○ >5 years: 3 RCTs $s^{5,11,22}$

\section{Academic performance}

- One RCT assessed academic performance, including reading, spelling, and math computation at age 7 years among children of mothers who participated in an intervention during pregnancy alone (Table 7). ${ }^{11}$

\section{Anxiety and Depression}

- No studies meeting the inclusion criteria assessed anxiety or depression in children.

\section{$A D D / A D H D$}

- One RCT assessed hyperactivity disorders at 4 years ${ }^{10}$ and ADHD at age 7 years ${ }^{11}$ among children of mothers who participated in an intervention during pregnancy alone (Table 7).

\section{Autism spectrum disorder}

- Two studies assessed the risk of autism spectrum disorder in children (Table 7). One study was an RCT that supplemented mothers during pregnancy alone and assessed children at 4 years. ${ }^{10}$ The other study was a PCS that assessed children at 36 months. ${ }^{16}$

\section{Evidence synthesis}

The 33 articles from 16 studies, including 15 RCTs and 1 PCS, provided a substantial body of evidence to examine the relationship between omega-3 fatty acid supplementation during pregnancy and/or lactation and developmental milestones in the child. Among these studies, however, the time period of both the intervention/exposure and the outcome assessment varied widely. Furthermore, heterogeneity in the developmental domains assessed, as well as in the measures used to evaluate child performance in each of those domains, limited the ability to compare results across studies. Many of the assessment 
tools administered in the included studies are widely used and have been validated for use in similar populations, including the Bayley Scales of Infant Development, the Wechsler scales of intelligence (WISC, WPPSI, and WASI), the Kaufman Assessment Battery for Children, and the Fagan Test of Infant Intelligence. However, the validity and reliability of any measure of neurobehavioral development depend on multiple factors, such as the appropriate administration of the assessment, the training of study personnel who administer the assessment, and the quality of data processing and statistical analysis; this detailed information was not provided in all studies. Further, whether an assessment is able to detect the effects of a nutrition intervention depends on its sensitivity to the functions, brain areas that are affected by the nutrient of interest and timing of assessment. This may be particularly relevant in populations without overt nutrient deficiencies, as the effects of interventions are smaller and thus require greater sensitivity of neurobehavioral assessments. Therefore, assessments targeting multiple cognitive functions, even within a single population may not produce consistent results.

Due to concerns about sample size, multiple testing without adjustment for multiple comparisons, and interpretability of interactions, only main effects were considered in this review. Key confounders were considered in this body of evidence. However, it was less of a concern because most of the studies included in this body of evidence were RCTs. Publication bias is always a consideration, however, it is not a serious concern for this body of evidence because 3 studies reported only non-significant findings ${ }^{1-4,16}$ while the remaining studies report a mix of significant and non-significant results.

\section{Cognitive development}

\section{Supplementation during pregnancy alone:}

Summary:

Five of 8 studies found a statistically significant, favorable effect of supplementation on at least one measure of child cognitive development (detailed in Table 2). ${ }^{5-7,10-12,19,26}$ One study found a statistically significant, unfavorable effect of supplementation on a single measure of child cognitive development. Specifically, Makrides et $\mathrm{al}^{10}$ and Gould et al ${ }^{11}$ found that children of mothers who consumed omega-3 fatty acid supplements during pregnancy scored less favorably on a parent-reported measure of executive function at age 4 years and 7 years. All 8 RCTs also found no effect of treatment on at least one measure of cognitive development in children ages 1 week to 8.5 years. ${ }^{2-7,10-12,19,22-27,29}$

When examining the totality of the evidence a general pattern emerged of more favorable, as opposed to unfavorable, outcomes of cognitive development among children of women who consumed omega-3 fatty acid supplements during pregnancy. However, a number of measures across all studies showed no statistically significant treatment effect of omega-3 fatty acid supplementation on cognitive development in the child. No notable differences in the timing of the intervention/exposure, the dose or composition of omega-3 fatty acid supplements, nor in the timing or method of outcome assessment, could explain the mixed results. 


\section{Assessment of the evidence ${ }^{v}$ :}

The following conclusion statement was based on 8 RCTs and was graded "limited."

"Limited evidence suggests that omega-3 fatty acid supplementation during pregnancy may result in favorable cognitive development in the child."

As outlined and described below, the body of evidence examining omega-3 fatty acid supplementation during pregnancy and cognitive development in the child was assessed for the following elements used when grading the strength of the evidence (see also Table 8).

- Risk of bias was graded as strong for the RCTs included in this body of evidence. Overall, the RCTs included in this body of evidence had strong designs, were well conducted, and had few major flaws, resulting in overall low risk of bias based on randomization, deviations from intended interventions, and outcome measurement for all studies. The few concerns noted were unlikely to alter the results, and are described below:

- Two studies had probable differences in reasons for attrition between intervention and control groups, resulting in increased risk of bias due to missing outcome data. ${ }^{5,7,22}$

- Generally, the included studies had some risk of bias due to selection of the reported results. Few studies published pre-registered analysis plans, and thus it was unclear whether the reported analyses were selected based on the outcome. However, given that the reported domains were generally consistent with pre-registered protocols and that all of the studies reported at least one nonstatistically significant result, the risk was judged to be moderate.

- One article reported analyses that were consistent with the published protocol, ${ }^{11}$ but another study reported only some of the analyses outlined in the prepublished analysis plan. ${ }^{24}$ Further, Catena et al ${ }^{4}$ excluded children with $>50$ percent error on the Attention Network Task, but did not report the comparison of analyses with and without those data.

- Consistency was graded limited. Findings were mixed both within and between studies. These inconsistencies could not be explained by methodological differences, as there were no obvious differences in the specific timing or duration of the intervention, the composition or dose of the omega-3 fatty acid supplements or placebos, or in the timing or measurement tool for the outcome assessment that could explain the heterogeneity of the results. However, the wide variety in the timing of outcome assessments made it difficult to compare results across studies.

- Directness was graded as strong for the RCTs in this body of evidence. All studies were designed to examine an intervention of omega-3 fatty acid supplementation during pregnancy and with one exception, ${ }^{7,22}$ the primary or pre-registered secondary outcome was cognitive development in the child.

\footnotetext{
${ }^{v}$ A detailed description of the methodology used for grading the strength of the evidence is available on the NESR website: https://nesr.usda.gov/2020-dietary-guidelines-advisory-committee-systematicreviews and in Part $\mathrm{C}$ of the following reference: Dietary Guidelines Advisory Committee. 2020. Scientific Report of the 2020 Dietary Guidelines Advisory Committee: Advisory Report to the Secretary of Agriculture and the Secretary of Health and Human Services. U.S. Department of Agriculture, Agricultural Research Service, Washington, DC.
} 
- Precision was graded as moderate for the studies. There were an adequate number of studies to investigate the relationship between omega-3 supplementation during pregnancy and cognitive development in children. Two studies had substantial sample sizes that, based on estimated effect sizes in similar studies, were likely sufficient to examine this relationship, especially at earlier outcome assessments. ${ }^{10,11,19,26,27}$ Two studies reported power calculations suggesting that the studies were sufficiently powered. ${ }^{5,6,25}$ Four studies generally did not report power calculations and it is unclear whether the final sample size was sufficiently powered. ${ }^{7,12,22-24}$ In addition to power, number of studies that were included in the body of evidence and variability within and across studies were considered while grading precision. Overall, none of the studies unduly influenced the findings of this systematic review and removing a single study from this body of evidence would not likely change the conclusions.

- Generalizability was graded as moderate for this body of evidence. Two studies were conducted in the United States and both were from the same research group. 5,6,12 Minority women were generally underrepresented in this body of evidence. Two studies did not provide any information regarding race/ethnicity, ${ }^{2-}$ 4,10,11,19 and 2 studies recruited primarily White participants. ${ }^{7,22-24}$ However, the remaining 4 studies recruited primarily non-White participants, including the U.S.based studies. ${ }^{5,6,12,25-27}$ Regarding socioeconomic status, the studies mostly included women with post-secondary education. Participants were primarily adult women and none of the studies focused on adolescent mothers. For these reasons, the findings from this systematic review are somewhat applicable to the general U.S. population.

\section{Supplementation during pregnancy and lactation:}

\section{Summary:}

Three RCTs examined the effects of omega- 3 fatty acid supplementation during both pregnancy and lactation on cognitive development in the child (ages 6 months to 7 years) (Table 2). ${ }^{1,13-15,31}$ One study found a statistically significant, favorable effect of supplementation on one measure of intelligence in the child at age 4 years. ${ }^{15}$ All 3 RCTs found no treatment effect on at least one measure of cognitive development from ages 6 months to 7 years.

\section{Assessment of the evidence:}

Given the mixed results and the small number of studies, risk of bias due to deviations from intended interventions because of large attrition rates (Table 8), and limited information on the generalizability of results to the general U.S. population, insufficient evidence existed to determine the relationship between omega-3 fatty acid supplementation during both pregnancy and lactation and cognitive development in the child. Therefore, the body of evidence was rated 'grade not assignable.'

\section{Supplementation during lactation alone:}

\section{Summary:}

One RCT examined the effects of omega- 3 fatty acid supplementation during lactation alone on cognitive development in the child (ages 2.5 years to 5 years) (Table 2). ${ }^{32,33}$ Jensen et $\mathrm{a}^{32,33}$ reported a statistically significant, favorable effect of supplementation on one measure of sustained attention in the child at age 5 years, as well as no association 
with multiple measures of cognitive development at ages 12 months, 2.5 years, and 5 years.

Assessment of the evidence:

The entire body of evidence consisted of a single study with concerns regarding statistical power to detect effects in these secondary outcomes, risk of bias due to outcome measurement and deviations from the intended intervention (Table 8), and a sample that may not reflect the diversity of the general U.S. population. Therefore, insufficient evidence existed to determine the relationship between omega- 3 fatty acid supplementation during lactation alone and cognitive development in the child, and the body of evidence was rated 'grade not assignable.' 
Table 2. Description of evidence on relationship between omega-3 fatty acid supplementation and cognitive development ${ }^{\mathrm{i}}$

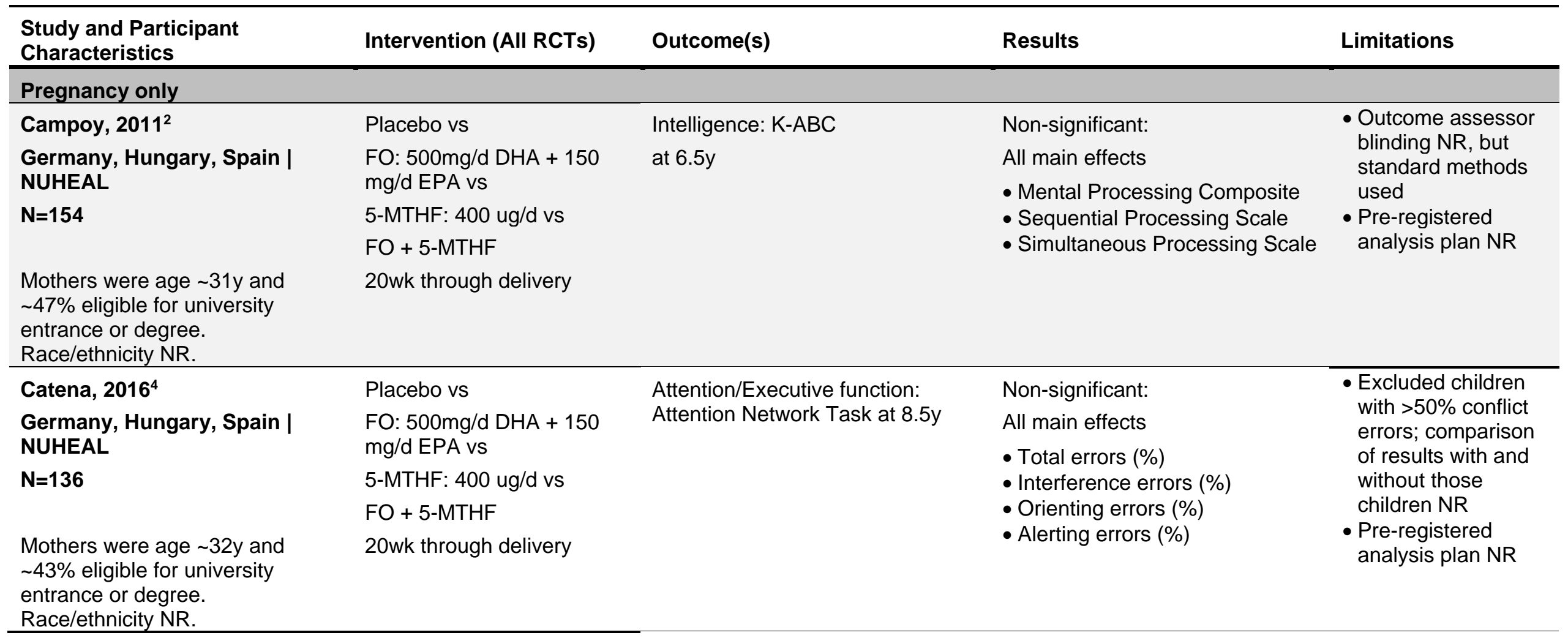

vi ABR: Auditory brainstem response; Adj: adjusted; ARA: arachidonic acid; ASQ: Ages and Stages Questionnaire; BRIEF: Behavior Rating Inventory of Executive Function-Preschool; BSID: Bayley Scales of Infant Development; CELF: Clinical Evaluation of Language Fundamentals; CI: confidence interval; DAS: Differential Ability Scales; DHA: docosahexaenoic acid; DOMInO: DHA to Optimize Mother Infant Outcome; EPA: eicosapentaenoic acid; FO: fish oil; FTII: Fagan Test of Infant Intelligence; GMDS: Griffiths Mental Development Scales; INFAT: The Impact of the Nutritional Fatty Acids During Pregnancy and Lactation for Early Human Adipose Tissue Development; IQ: intellignce quotient; ISI: interstimuli interval; K-ABC: Kaufman Assessment Battery for Children; KCPT: Kiddie Continuous Performance Test; KUDOS: Kansas University DHA Outcomes Study; MSCA: McCarthy Scales of Children's Abilities; MTHF: methyl tetrahydrofolate; NBAS: Neonatal Behavioral Assessment Scale; NR: not reported; NUHEAL: Nutraceuticals for a Healthier Life; POSGRAD: Prenatal Omega 3 Supplementation on child Growth and Development; RAVLT: Rey Auditory Verbal Learning Test; RCT: randomized controlled trial; SD: standard deviation; SE: standard error; RT: reaction time; TEACh: Test of Everyday Attention for Children; WASI: Wechsler Abbreviated Scale of Intelligence; WISC: Wechsler Intelligence Scale for Children; WMIC: working memory and inhibitory control; WPPSI: Wechsler Primary and Preschool Scale of Intelligence 


\begin{tabular}{|c|c|c|c|c|}
\hline $\begin{array}{l}\text { Study and Participant } \\
\text { Characteristics }\end{array}$ & Intervention (All RCTs) & Outcome(s) & Results & Limitations \\
\hline $\begin{array}{l}\text { Catena, } 2019^{3} \\
\text { Spain | NUHEAL } \\
\text { N=74 } \\
\text { Mothers were age } \sim 31 \text { y at } \\
\text { delivery, } 76 \% \text { medium to high } \\
\text { SES, and } \sim 32 \% \text { completed } \\
\text { secondary education or higher. } \\
\text { Race/Ethnicity: } 100 \% \text { White } \\
\text { children. }\end{array}$ & $\begin{array}{l}\text { Placebo vs } \\
\text { FO: } 500 \mathrm{mg} / \mathrm{d} \text { DHA + } 150 \\
\text { mg/d EPA vs } \\
5-\mathrm{MTHF}: 400 \mathrm{ug} / \mathrm{d} \text { vs } \\
\text { FO + 5-MTHF } \\
\text { 20wk through delivery }\end{array}$ & $\begin{array}{l}\text { Intelligence: K-ABC-II } \\
\text { at } 6.6 \mathrm{y}\end{array}$ & $\begin{array}{l}\text { Non-significant: } \\
\text { All main effects } \\
\text { - Mental Processing Index }\end{array}$ & $\begin{array}{l}\text { - Outcome assessor } \\
\text { blinding NR, but } \\
\text { standard methods } \\
\text { used } \\
\text { - Pre-registered } \\
\text { analysis plan NR }\end{array}$ \\
\hline $\begin{array}{l}\text { Colombo, } 2016^{5} \\
\text { USA | KUDOS } \\
\text { N=156 } \\
\text { Mothers were age 26y at } \\
\text { enrollment, with mean income } \\
<\$ 46 \text { K and } \sim 14 y \text { education. } \\
\text { Race/Ethnicity: 6\% Hispanic, 31\% } \\
\text { Black. }\end{array}$ & $\begin{array}{l}600 \mathrm{mg} / \mathrm{d} \text { DHA vs placebo } \\
\text { (corn and soybean oils) } \\
\sim 14.5 \mathrm{wk} \text { through delivery }\end{array}$ & $\begin{array}{l}\text { Visual learning: Visual habituation } \\
\text { task with simultaneous heart rate } \\
\text { at } 4 \mathrm{mo}, 6 \mathrm{mo}, 9 \mathrm{mo}\end{array}$ & $\begin{array}{l}\text { Significant: } \\
\text { Favors Intervention } \\
\text { Attrition due to fussiness } \\
\text { Overall, } \mathrm{P}<0.01 \\
\text { Control: } \mathrm{N}=64 \text {, Intervention: } \\
\mathrm{N}=47 \\
\text { at } 6 \text { mo, } \mathrm{P}<0.001 \\
\text { Control: } \mathrm{N}=23 \text {, Intervention: } \mathrm{N}=6 \\
\text { at } 9 \text { mo, } \mathrm{P}<0.05 \\
\text { Control: } \mathrm{N}=22 \text {, Intervention: } \\
\mathrm{N}=14 \\
\text { Non-significant: } \\
\text { All other main effects } \\
\text { - Peak look duration } \\
\text { - Looks to habituation, } \mathrm{P}=0.056 \\
\text { o Faster habituation in } \mathrm{DHA} \text { vs } \\
\text { placebo }\end{array}$ & $\begin{array}{l}\text { - Proportions and } \\
\text { reasons for } \\
\text { missingness differ, } \\
\text { seemingly more } \\
\text { dropout in placebo } \\
\text { group } \\
\text { - Major differences in } \\
\text { those followed up } \\
\text { and not followed up } \\
\text { - Pre-registered data } \\
\text { analysis plan NR }\end{array}$ \\
\hline
\end{tabular}




\begin{tabular}{|c|c|c|c|c|}
\hline $\begin{array}{l}\text { Study and Participant } \\
\text { Characteristics }\end{array}$ & Intervention (All RCTs) & Outcome(s) & Results & Limitations \\
\hline \multirow[t]{6}{*}{$\begin{array}{l}\text { Colombo, } 2019^{6} \\
\text { USA | KUDOS } \\
\mathrm{N}=161 \\
\text { Mothers were age } \sim 26 y \text { at } \\
\text { enrollment, with mean income } \\
<\$ 46 \mathrm{~K} \text { and } \sim 14 \mathrm{y} \text { education. } \\
\text { Race/Ethnicity: } 6 \% \text { Hispanic, } 31 \% \\
\text { Black. }\end{array}$} & $\begin{array}{l}600 \mathrm{mg} / \mathrm{d} \text { DHA vs placebo } \\
\text { (corn and soybean oils) } \\
\sim 14.5 \mathrm{wk} \text { through delivery }\end{array}$ & $\begin{array}{l}\text { BSID-II } \\
\text { at } 18 \mathrm{mo}\end{array}$ & $\begin{array}{l}\text { Non-significant: } \\
\text { All main effects } \\
\text { - Mental Development Index } \\
\text { - Psychomotor Development } \\
\text { Index } \\
\text { - Behavior Rating Scale total }\end{array}$ & $\begin{array}{l}\text { - (See Colombo, } \\
\text { 2016) } \\
\text { - More outcomes } \\
\text { reported in the } \\
\text { paper than on the } \\
\text { clinical trials } \\
\text { registry. } \\
\text { - Pre-registered data } \\
\text { analysis plan NR }\end{array}$ \\
\hline & & $\begin{array}{l}\text { WPPSI-III } \\
\text { at } 36,48,72 \mathrm{mo}\end{array}$ & $\begin{array}{l}\text { Non-significant: } \\
\text { All main effects } \\
\text { - Verbal IQ } \\
\text { - Performance IQ } \\
\text { - Processing Speed } \\
\text { - Full Scale IQ }\end{array}$ & \\
\hline & & $\begin{array}{l}\text { Executive function: Willatts } \\
\text { problem-solving task } \\
\text { at } 10 \mathrm{mo}\end{array}$ & $\begin{array}{l}\text { Non-significant: } \\
\text { All main effects } \\
\text { - Total score }\end{array}$ & \\
\hline & & $\begin{array}{l}\text { Executive function: Delayed } \\
\text { Response spatial memory task } \\
\text { at } 24 \text { and } 30 \mathrm{mo}\end{array}$ & $\begin{array}{l}\text { Significant: } \\
\text { Favors intervention } \\
\text { at } 24 \text { mo } \\
\text { Initial trials, } P<0.05 \\
\text { Effect size }(d): 0.063\end{array}$ & . \\
\hline & & & $\begin{array}{l}\text { Reversal trials, } P<0.05 \\
\text { Effect size }(d): 0.278\end{array}$ & \\
\hline & & & $\begin{array}{l}\text { at } 30 \text { mo } \\
\text { Initial trials, } P<0.05 \\
\text { Effect size }(d): 0.128\end{array}$ & \\
\hline
\end{tabular}




\begin{tabular}{|c|c|c|c|c|}
\hline \multirow[t]{4}{*}{$\begin{array}{l}\text { Study and Participant } \\
\text { Characteristics }\end{array}$} & Intervention (All RCTs) & Outcome(s) & Results & Limitations \\
\hline & & & $\begin{array}{l}\text { Reversal trials, } P<0.05 \\
\text { Effect size }(d): 0.340\end{array}$ & \\
\hline & & $\begin{array}{l}\text { Executive function: Dimensional } \\
\text { Change Card Sort task and Stroop } \\
\text { task } \\
\text { at } 36,42,48,60 \mathrm{mo}\end{array}$ & $\begin{array}{l}\text { Non-significant: } \\
\text { All main effects } \\
\text { Dimensional Change Card } \\
\text { - Prestwich total } \\
\text { - Postswitch total } \\
\text { - Percent passing } \\
\text { Stroop task } \\
\text { - Total score }\end{array}$ & \\
\hline & & $\begin{array}{l}\text { Executive function: Tower of } \\
\text { Hanoi } \\
\text { at } 60 \text { and } 72 \mathrm{mo}\end{array}$ & $\begin{array}{l}\text { Non-significant: } \\
\text { All main effects } \\
\text { - Max steps } \\
\text { - Efficiency }\end{array}$ & \\
\hline $\begin{array}{l}\text { Dunstan, } \mathbf{2 0 0 8}^{\mathbf{7}} \\
\text { Australia } \\
\mathrm{N}=\mathbf{7 2} \\
\text { Mothers were age } \sim 32 \mathrm{y} \text { at } \\
\text { enrollment and } \sim 73 \% \text { completed } \\
\geq 12 \mathrm{y} \text { education. Race/Ethnicity: } \\
100 \% \text { White. }\end{array}$ & $\begin{array}{l}2.2 \mathrm{~g} / \mathrm{d} \mathrm{DHA}+1.1 \mathrm{~g} / \mathrm{d} \text { EPA } \\
\text { vs placebo (olive oil) } \\
\text { 20wk through delivery }\end{array}$ & $\begin{array}{l}\text { GMDS } \\
\text { at } 2.5 y\end{array}$ & $\begin{array}{l}\text { Significant: } \\
\text { Favors Intervention } \\
\text { Eye and hand coordination } \\
\text { subscale quotient } \\
\mathrm{P}=0.021 \\
\text { Control (Mean } \pm \mathrm{SD} \text { ): } 108.0 \pm 11.3 \\
\text { Intervention: } 114.0 \pm 10.2 \\
\text { Non-significant: } \\
\text { All other main effects } \\
\text { - Locomotor } \\
\text { - Personal social } \\
\text { - Speech and hearing } \\
\text { - Performance }\end{array}$ & $\begin{array}{l}\text { - Probable } \\
\text { differences in } \\
\text { reasons for attrition } \\
\text { - No power } \\
\text { calculation for } \\
\text { neurobehavioral } \\
\text { results } \\
\text { - Pre-registered data } \\
\text { analysis plan NR }\end{array}$ \\
\hline
\end{tabular}




\begin{tabular}{|c|c|c|c|c|}
\hline $\begin{array}{l}\text { Study and Participant } \\
\text { Characteristics }\end{array}$ & Intervention (All RCTs) & Outcome(s) & Results & Limitations \\
\hline & & & $\begin{array}{l}\text { - Practical reasoning } \\
\text { - General quotient score }\end{array}$ & \\
\hline \multirow{13}{*}{$\begin{array}{l}\text { Gould, 2014 } \\
\text { Australia | DOMInO } \\
\text { N=158 } \\
\text { Mothers were age } \sim 30 \text { y at } \\
\text { enrollment and } \sim 65 \% \text { completed } \\
\text { secondary education. } \\
\text { Race/ethnicity NR. }\end{array}$} & \multirow{4}{*}{$\begin{array}{l}800 \mathrm{mg} / \mathrm{d} \text { DHA }+100 \mathrm{mg} / \mathrm{d} \\
\text { EPA vs Vegetable oil } \\
\text { (rapeseed, } \\
\text { sunflower, and palm) } \\
\text { placebo } \\
18-21 \text { wk through delivery }\end{array}$} & \multirow{4}{*}{$\begin{array}{l}\text { Attention: Sustained attention } \\
\text { (Single Object task) } \\
\text { at } 27 \pm 2 \mathrm{mo}\end{array}$} & \multirow{4}{*}{$\begin{array}{l}\text { Non-significant: } \\
\text { All main effects } \\
\text { - Total duration of time spent } \\
\text { looking at the toy } \\
\text { - Percentage of time spent } \\
\text { looking at the toy } \\
\text { - Average length of look at the } \\
\text { toy } \\
\text { - No. of looks at the toy } \\
\text { - No. of times looked away from } \\
\text { the toy }\end{array}$} & \multirow{4}{*}{$\begin{array}{l}\text { - Power calculation } \\
\text { NR } \\
\text { - Pre-registered } \\
\text { analysis plan NR }\end{array}$} \\
\hline & & & & \\
\hline & & & & \\
\hline & & & & \\
\hline & & \multirow{2}{*}{$\begin{array}{l}\text { Attention: Sustained attention } \\
\text { (Multiple Object task) }\end{array}$} & Significant: & \\
\hline & & & Favors intervention & \\
\hline & & \multirow[t]{4}{*}{ at $27 \pm 2 \mathrm{mo}$} & $\begin{array}{l}\text { No. of times looked away from } \\
\text { toys }\end{array}$ & \\
\hline & & & Adj $P=0.03$ & \\
\hline & & & Ref: Control & \\
\hline & & & $\begin{array}{l}\text { Mean Difference: }-2.0,95 \% \mathrm{Cl} \text { : (- } \\
3.9,-0.2)\end{array}$ & \\
\hline & & & Non-significant: & \\
\hline & & & All other main effects & \\
\hline & & & $\begin{array}{l}\text { - No. of times shifted looks } \\
\text { between toys } \\
\text { - Total duration of time looking at } \\
\text { toys } \\
\text { - Percentage of time spent } \\
\text { looking at toys }\end{array}$ & \\
\hline
\end{tabular}




\begin{tabular}{|c|c|c|c|c|}
\hline \multirow[t]{4}{*}{$\begin{array}{l}\text { Study and Participant } \\
\text { Characteristics }\end{array}$} & Intervention (All RCTs) & Outcome(s) & Results & Limitations \\
\hline & & & $\begin{array}{l}\text { - Average length of a look at a } \\
\text { toy }\end{array}$ & \\
\hline & & $\begin{array}{l}\text { Attention: Distractibility (Multiple } \\
\text { Object with distractor task) }\end{array}$ & Non-significant: & \\
\hline & & at $27 \pm 2 \mathrm{mo}$ & $\begin{array}{l}\text { - Average latency to turn to the } \\
\text { distractor when attention was } \\
\text { focused } \\
\text { - Percentage of times distracted } \\
\text { when focused } \\
\text { - Average latency to look to the } \\
\text { distractor when attention was } \\
\text { casual } \\
\text { - Percentage of times distracted } \\
\text { when attention was casual } \\
\text { - Total duration of time spent } \\
\text { looking at the distractor when } \\
\text { the distractor was on } \\
\text { - Total duration of time spent } \\
\text { looking at the distractor when } \\
\text { the distractor was off }\end{array}$ & \\
\hline & & WMIC: A-not-B task: & Significant: & \\
\hline & & at $27 \pm 2 \mathrm{mo}$ & Favors intervention & \\
\hline & & & $\begin{array}{l}\text { Average accuracy during training } \\
\text { trials }\end{array}$ & \\
\hline & & & Adj $P=0.05$ & \\
\hline & & & Ref: Control & \\
\hline & & & $\begin{array}{l}\text { Adj Mean Difference (mm): 14.4, } \\
\text { 95\% Cl: }(20.2,29.1)\end{array}$ & \\
\hline & & & Non-significant: & \\
\hline & & & All other main effects & \\
\hline & & & $\begin{array}{l}\text { - Average accuracy during test } \\
\text { trials }\end{array}$ & \\
\hline
\end{tabular}




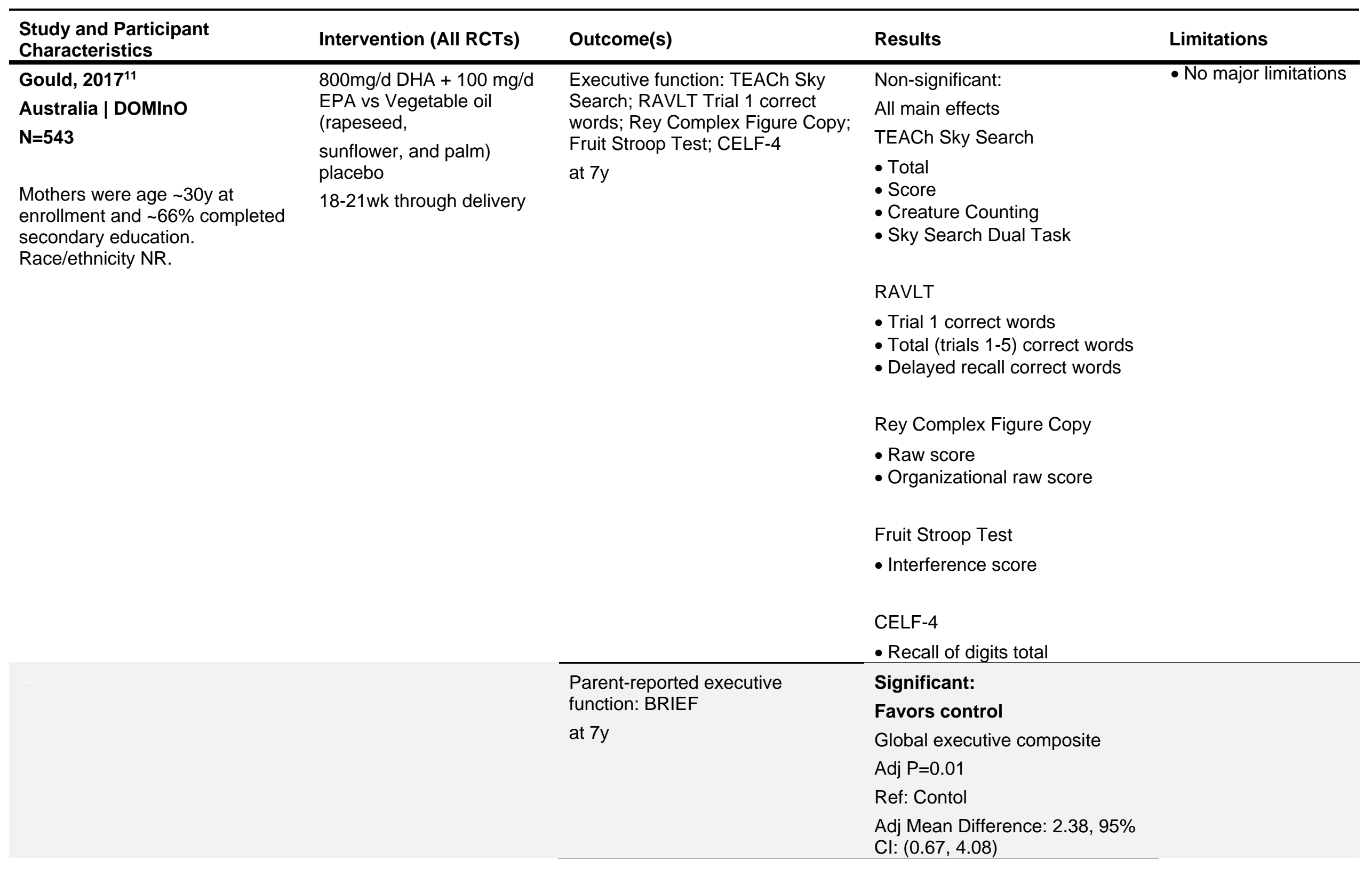




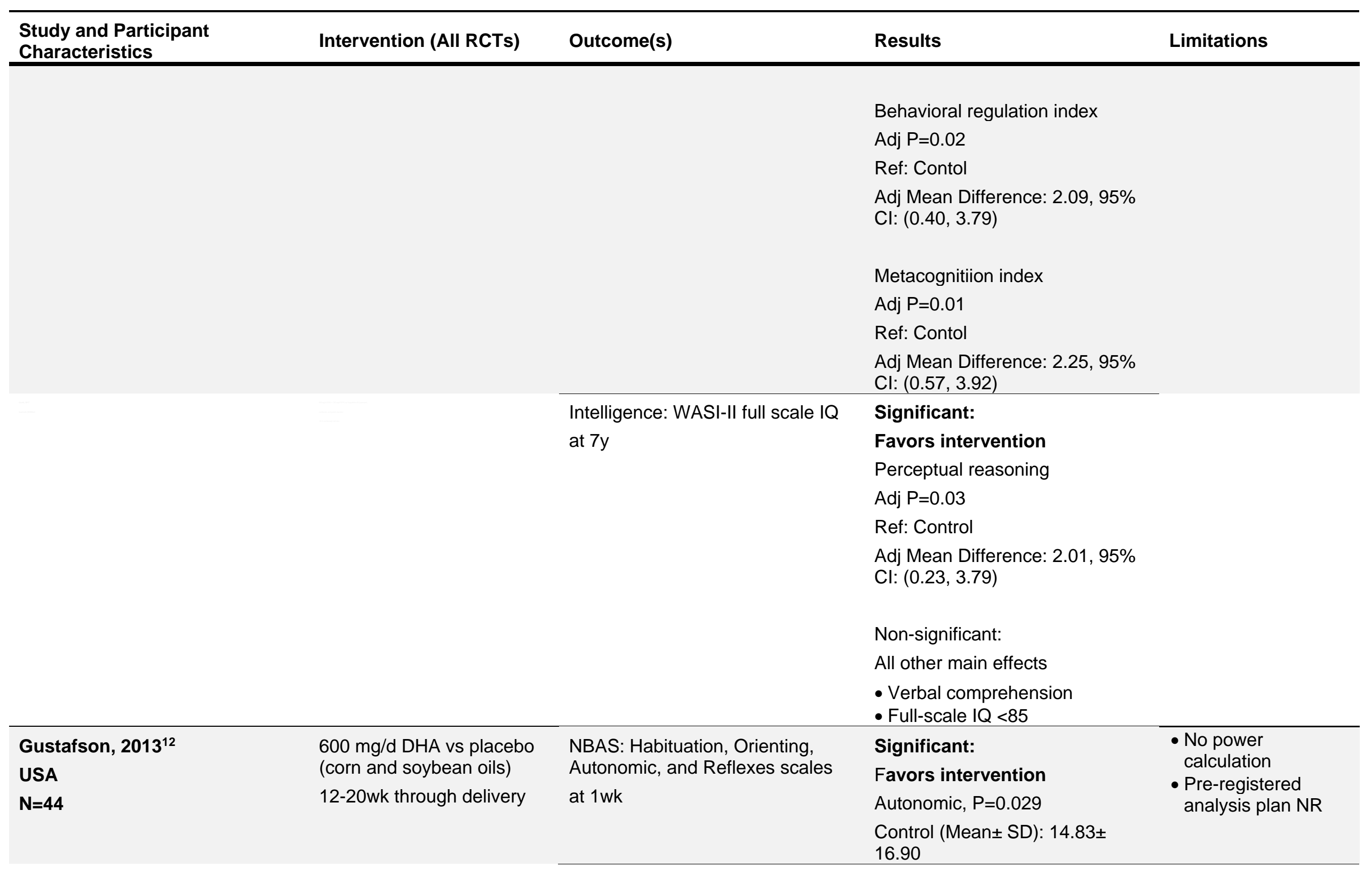




\begin{tabular}{|c|c|c|c|c|}
\hline $\begin{array}{l}\text { Study and Participant } \\
\text { Characteristics }\end{array}$ & Intervention (All RCTs) & Outcome(s) & Results & Limitations \\
\hline $\begin{array}{l}\text { Mothers were age } \sim 26 y \text { at } \\
\text { enrollment and completed } \sim 14 y \\
\text { education. Race/Ethnicity: } 37.3 \% \\
\text { Black, } 46.3 \% \text { White, } 13.4 \% \\
\text { Hispanic, 3\% Asian. }\end{array}$ & & & $\begin{array}{l}\text { Intervention: } 18.13 \pm 14.48 \\
\text { Non-significant: } \\
\text { All other main effects } \\
\text { - Habituation } \\
\text { - Orienting } \\
\text { - Reflexes }\end{array}$ & \\
\hline $\begin{array}{l}\text { Makrides, } 2010^{19} \\
\text { Australia | DOMInO } \\
\mathrm{N}=694 \\
\text { Mothers were age } ~ 29 y \text { at } \\
\text { enrollment and } \sim 68 \% \text { completed } \\
\text { more than secondary education. } \\
\text { Race/ethnicity NR. }\end{array}$ & $\begin{array}{l}800 \mathrm{mg} / \mathrm{d} \mathrm{DHA}+100 \mathrm{mg} / \mathrm{d} \\
\text { EPA vs Vegetable oil } \\
\text { (rapeseed, } \\
\text { sunflower, and palm) } \\
\text { placebo } \\
18-21 \text { wk through delivery }\end{array}$ & $\begin{array}{l}\text { BSID-III: Cognitive Scale, } \\
\text { continuous, accelerated, and } \\
\text { delayed } \\
\text { at } 18 \mathrm{mo}\end{array}$ & $\begin{array}{l}\text { Significant: } \\
\text { Favors intervention } \\
\text { Cognitive Standardized Score, } \\
\text { Continuous <85, Adj P=0.007 } \\
\text { Ref: Control } \\
\text { Adj RR: } 0.41,95 \% \mathrm{Cl}:(0.22 \text {, } \\
0.78) \\
\text { Non-significant: } \\
\text { All other main effects } \\
\text { - Cognitive Standardized Score, } \\
\text { Delayed } \\
\text { - Cognitive Standardized Score, } \\
\text { Accelerated }\end{array}$ & $\begin{array}{l}\text { - Pre-registered } \\
\text { analysis plan NR }\end{array}$ \\
\hline $\begin{array}{l}\text { Makrides, } \mathbf{2 0 1 4}^{20} \\
\text { Australia | DOMInO } \\
\mathrm{N}=646 \\
\text { Mothers were age } \sim 29 \mathrm{y} \text { at } \\
\text { enrollment and } \sim 68 \% \text { completed } \\
\text { more than secondary education. }\end{array}$ & $\begin{array}{l}800 \mathrm{mg} / \mathrm{d} \text { DHA }+100 \mathrm{mg} / \mathrm{d} \\
\text { EPA vs Vegetable oil } \\
\text { (rapeseed, } \\
\text { sunflower, and palm) } \\
\text { placebo } \\
18-21 \text { wk through delivery }\end{array}$ & $\begin{array}{l}\text { DAS-II: General Conceptual } \\
\text { Ability, Non-verbal Reasoning, } \\
\text { Verbal Reasoning, and Spatial } \\
\text { Scales } \\
\text { at } 4 y\end{array}$ & $\begin{array}{l}\text { Non-significant: } \\
\text { All main effects } \\
\text { - General Conceptual Ability } \\
\text { Scale } \\
\text { - Non-verbal Reasoning Scale } \\
\text { - Verbal Reasoning Scale } \\
\text { - Spatial Scale }\end{array}$ & $\begin{array}{l}\text { - Pre-registered } \\
\text { analysis plan NR }\end{array}$ \\
\hline & & $\begin{array}{l}\text { Executive function: DAS II: Day- } \\
\text { night Stroop }\end{array}$ & Non-significant: & \\
\hline
\end{tabular}




\begin{tabular}{|c|c|c|c|c|}
\hline \multirow[t]{18}{*}{$\begin{array}{l}\text { Study and Participant } \\
\text { Characteristics }\end{array}$} & Intervention (All RCTs) & Outcome(s) & Results & Limitations \\
\hline & & at $4 y$ & All main effects & \\
\hline & & & DAS II & \\
\hline & & & $\begin{array}{l}\text { - Recall of Digits Forwards } \\
\text { - Recognition of Pictures }\end{array}$ & \\
\hline & & & Day-night Stroop & \\
\hline & & Parent-reported executive & Significant: & \\
\hline & & function: BRIEF & Favors control & \\
\hline & & at $4 y$ & Emergent Meta-Cognition Index & \\
\hline & & & Adj $P=0.03$ & \\
\hline & & & Ref: Contol & \\
\hline & & & $\begin{array}{l}\text { Adj Mean Difference: } 1.52,95 \% \\
\text { CI: }(0.11,2.92)\end{array}$ & \\
\hline & & & Plan/Organize Scale & \\
\hline & & & Adj $P=0.02$ & \\
\hline & & & Ref: Contol & \\
\hline & & & $\begin{array}{l}\text { Adj Mean Difference: } 1.54,95 \% \\
\text { Cl: }(0.21,2.87)\end{array}$ & \\
\hline & & & Non-significant: & \\
\hline & & & All other main effects & \\
\hline & & & $\begin{array}{l}\text { - Global Executive Composite } \\
\text { - Inhibitory Self-Control index } \\
\text { - Flexibility Index } \\
\text { - Inhibition Scale } \\
\text { - Shift Scale } \\
\text { - Emotional Control Scale } \\
\text { - Working Memory Scale }\end{array}$ & \\
\hline
\end{tabular}




\begin{tabular}{|c|c|c|c|c|}
\hline $\begin{array}{l}\text { Study and Participant } \\
\text { Characteristics }\end{array}$ & Intervention (All RCTs) & Outcome(s) & Results & Limitations \\
\hline $\begin{array}{l}\text { Meldrum, } 2015^{22} \\
\text { Australia } \\
\mathbf{N}=48 \\
\text { Mothers were age } \sim 32 y \text { at } \\
\text { enrollment and } \sim 73 \% \text { completed } \\
\geq 12 y \text { education. Race/Ethnicity: } \\
100 \% \text { White. }\end{array}$ & $\begin{array}{l}2.2 \mathrm{~g} / \mathrm{d} \mathrm{DHA}+1.1 \mathrm{~g} / \mathrm{d} \mathrm{EPA} \\
\text { vs placebo (olive oil) } \\
20 \mathrm{wk} \text { through delivery }\end{array}$ & $\begin{array}{l}\text { WISC-IV } \\
\text { Beery-Buktenica Developmental } \\
\text { Test of Visual-Motor Integration } \\
\text { at } 12 y\end{array}$ & $\begin{array}{l}\text { Non-significant: } \\
\text { All main effects } \\
\text { WISC-IV } \\
\text { - Full Scale IQ } \\
\text { - Verbal Comprehension } \\
\text { - Perceptual Reasoning } \\
\text { - Working Memory } \\
\text { - Processing Speed } \\
\text { Beery-Buktenica } \\
\text { - Standard Score } \\
\text { - Percentiles }\end{array}$ & $\begin{array}{l}\text { - Among those } \\
\text { followed to } 12 y \text {, } \\
\text { birth weight differed } \\
\text { by treatment group } \\
\text { - Possible } \\
\text { differences in } \\
\text { reasons for attrition } \\
\text { - No power } \\
\text { calculation, Likely } \\
\text { under-powered }\end{array}$ \\
\hline $\begin{array}{l}\text { Mulder, } \mathbf{2 0 1 3}^{24} \\
\text { Canada } \\
\mathrm{N}=154 \\
\text { Mothers were age } \sim 33 \mathrm{y} \text { at }\end{array}$ & $\begin{array}{l}400 \mathrm{mg} / \mathrm{d} \text { DHA vs placebo } \\
\text { (corn and soybean oils) } \\
16 \mathrm{wk} \text { through delivery }\end{array}$ & $\begin{array}{l}\text { Executive function: Willatts } \\
\text { problem-solving task } \\
\text { at } 9 \mathrm{mo}\end{array}$ & $\begin{array}{l}\text { Non-significant: } \\
\text { All main effects } \\
\text { - Pass/fail }\end{array}$ & $\begin{array}{l}\text { - No power } \\
\text { calculation } \\
\text { - Pre-registered data } \\
\text { analysis outlined } \\
\text { multiple regression, } \\
\text { not reported in the } \\
\text { paper }\end{array}$ \\
\hline & & $\begin{array}{l}\text { BSID-III } \\
\text { at } 18 \mathrm{mo}\end{array}$ & $\begin{array}{l}\text { Non-significant: } \\
\text { All main effects (Risk that } \\
\text { placebo group fails to achieve } \\
\text { the outcome) } \\
\text { - Highest quartile cognitive score }\end{array}$ & \\
\hline $\begin{array}{l}\text { Mulder, } 2018^{23} \\
\text { Canada } \\
\mathrm{N}=89\end{array}$ & $\begin{array}{l}400 \mathrm{mg} / \mathrm{d} \text { DHA vs placebo } \\
\text { (corn and soybean oils) } \\
16 \mathrm{wk} \text { through delivery }\end{array}$ & $\begin{array}{l}\mathrm{K}-\mathrm{ABC} \\
\text { at } 5.75 \mathrm{y}\end{array}$ & $\begin{array}{l}\text { Non-significant: } \\
\text { All main effects } \\
\text { - Sequential Processing Scale } \\
\text { - Learning Ability Scale } \\
\text { - Simultaneous Processing Scale } \\
\text { - Mental Performance Index }\end{array}$ & $\begin{array}{l}\text { - Unclear whether } \\
\text { outcome assessors } \\
\text { were blinded to } \\
\text { treatment group } \\
\text { - No power } \\
\text { calculation }\end{array}$ \\
\hline
\end{tabular}




\begin{tabular}{|c|c|c|c|c|}
\hline $\begin{array}{l}\text { Study and Participant } \\
\text { Characteristics }\end{array}$ & Intervention (All RCTs) & Outcome(s) & Results & Limitations \\
\hline \multirow{3}{*}{$\begin{array}{l}\text { Mothers were age } \sim 33 y \text { at } \\
\text { enrollment and } 94.4 \% \text { completed } \\
\text { post-secondary eduation. } \\
\text { Race/Ethnicity: } \sim 74 \% \text { White. }\end{array}$} & & & & $\begin{array}{l}\text { - Pre-registered } \\
\text { analysis plan NR }\end{array}$ \\
\hline & & $\begin{array}{l}\text { Beery-Buktenica Developmental } \\
\text { Test of Visual-Motor Integration } \\
\text { at } 5.75 \mathrm{y}\end{array}$ & $\begin{array}{l}\text { Non-significant: } \\
\text { All main effects } \\
\text { - Score }\end{array}$ & \\
\hline & & $\begin{array}{l}\text { Test of Variables of Attention } \\
\text { at } 5.75 y\end{array}$ & $\begin{array}{l}\text { Non-significant: } \\
\text { All main effects } \\
\text { - RT variability } \\
\text { - RT } \\
\text { - Errors of commission } \\
\text { - Errors of omission }\end{array}$ & \\
\hline $\begin{array}{l}\text { Ostadrahimi, } 2018^{25} \\
\text { Iran } \\
\mathrm{N}=146\end{array}$ & $\begin{array}{l}120 \mathrm{mg} / \mathrm{d} \mathrm{DHA}+180 \mathrm{mg} / \mathrm{d} \\
\text { EPA vs placebo (liquid } \\
\text { paraffin) } \\
16-20 \mathrm{wk} \text { through delivery }\end{array}$ & $\begin{array}{l}\text { Parent reported: ASQ-2 } \\
\text { at } 4 \mathrm{mo} \text { and } 6 \mathrm{mo}\end{array}$ & $\begin{array}{l}\text { Non-significant: } \\
\text { All main effects } \\
\text { Total } \\
\text { - Subnormal development }\end{array}$ & $\begin{array}{l}\text { - Pre-registered } \\
\text { analysis plan NR }\end{array}$ \\
\hline $\begin{array}{l}\text { Mothers were age } \sim 26 y \text { at } \\
\text { enrollment and } \sim 8 \% \text { completed } \\
>12 \text { y education. } \sim 19 \% \text { had non- } \\
\text { adequate family income. } \\
\text { Race/ethnicity NR. }\end{array}$ & & & $\begin{array}{l}\text { Problem solving subscale } \\
\text { - Mean score } \\
\text { - Subnormal development }\end{array}$ & \\
\hline $\begin{array}{l}\text { Ramakrishnan, } 2015^{27} \\
\text { Mexico | POSGRAD } \\
\mathrm{N}=730\end{array}$ & $\begin{array}{l}400 \mathrm{mg} / \mathrm{d} \text { DHA vs placebo } \\
\text { (corn and soybean oils) } \\
18-22 \text { wk through delivery }\end{array}$ & $\begin{array}{l}\text { BSID-II: Mental Development } \\
\text { Index } \\
\text { at } 18 \mathrm{mo}\end{array}$ & $\begin{array}{l}\text { Non-significant: } \\
\text { All main effects } \\
\text { - Mean score } \\
\text { - Risk of delay }\end{array}$ & $\begin{array}{l}\text { - Pre-registered data } \\
\text { analysis NR }\end{array}$ \\
\hline \multicolumn{5}{|l|}{$\begin{array}{l}\text { Mothers were age } \sim 26 y \text { at } \\
\text { enrollment and } \sim 59 \% \text { completed } \\
\geq 12 y \text { education. }\end{array}$} \\
\hline $\begin{array}{l}\text { Ramakrishnan, 2016 } \\
\text { Mexico | POSGRAD }\end{array}$ & $\begin{array}{l}400 \mathrm{mg} / \mathrm{d} \mathrm{DHA} \text { vs placebo } \\
\text { (corn and soybean oils) }\end{array}$ & $\begin{array}{l}\text { MSCA } \\
\text { at } 5 y\end{array}$ & $\begin{array}{l}\text { Non-significant: } \\
\text { All main effects }\end{array}$ & $\begin{array}{l}\text { - Pre-registered data } \\
\text { analysis NR }\end{array}$ \\
\hline
\end{tabular}




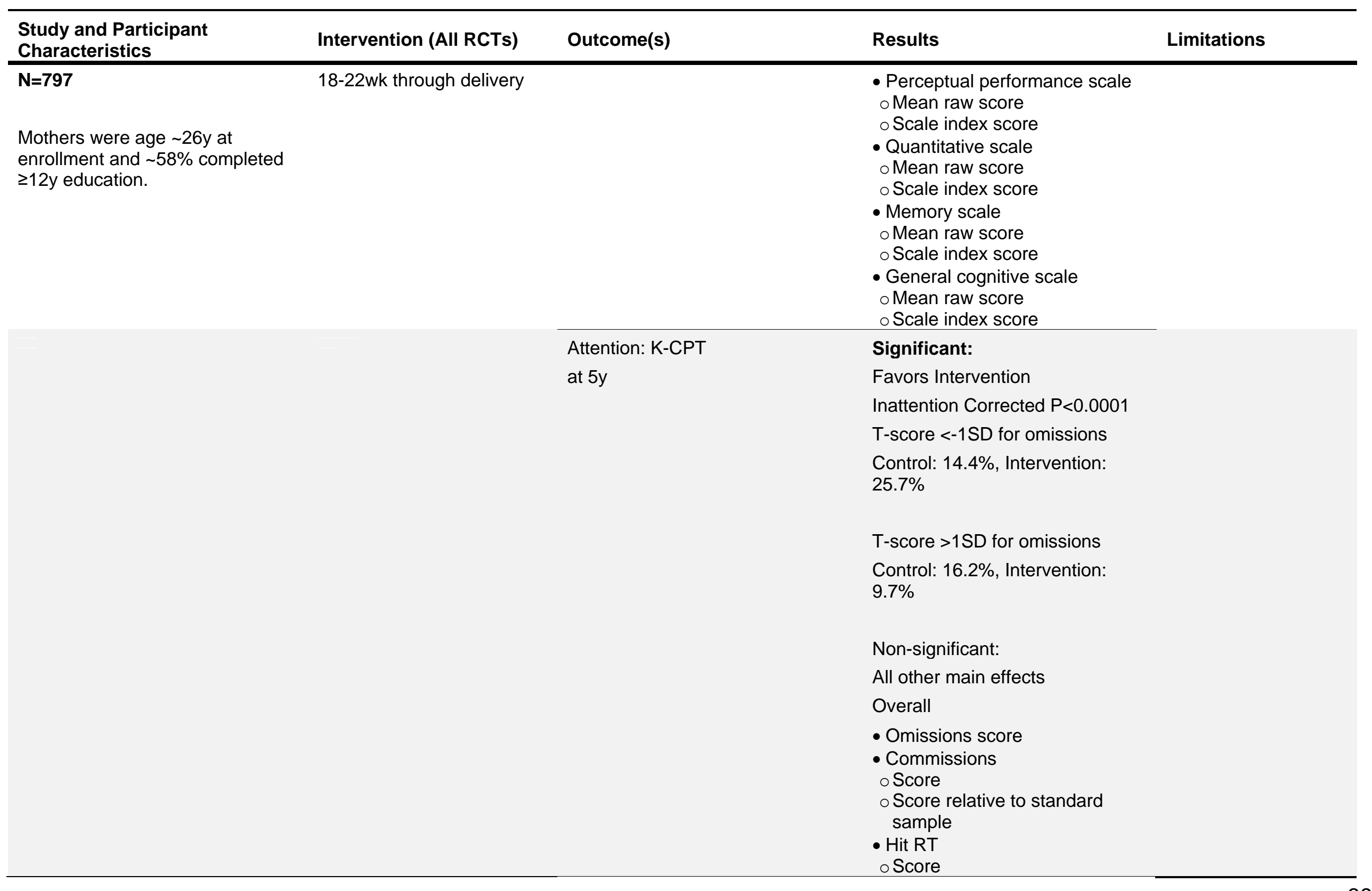




\begin{tabular}{|c|c|c|c|c|}
\hline $\begin{array}{l}\text { Study and Participant } \\
\text { Characteristics }\end{array}$ & Intervention (All RCTs) & Outcome(s) & Results & Limitations \\
\hline & & & $\begin{array}{l}\text { o Score relative to standard } \\
\text { sample } \\
\text { - Response style score relative } \\
\text { to standard sample } \\
\text { - Overall score relative to } \\
\text { standard sample } \\
\text { Inattention scores } \\
\text { - Hit RT, speed consistency } \\
\text { - Variability } \\
\text { - Detectability } \\
\text { - Hit RT ISI change } \\
\text { - Hit speed consistency ISI } \\
\text { change } \\
\text { Impulsivity scores } \\
\text { - Perseverations } \\
\text { Vigilance scores } \\
\text { - Hit RT block change } \\
\text { - Hit speed consistency by block } \\
\text { change }\end{array}$ & \\
\hline $\begin{array}{l}\text { Stein, 2012 } \\
\text { Mexico | POSGRAD } \\
\text { N=900 } \\
\text { Mothers were age } \sim 26 y \text { at } \\
\text { enrollment and } \sim 58 \% \text { completed } \\
\geq 12 y \text { education. }\end{array}$ & $\begin{array}{l}400 \mathrm{mg} / \mathrm{d} \text { DHA vs placebo } \\
\text { (corn and soybean oils) } \\
18-22 \mathrm{wk} \text { through delivery }\end{array}$ & $\begin{array}{l}\mathrm{ABR} \\
\text { at } 1 \mathrm{mo} \text { and } 3 \mathrm{mo}\end{array}$ & $\begin{array}{l}\text { Non-significant: } \\
\text { All main effects } \\
\text { - Latency } 1 \\
\text { - Latency } 3 \\
\text { - Latency } 5 \\
\text { - Interpeak latency 1-3 } \\
\text { - Interpeak latency 3-5 } \\
\text { - Interpeak latency 1-5 }\end{array}$ & $\begin{array}{l}\text { Pre-registered data } \\
\text { analysis NR }\end{array}$ \\
\hline
\end{tabular}




\begin{tabular}{|c|c|c|c|c|}
\hline $\begin{array}{l}\text { Study and Participant } \\
\text { Characteristics }\end{array}$ & Intervention (All RCTs) & Outcome(s) & Results & Limitations \\
\hline $\begin{array}{l}\text { Brei, 20171 } \\
\text { Germany | INFAT } \\
\text { N=130 } \\
\text { Mothers were age } \sim 33 y \text { at } \\
\text { enrollment and } 73 \% \text { completed } \\
\geq 12 y \text { education. Race/Ethnicity: } \\
\text { NR. }\end{array}$ & $\begin{array}{l}1020 \mathrm{mg} / \mathrm{d} \mathrm{DHA}+180 \\
\mathrm{mg} / \mathrm{d} \text { EPA }+9 \mathrm{mg} / \mathrm{d} \text { Vitamin } \\
\mathrm{E} \text { vs general nutrition } \\
\text { advice } \\
15 \text { wk gestation through } \\
4 \mathrm{mo} \text { postpartum }\end{array}$ & $\begin{array}{l}\text { Parent reported: Child } \\
\text { Development Inventory: General } \\
\text { development, Numbers } \\
\text { at } 4 y \text { and } 5 y\end{array}$ & $\begin{array}{l}\text { Non-significant: } \\
\text { All main effects } \\
\text { - General development scale } \\
\text { classification (Normal, } \\
\text { Borderline, Delay) } \\
\text { - Numbers scale classification } \\
\text { (Normal, Borderline, Delay) }\end{array}$ & $\begin{array}{l}\text { Reasons for } \\
\text { missingness by } \\
\text { group NR } \\
\text { - Results were } \\
\text { parent-reported } \\
\text { - Pre-registered data } \\
\text { analysis NR }\end{array}$ \\
\hline $\begin{array}{l}\text { Helland, } \mathbf{2 0 0 1}{ }^{13} \\
\text { Norway } \\
\text { N=245 } \\
\text { Mothers were age } \sim 28 y \text { at } \\
\text { enrollment and } \sim 72 \% \text { completed } \\
\geq 12 y \text { education. Race/ethnicity: } \\
\text { NR. }\end{array}$ & $\begin{array}{l}10 \mathrm{~mL} / \mathrm{d} \text { cod liver oil vs } \\
\text { placebo (corn oil) } \\
17-19 \text { wk gestation through } \\
\text { 3mo postpartum }\end{array}$ & $\begin{array}{l}\text { Memory: FTII } \\
\text { at } 6 \mathrm{mo} \text { and } 9 \mathrm{mo}\end{array}$ & $\begin{array}{l}\text { Non-significant: } \\
\text { All main effects } \\
\text { - Novelty preference } \\
\circ 6 \text { mo only } \\
\circ 9 \mathrm{mo} \text { only } \\
\circ 6 \mathrm{mo} \text { and } 9 \mathrm{mo} \text { combined }\end{array}$ & $\begin{array}{l}\text { - Details of allocation } \\
\text { sequence NR } \\
\text { - } 38 \% \text { withdrew } \\
\text { before delivery, } \\
\text { many due to non- } \\
\text { adherence or } \\
\text { "discomfort taking } \\
\text { the oil" } \\
\text { - Nearly } 60 \% \\
\text { attrition, unclear if } \\
\text { reasons for } \\
\text { missingness were } \\
\text { balanced across } \\
\text { groups } \\
\text { - N=130 infants } \\
\text { received cod liver } \\
\text { oil, per Norwegian } \\
\text { recs but NR by } \\
\text { groups } \\
\text { - No evidence of } \\
\text { performance above } \\
\text { chance in either } \\
\text { group } \\
\text { - Pre-registered } \\
\text { analysis NR }\end{array}$ \\
\hline $\begin{array}{l}\text { Helland, } 2003^{15} \\
\text { Norway }\end{array}$ & $\begin{array}{l}10 \mathrm{~mL} / \mathrm{d} \text { cod liver oil vs } \\
\text { placebo (corn oil) }\end{array}$ & $\begin{array}{l}\text { Intelligence: K-ABC } \\
\text { at } 4 y\end{array}$ & $\begin{array}{l}\text { Significant: } \\
\text { Favors Intervention }\end{array}$ & $\begin{array}{l}\text { - Substantial attrition, } \\
\text { unclear if reasons } \\
\text { for missingness }\end{array}$ \\
\hline
\end{tabular}




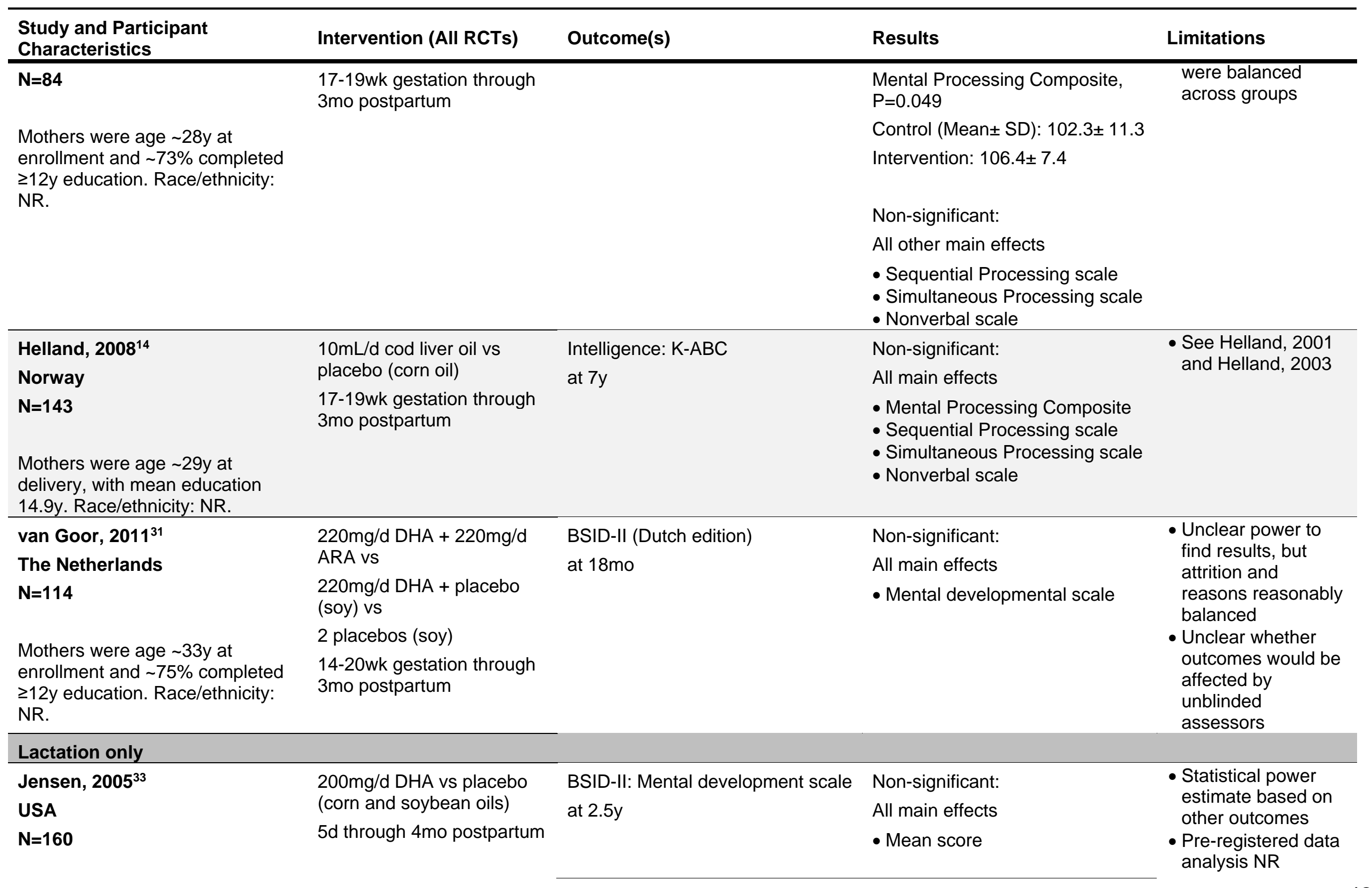




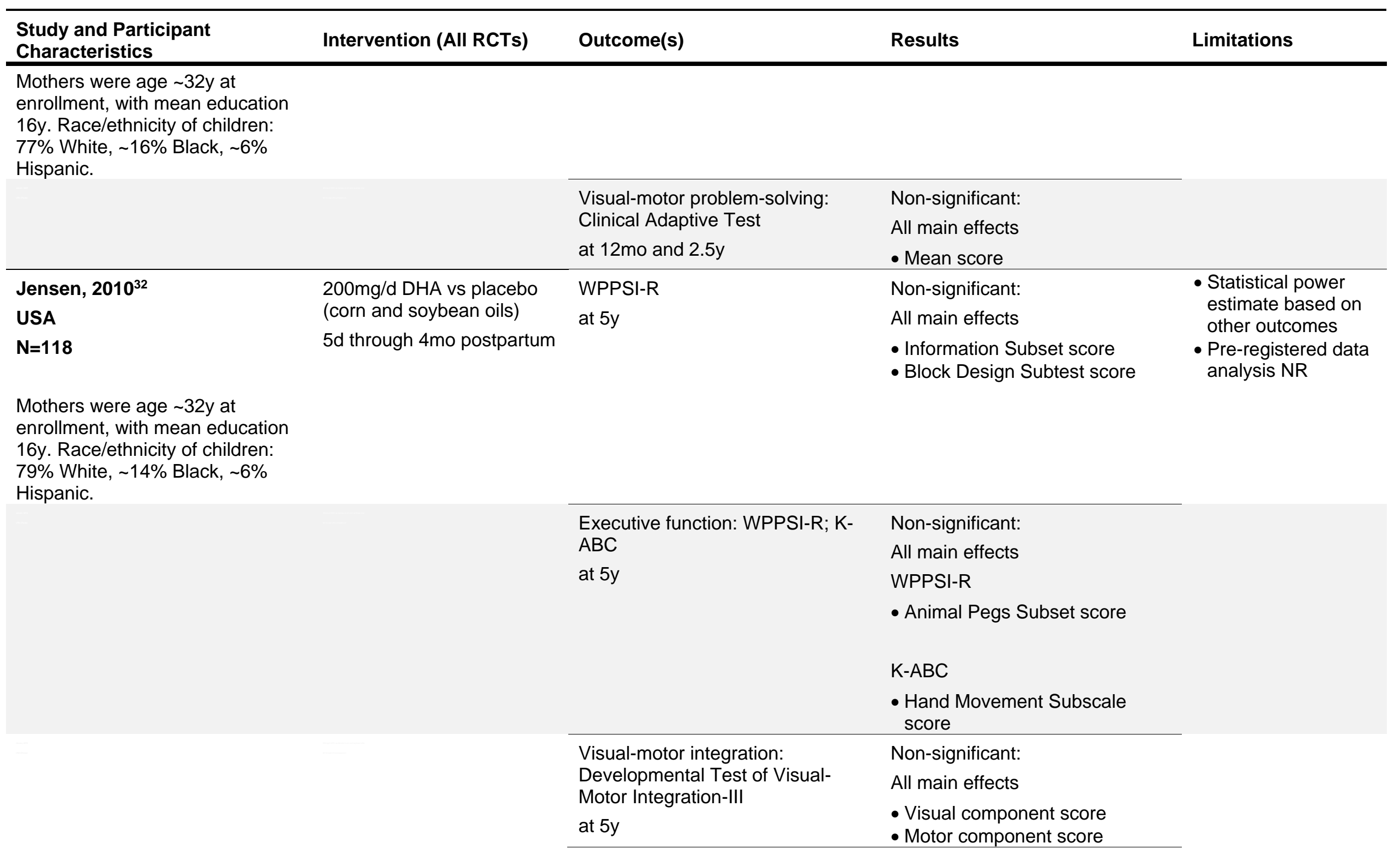


Outcome(s)

Sustained attention: Leiter International Performance Scale-

Revised:

at $5 y$
Results

Significant:

Favors intervention

Sustained attention subtest,

$\mathrm{P}=0.008$

Control (Mean \pm SD): $41.8 \pm 9.3$

Intervention: $46.5 \pm 8.9$ 


\section{Language development \\ Supplementation during pregnancy alone:}

\section{Summary:}

Seven RCTs examined the effects of omega-3 fatty acid supplementation during pregnancy alone on language development in the child (Table 3). ${ }^{6,7,10,11,18,19,22-26}$ All 7 RCTs, which assessed children from ages 3 months to 12 years, found no effect of treatment on at least one measure of language development.

Two studies found statistically significant, favorable effects of supplementation on at least one measure of language development in the child at ages 4 months, ${ }^{25}$ and ages 14 and 18 months. ${ }^{24}$ Notably, Ostadrahimi et al ${ }^{25}$ found a benefit on a continuous measure of language at 4 months, but no effect on this continuous measure at 6 months, nor on the risk of subnormal language development at either age.

Assessment of the evidencevii:

Given the mixed results and some concerns regarding risk of bias due to selection of reported results (Table 8), insufficient evidence existed to determine the relationship between omega-3 fatty acid supplementation during pregnancy alone and language development in the child, and therefore the body of evidence was rated 'grade not assignable.'

\section{Supplementation during both pregnancy and lactation:}

Summary:

One RCT examined the effects of omega- 3 fatty acid supplementation during both pregnancy and lactation on language development in the child, ${ }^{1}$ and reported a statistically significant favorable effect for a single measure of language development at age 5 years, but no association with other measures from the same tool at ages 4 years and 5 years (Table 3).

Assessment of the evidence:

The entire body of evidence consisted of a single study, with concerns regarding statistical power to detect effects in these secondary outcomes, and limited information on the generalizability of results to the general U.S. population. Therefore, insufficient evidence existed to determine the relationship between omega- 3 fatty acid supplementation during both pregnancy and lactation and language development in the child, and the body of evidence was rated 'grade not assignable.'

\section{Supplementation during lactation alone:}

\section{Summary:}

One RCT examined the effects of omega-3 fatty acid supplementation during lactation alone on language development in the child (Table 3). ${ }^{32,33}$ Jensen et $\mathrm{a}^{32,33}$ reported no

\footnotetext{
vii A detailed description of the methodology used for grading the strength of the evidence is available on the NESR website: https://nesr.usda.gov/2020-dietary-guidelines-advisory-committee-systematicreviews and in Part $\mathrm{C}$ of the following reference: Dietary Guidelines Advisory Committee. 2020. Scientific Report of the 2020 Dietary Guidelines Advisory Committee: Advisory Report to the Secretary of Agriculture and the Secretary of Health and Human Services. U.S. Department of Agriculture, Agricultural Research Service, Washington, DC.
} 
association with multiple measures of language development at ages 12 months, 2.5 years, and 5 years.

Assessment of the evidence:

The entire body of evidence consisted of a single study with concerns regarding statistical power to detect effects in these secondary outcomes, risk of bias due to outcome measurement and deviations from the intended intervention (Table 8), and a sample that may not reflect the diversity of the general U.S. population. Therefore, insufficient evidence existed to determine the relationship between omega- 3 fatty acid supplementation during lactation alone and language development in the child, and the body of evidence was rated 'grade not assignable.' 
Table 3. Description of evidence on relationship between omega-3 fatty acid supplementation and language development viii

\begin{tabular}{|c|c|c|c|c|}
\hline $\begin{array}{l}\text { Study and Participant } \\
\text { Characteristics }\end{array}$ & Intervention (All RCTs) & Outcome(s) & Results & Limitations \\
\hline \multicolumn{5}{|l|}{ Pregnancy only } \\
\hline \multirow{4}{*}{$\begin{array}{l}\text { Colombo, 2019 } \\
\text { USA | KUDOS } \\
\text { N=161 } \\
\text { Mothers were age 26y at } \\
\text { enrollment, with mean income } \\
<\$ 46 \mathrm{~K} \text { and } \sim 14 \mathrm{y} \text { education. } \\
\text { Race/Ethnicity: 6\% Hispanic, 31\% } \\
\text { Black. }\end{array}$} & $\begin{array}{l}600 \mathrm{mg} / \mathrm{d} \text { DHA vs placebo } \\
\text { (corn and soybean oils) } \\
\sim 14.5 \mathrm{wk} \text { through delivery }\end{array}$ & $\begin{array}{l}\text { MacArthur-Bates CDI } \\
\text { at } 18 \mathrm{mo}\end{array}$ & $\begin{array}{l}\text { Non-significant: } \\
\text { All main effects } \\
\text { - Words Produced } \\
\text { - Sentence Length } \\
\text { - Complexity }\end{array}$ & $\begin{array}{l}\text { - More outcomes reported in } \\
\text { the paper than on the } \\
\text { clinical trials registry } \\
\text { - Pre-registered data } \\
\text { analysis plan NR }\end{array}$ \\
\hline & & $\begin{array}{l}\text { TOPEL } \\
\text { at } 42 \mathrm{mo}\end{array}$ & $\begin{array}{l}\text { Non-significant: } \\
\text { All main effects } \\
\text { - Early Literacy Index }\end{array}$ & \\
\hline & & $\begin{array}{l}\text { Sentence Repetition tasks } \\
\text { at } 36,42,48 \mathrm{mo}\end{array}$ & $\begin{array}{l}\text { Non-significant: } \\
\text { All main effects } \\
\text { - Score }\end{array}$ & \\
\hline & & $\begin{array}{l}\text { PPVT, Third Edition } \\
\text { at } 5 y\end{array}$ & $\begin{array}{l}\text { Non-significant: } \\
\text { All main effects } \\
\text { - Standard Score }\end{array}$ & \\
\hline $\begin{array}{l}\text { Dunstan, } 2008^{7} \\
\text { Australia }\end{array}$ & $\begin{array}{l}2.2 \mathrm{~g} / \mathrm{d} \text { DHA }+1.1 \mathrm{~g} / \mathrm{d} \text { EPA vs } \\
\text { placebo (olive oil) } \\
20 w k \text { through delivery }\end{array}$ & $\begin{array}{l}\text { Language Development Survey; } \\
\text { Receptive: PPVT-IIIA }\end{array}$ & $\begin{array}{l}\text { Non-significant: } \\
\text { All main effects }\end{array}$ & $\begin{array}{l}\text { - Probable differences in } \\
\text { reasons for attrition }\end{array}$ \\
\hline
\end{tabular}

viii Adj: adjusted; ASQ: Ages and Stages Questionnaire; BSID: Bayley Scales of Infant Development; CDI: Communicative Development Inventory; CELF(P2): Clinical Evaluation of Language Fundamentals (Preschool, second edition); CI: confidence interval; CLAMS: Clinical Linguistic and Auditory Milestone Scale; DHA: docosahexaenoic acid; DOMInO: DHA to Optimize Mother Infant Outcome; EPA: eicosapentaenoic acid; ETA: eicosatetranoic acid; INFAT:

The Impact of the Nutritional Fatty Acids During Pregnancy and Lactation for Early Human Adipose Tissue Development; KUDOS: Kansas University DHA Outcomes Study; MSCA: McCarthy Scales of Children's Abilities; NR: not reported; PPVT: Peabody Picture Vocabulary Test; RCT: randomized controlled trial; TOPEL: Test of Preschool Early Literacy; WPPSI-R: Wechsler Primary and Preschool Scale of Intelligence-Revised 


\begin{tabular}{|c|c|c|c|c|}
\hline $\begin{array}{l}\text { Study and Participant } \\
\text { Characteristics }\end{array}$ & Intervention (All RCTs) & Outcome(s) & Results & Limitations \\
\hline $\begin{array}{l}\mathbf{N}=\mathbf{7 2} \\
\text { Mothers were age } \sim 32 y \text { at } \\
\text { enrollment and } \sim 73 \% \text { completed } \\
\geq 12 y \text { education. Race/Ethnicity: } \\
100 \% \text { White. }\end{array}$ & & at $2.5 y$ & - Standard Score & $\begin{array}{l}\text { - No power calculation for } \\
\text { neurobehavioral results } \\
\text { - Pre-registered data } \\
\text { analysis plan NR }\end{array}$ \\
\hline $\begin{array}{l}\text { Gould, 2017 } \\
\text { Australia | DOMInO } \\
\text { N=543 } \\
\text { Mothers were age } \sim 30 y \text { at } \\
\text { enrollment and } \sim 66 \% \text { completed } \\
\text { secondary education. } \\
\text { Race/ethnicity NR. }\end{array}$ & $\begin{array}{l}800 \mathrm{mg} / \mathrm{d} \text { DHA }+100 \mathrm{mg} / \mathrm{d} \\
\text { EPA vs Vegetable oil } \\
\text { (rapeseed, } \\
\text { sunflower, and palm) placebo } \\
18-21 \text { wk through delivery }\end{array}$ & $\begin{array}{l}\text { CELF-4: Core language score } \\
\text { at } 7 y\end{array}$ & $\begin{array}{l}\text { Non-significant: } \\
\text { All main effects } \\
\text { - Score }\end{array}$ & - No major limitations \\
\hline $\begin{array}{l}\text { Keenan, 2016 } \\
\text { USA } \\
\mathrm{N}=49 \\
\text { Age } 20-30 y .100 \% \text { Medicaid } \\
\text { eligible. Race/Ethnicity: } 100 \% \\
\text { Black. }\end{array}$ & $\begin{array}{l}450 \mathrm{mg} / \mathrm{d} \mathrm{DHA}+40 \mathrm{mg} / \mathrm{d} \\
\mathrm{DPA}+40 \mathrm{mg} / \mathrm{d} \text { ETA }+90 \\
\mathrm{mg} / \mathrm{d} \text { EPA }+10 \mathrm{mg} / \mathrm{d} \text { Vitamin } \\
\mathrm{E} \mathrm{vs} 990 \mathrm{mg} / \mathrm{d} \text { soybean oil }+ \\
16.5 \mathrm{mg} / \mathrm{d} \text { Vitamin } \mathrm{E}+10 \\
\mathrm{mg} / \mathrm{d} \mathrm{EPA}+10 \mathrm{mg} / \mathrm{d} \text { DHA } \\
16-21 \mathrm{wk} \text { for } 6 \mathrm{wk}\end{array}$ & $\begin{array}{l}\text { BSID-III: Receptive and } \\
\text { Expressive Communication } \\
\text { at } 3 \mathrm{mo}\end{array}$ & $\begin{array}{l}\text { Non-significant: } \\
\text { All main effects } \\
\text { - Receptive } \\
\text { Communication } \\
\text { - Expressive } \\
\text { Communication }\end{array}$ & $\begin{array}{l}\text { - Reasons for missingness } \\
\text { by group NR } \\
\text { - Pre-registered data } \\
\text { analysis plan NR }\end{array}$ \\
\hline $\begin{array}{l}\text { Makrides, } 2010^{19} \\
\text { Australia | DOMInO } \\
\mathrm{N}=694 \\
\text { Mothers were age } \sim 29 y \text { at } \\
\text { enrollment and } \sim 68 \% \text { completed } \\
\text { more than secondary education. } \\
\text { Race/ethnicity NR. }\end{array}$ & $\begin{array}{l}800 \mathrm{mg} / \mathrm{d} \mathrm{DHA}+100 \mathrm{mg} / \mathrm{d} \\
\text { EPA vs Vegetable oil } \\
\text { (rapeseed, } \\
\text { sunflower, and palm) placebo } \\
18-21 \text { wk through delivery }\end{array}$ & $\begin{array}{l}\text { BSID-III: Language Scale, } \\
\text { continuous, delayed, and } \\
\text { accelerated } \\
\text { at } 18 \mathrm{mo}\end{array}$ & $\begin{array}{l}\text { Non-significant: } \\
\text { All main effects } \\
\text { - Language Standardized } \\
\text { Score, Continuous } \\
\text { - Language Standardized } \\
\text { Score, Delayed } \\
\text { - Language Standardized } \\
\text { Score, Accelerated }\end{array}$ & $\begin{array}{l}\text { - Pre-registered analysis } \\
\text { plan NR }\end{array}$ \\
\hline
\end{tabular}




\begin{tabular}{|c|c|c|c|c|}
\hline $\begin{array}{l}\text { Study and Participant } \\
\text { Characteristics }\end{array}$ & Intervention (All RCTs) & Outcome(s) & Results & Limitations \\
\hline $\begin{array}{l}\text { Makrides, } 2014^{20} \\
\text { Autralia | DOMInO } \\
\mathrm{N}=646 \\
\text { Mothers were age } \sim 29 \mathrm{y} \text { at } \\
\text { enrollment and } \sim 68 \% \text { completed } \\
\text { more than secondary education. } \\
\text { Race/ethnicity NR. }\end{array}$ & $\begin{array}{l}800 \mathrm{mg} / \mathrm{d} \mathrm{DHA}+100 \mathrm{mg} / \mathrm{d} \\
\text { EPA vs Vegetable oil } \\
\text { (rapeseed, } \\
\text { sunflower, and palm) placebo } \\
18-21 \mathrm{wk} \text { through delivery }\end{array}$ & $\begin{array}{l}\text { CELF-P2 } \\
\text { at } 4 y\end{array}$ & $\begin{array}{l}\text { Non-significant: } \\
\text { All main effects } \\
\text { - Core language score }\end{array}$ & $\begin{array}{l}\text { - Pre-registered analysis } \\
\text { plan NR }\end{array}$ \\
\hline $\begin{array}{l}\text { Meldrum, } 2015 \\
\text { Australia } \\
\mathrm{N}=\mathbf{4 8} \\
\text { Mothers were age } \sim 32 \mathrm{y} \text { at } \\
\text { enrollment and } \sim 73 \% \text { completed } \\
\geq 12 \mathrm{y} \text { education. Race/Ethnicity: } \\
100 \% \text { White. }\end{array}$ & $\begin{array}{l}2.2 \mathrm{~g} / \mathrm{d} \mathrm{DHA}+1.1 \mathrm{~g} / \mathrm{d} \text { EPA vs } \\
\text { placebo (olive oil) } \\
20 \mathrm{wk} \text { through delivery }\end{array}$ & $\begin{array}{l}\text { Child Communication Checklist } \\
\text { at } 12 y\end{array}$ & $\begin{array}{l}\text { Non-significant: } \\
\text { All main effects } \\
\text { - Percentile rank }\end{array}$ & $\begin{array}{l}\text { - Among those followed to } \\
12 y, \text { birth weight differed } \\
\text { by treatment group } \\
\text { - Possible differences in } \\
\text { reasons for attrition } \\
\text { - No power calculation, } \\
\text { Likely under-powered }\end{array}$ \\
\hline $\begin{array}{l}\text { Mulder, } 2013^{24} \\
\text { Canada } \\
\mathrm{N}=154\end{array}$ & $\begin{array}{l}400 \mathrm{mg} / \mathrm{d} \text { DHA vs placebo } \\
\text { (corn and soybean oils) } \\
16 \mathrm{wk} \text { through delivery }\end{array}$ & $\begin{array}{l}\text { Non-native consonant } \\
\text { recognition task } \\
\text { at } 9 \mathrm{mo}\end{array}$ & $\begin{array}{l}\text { Non-significant: } \\
\text { All main effects } \\
\text { - Pass/Fail }\end{array}$ & $\begin{array}{l}\text { - No power calculation } \\
\text { - Pre-registered data } \\
\text { analysis outlined multiple } \\
\text { regression, NR in paper }\end{array}$ \\
\hline \multicolumn{5}{|l|}{$\begin{array}{l}\text { Mothers were age } \sim 33 y \text { at } \\
\text { enrollment and } 94.4 \% \text { completed } \\
\text { post-secondary eduation. } \\
\text { Race/Ethnicity: } \sim 74 \% \text { White. }\end{array}$} \\
\hline & & $\begin{array}{l}\text { MacArthur Infant CDI } \\
\text { at } 14 \mathrm{mo}\end{array}$ & $\begin{array}{l}\text { Significant: } \\
\text { Favors intervention } \\
\text { All main effects (Risk that } \\
\text { placebo group fails to } \\
\text { achieve the outcome) }\end{array}$ & \\
\hline & & & $\begin{array}{l}\text { Highest quartile words } \\
\text { understood }\end{array}$ & \\
\hline
\end{tabular}




\begin{tabular}{|c|c|c|c|c|}
\hline \multirow[t]{6}{*}{$\begin{array}{l}\text { Study and Participant } \\
\text { Characteristics }\end{array}$} & Intervention (All RCTs) & Outcome(s) & Results & Limitations \\
\hline & & & Adj $P=0.002$ & \\
\hline & & & $\begin{array}{l}\text { Adj OR: } 3.22,95 \% \mathrm{Cl}: \\
(1.49-6.94)\end{array}$ & \\
\hline & & & $\begin{array}{l}\text { Highest quartile words } \\
\text { produced }\end{array}$ & \\
\hline & & & Adj $P=0.009$ & \\
\hline & & & $\begin{array}{l}\text { Adj OR: } 2.61,95 \% \mathrm{Cl}: \\
(1.22-5.58)\end{array}$ & \\
\hline & & \multirow{11}{*}{$\begin{array}{l}\text { MacArthur Infant and Toddler } \\
\text { CDI } \\
\text { at } 18 \mathrm{mo}\end{array}$} & Significant: & \\
\hline & & & Favors intervention & \\
\hline & & & $\begin{array}{l}\text { All other main effects (Risk } \\
\text { that placebo group fails to } \\
\text { achieve the outcome) }\end{array}$ & \\
\hline & & & $\begin{array}{l}\text { Infant Highest quartile } \\
\text { words understood }\end{array}$ & \\
\hline & & & Adj $P=0.01$ & \\
\hline & & & $\begin{array}{l}\text { Adj OR: } 2.77,95 \% \mathrm{Cl} \text { : } \\
(1.23-6.28)\end{array}$ & \\
\hline & & & $\begin{array}{l}\text { Toddler Highest quartile } \\
\text { words produced }\end{array}$ & \\
\hline & & & Adj $P=0.02$ & \\
\hline & & & $\begin{array}{l}\text { Adj OR: } 2.60,95 \% \mathrm{Cl} \text { : } \\
(1.15-5.89)\end{array}$ & \\
\hline & & & Non-significant: & \\
\hline & & & $\begin{array}{l}\text { Infant Highest quartile } \\
\text { words produced }\end{array}$ & \\
\hline & & $\begin{array}{l}\text { BSID-III: Language composite } \\
\text { scale }\end{array}$ & $\begin{array}{l}\text { Significant: } \\
\text { Favors intervention }\end{array}$ & \\
\hline
\end{tabular}




\begin{tabular}{|c|c|c|c|c|}
\hline $\begin{array}{l}\text { Study and Participant } \\
\text { Characteristics }\end{array}$ & Intervention (All RCTs) & Outcome(s) & Results & Limitations \\
\hline & & at $18 \mathrm{mo}$ & $\begin{array}{l}\text { (Risk that placebo group } \\
\text { fails to achieve the } \\
\text { outcome) } \\
\text { Receptive language } \\
\text { Adj } P=0.03 \\
\text { Adj OR: } 2.23,95 \% \mathrm{Cl} \text { : } \\
(1.08,4.60) \\
\text { Non-significant: } \\
\text { Expressive language }\end{array}$ & \\
\hline $\begin{array}{l}\text { Mulder, } 2018^{23} \\
\text { Canada } \\
\mathrm{N}=89 \\
\text { Mothers were age } \sim 33 y \text { at } \\
\text { enrollment and } 94.4 \% \text { completed } \\
\text { post-secondary eduation. } \\
\text { Race/Ethnicity: } \sim 74 \% \text { White. }\end{array}$ & $\begin{array}{l}400 \mathrm{mg} / \mathrm{d} \text { DHA vs placebo } \\
\text { (corn and soybean oils) } \\
16 \mathrm{wk} \text { through delivery }\end{array}$ & $\begin{array}{l}\text { Receptive: PPVT-4 } \\
\text { at } 5.75 y\end{array}$ & $\begin{array}{l}\text { Non-significant: } \\
\text { All main effects } \\
\text { - Score }\end{array}$ & $\begin{array}{l}\text { - Unclear whether outcome } \\
\text { assessors were blinded to } \\
\text { treatment group } \\
\text { - No power calculation } \\
\text { - Pre-registered analysis } \\
\text { plan NR }\end{array}$ \\
\hline $\begin{array}{l}\text { Ostadrahimi, } 2018^{25} \\
\text { Iran } \\
\mathrm{N}=146\end{array}$ & $\begin{array}{l}120 \mathrm{mg} / \mathrm{d} \mathrm{DHA}+180 \mathrm{mg} / \mathrm{d} \\
\text { EPA vs placebo (liquid } \\
\text { paraffin) } \\
16-20 \mathrm{wk} \text { through delivery }\end{array}$ & $\begin{array}{l}\text { Parent reported: ASQ-2 } \\
\text { Communciation subscale } \\
\text { at } 4 \mathrm{mo}\end{array}$ & $\begin{array}{l}\text { Significant: } \\
\text { Favors intervention } \\
4 \mathrm{mo}, \text { mean score } \\
\text { Adj } P=0.02\end{array}$ & $\begin{array}{l}\text { - Pre-registered analysis } \\
\text { plan NR }\end{array}$ \\
\hline \multirow{2}{*}{$\begin{array}{l}\text { Mothers were age } \sim 26 y \text { at } \\
\text { enrollment and } \sim 8 \% \text { completed } \\
>12 \text { y education. } \sim 19 \% \text { had non- } \\
\text { adequate family income. } \\
\text { Race/ethnicity NR. }\end{array}$} & & & $\begin{array}{l}\text { Ref: Control } \\
\text { Adj Mean Difference: } \\
2.63,95 \% \mathrm{Cl}:(0.36,4.89)\end{array}$ & \\
\hline & & & $\begin{array}{l}\text { Non-significant: } \\
\text { All other main effects } \\
\text { - Mean score } \\
\text { - Subnormal development }\end{array}$ & \\
\hline
\end{tabular}




\begin{tabular}{|c|c|c|c|c|}
\hline $\begin{array}{l}\text { Study and Participant } \\
\text { Characteristics }\end{array}$ & Intervention (All RCTs) & Outcome(s) & Results & Limitations \\
\hline & & $\begin{array}{l}\text { Communciation subscale } \\
\text { at } 6 \mathrm{mo}\end{array}$ & $\begin{array}{l}\text { Non-significant: } \\
\text { All other main effects } \\
\text { - Mean score } \\
\text { - Subnormal development }\end{array}$ & \\
\hline $\begin{array}{l}\text { Ramakrishnan, } 2016^{26} \\
\text { Mexico } \\
\mathrm{N}=797\end{array}$ & $\begin{array}{l}400 \mathrm{mg} / \mathrm{d} \text { DHA vs placebo } \\
\text { (corn and soybean oils) } \\
18-22 \text { wk through delivery }\end{array}$ & $\begin{array}{l}\text { MSCA: Verbal scale } \\
\text { at } 5 y\end{array}$ & $\begin{array}{l}\text { Non-significant: } \\
\text { All main effects } \\
\text { - Mean raw score } \\
\text { - Mean scale index score }\end{array}$ & $\begin{array}{l}\text { - Pre-registered data } \\
\text { analysis NR }\end{array}$ \\
\hline $\begin{array}{l}\text { Mothers were age } \sim 26 y \text { at } \\
\text { enrollment and } \sim 58 \% \text { completed } \\
\geq 12 \text { y education. }\end{array}$ & & & & \\
\hline Pregnancy and Lactation & & & & \\
\hline $\begin{array}{l}\text { Brei, } 2017^{1} \\
\text { Germany | INFAT } \\
\text { N=130 } \\
\text { Mothers were age } \sim 33 y \text { at } \\
\text { enrollment and } 73 \% \text { completed } \\
\geq 12 y \text { education. Race/Ethnicity: NR. }\end{array}$ & $\begin{array}{l}1020 \mathrm{mg} / \mathrm{d} \mathrm{DHA}+180 \mathrm{mg} / \mathrm{d} \\
\text { EPA }+9 \mathrm{mg} / \mathrm{d} \text { Vitamin } \mathrm{E} \text { vs } \\
\text { general nutrition advice } \\
15 \text { wk gestation through } 4 \mathrm{mo} \\
\text { postpartum }\end{array}$ & $\begin{array}{l}\text { Parent reported: Child } \\
\text { Development Inventory: } \\
\text { Expressive, language } \\
\text { comprehension, letters scales } \\
\text { at } 4 \mathrm{y} \text { and } 5 \mathrm{y}\end{array}$ & $\begin{array}{l}\text { Significant: } \\
\text { Favors intervention } \\
\text { Letter scales at } 5 y \\
\text { Borderline/developmentally } \\
\text { delayed, } \mathrm{P}=0.043 \\
\text { Control: } \mathrm{N}=4 \text { of } 60 \\
\text { Intervention: } \mathrm{N}=0 \text { of } 70 \\
\text { Non-significant: } \\
\text { All other main effects } \\
\text { - Expressive language } \\
\text { scale classification } \\
\text { (Normal, Borderline, } \\
\text { Delay) } \\
\text { - Language } \\
\text { comprehension scale } \\
\text { classification (Normal, } \\
\text { Borderline, Delay) }\end{array}$ & $\begin{array}{l}\text { - Reasons for missingness } \\
\text { by group NR } \\
\text { - Results were parent- } \\
\text { reported } \\
\text { - Pre-registered data } \\
\text { analysis NR }\end{array}$ \\
\hline
\end{tabular}




\begin{tabular}{|c|c|c|c|c|}
\hline $\begin{array}{l}\text { Study and Participant } \\
\text { Characteristics }\end{array}$ & Intervention (All RCTs) & Outcome(s) & Results & Limitations \\
\hline $\begin{array}{l}\text { Jensen, } 2005^{33} \\
\text { USA } \\
N=160\end{array}$ & $\begin{array}{l}200 \mathrm{mg} / \mathrm{d} \text { DHA vs placebo } \\
\text { (corn and soybean oils) } \\
5 \mathrm{~d} \text { through } 4 \text { mo postpartum }\end{array}$ & $\begin{array}{l}\text { CLAMS } \\
\text { at } 12 \mathrm{mo} \text { and } 2.5 \mathrm{y}\end{array}$ & $\begin{array}{l}\text { Non-significant: } \\
\text { All main effects } \\
\text { - Mean score }\end{array}$ & $\begin{array}{l}\text { - Statistical power estimate } \\
\text { based on other outcomes } \\
\text { - Pre-registered data } \\
\text { analysis NR }\end{array}$ \\
\hline $\begin{array}{l}\text { Mothers were age } \sim 32 y \text { at } \\
\text { enrollment, with mean education } \\
16 y . \text { Race/ethnicity of children: } 77 \% \\
\text { White, } \sim 16 \% \text { Black, } \sim 6 \% \text { Hispanic. }\end{array}$ & & & & \\
\hline $\begin{array}{l}\text { Jensen, } 2010^{32} \\
\text { USA } \\
\mathrm{N}=118\end{array}$ & $\begin{array}{l}200 \mathrm{mg} / \mathrm{d} \text { DHA vs placebo } \\
\text { (corn and soybean oils) } \\
5 \mathrm{~d} \text { through } 4 \text { mo postpartum }\end{array}$ & $\begin{array}{l}\text { WPPSI-R } \\
\text { at } 5 y\end{array}$ & $\begin{array}{l}\text { Non-significant: } \\
\text { All main effects } \\
\text { - Vocabulary Subtest } \\
\text { score }\end{array}$ & $\begin{array}{l}\text { - Statistical power estimate } \\
\text { based on other outcomes } \\
\text { - Pre-registered data } \\
\text { analysis NR }\end{array}$ \\
\hline $\begin{array}{l}\text { Mothers were age } \sim 32 y \text { at } \\
\text { enrollment, with mean education } \\
16 y . \text { Race/ethnicity of children: } 79 \% \\
\text { White, } \sim 14 \% \text { Black, } \sim 6 \% \text { Hispanic. }\end{array}$ & & & & \\
\hline
\end{tabular}




\section{Motor development \\ Supplementation during pregnancy alone:}

\section{Summary:}

Seven RCTs examined the effects of omega-3 fatty acid supplementation during

pregnancy alone on motor development in the child (ages 1 week to 5.5 years) $2,12,18,19,24-27$

(Table 4). Of those 7 RCTs, 6 found no treatment effect on at least one measure of motor development among children ages 1 week to 5.5 years. ${ }^{2,18,19,24-27}$ Gustafson et al ${ }^{12}$ found statistically significant, favorable effects of supplementation on a single measure of motor function in the neonate.

Assessment of the evidenceix:

Given the mixed results and concerns regarding risk of bias due to missing outcome data, outcome measurement, and selection of reported results, insufficient evidence existed to determine the relationship between omega-3 fatty acid supplementation during pregnancy alone and motor development in the child, and therefore the body of evidence was rated 'grade not assignable.'

\section{Supplementation during both pregnancy and lactation:}

Summary:

Both of the RCTs that examined the effect of omega-3 fatty acid supplementation during both pregnancy and lactation found no statistically significant effect on at least one measure of motor development in the child (ages 2 weeks to 5 years) ${ }^{1,30,31}$ (Table 4). Brei et $\mathrm{al}^{1}$ found that a single measure of motor development, namely, the mirror movement ratio in the dominant hand only at 5 years, was more favorable in the intervention group than in the control group, but no other measures were statistically significantly different. At 2 weeks and 12 weeks postpartum, van Goor et al ${ }^{30}$ found that infants whose mothers consumed DHA had a greater risk of mildly abnormal general movements compared to infants whose mothers consumed placebo. There were no differences in quality of general movements among infants whose mothers consumed DHA+ARA versus placebo or whose mothers consumed DHA+ARA versus DHA. Notably, the rates of mildly abnormal movements exceeded rates in other studies of healthy infants, and thus the authors disclosed blinding and discontinued the intervention before reaching recruitment goals.

Assessment of the evidence:

Given the mixed results, the early discontinuation of one of the trials (due to adverse effects of DHA supplements), concerns regarding risk of bias due to outcome measurement and selection of reported results, and limited information on the generalizability of results to the general U.S. population, insufficient evidence existed to determine the relationship between omega-3 fatty acid supplementation during both pregnancy and lactation and motor development in the child, and therefore the body of evidence was rated 'grade not assignable.'

\footnotetext{
${ }^{\text {ix }}$ A detailed description of the methodology used for grading the strength of the evidence is available on the NESR website: https://nesr.usda.gov/2020-dietary-guidelines-advisory-committee-systematicreviews and in Part $\mathrm{C}$ of the following reference: Dietary Guidelines Advisory Committee. 2020. Scientific Report of the 2020 Dietary Guidelines Advisory Committee: Advisory Report to the Secretary of Agriculture and the Secretary of Health and Human Services. U.S. Department of Agriculture, Agricultural Research Service, Washington, DC.
} 


\section{Supplementation during lactation alone:}

Summary:

A single RCT examined the effect of omega-3 fatty acid supplementation during lactation alone on motor development in the child (ages 12 months to 5 years) ${ }^{32,33}$ (Table 4). Jensen et al ${ }^{32,33}$ reported higher scores on one measure of motor development at age 2.5 years, ${ }^{33}$ and the authors noted that scores in both the supplemented and placebo groups were higher than in other studies of healthy toddlers. Additional results revealed no association with other measures of motor development at ages 12 months, 2.5 years, and 5 years.

Assessment of the evidence:

The entire body of evidence consisted of a single study with concerns regarding statistical power to detect effects in these secondary outcomes, risk of bias due to outcome measurement and deviations from the intended intervention (Table 8), and a sample that may not reflect the diversity of the general U.S. population. Therefore, insufficient evidence existed to determine the relationship between omega-3 fatty acid supplementation during lactation alone and motor development in the child, and the body of evidence was rated 'grade not assignable.' 
Table 4. Description of evidence on relationship between omega-3 fatty acid supplementation and motor development

\begin{tabular}{|c|c|c|c|c|}
\hline $\begin{array}{l}\text { Study and Participant } \\
\text { Characteristics }\end{array}$ & Intervention (All RCTs) & Outcome(s) & Results & Limitations \\
\hline \multicolumn{5}{|l|}{ Pregnancy Only } \\
\hline \multirow{4}{*}{$\begin{array}{l}\text { Escolano-Margarit, } 2011^{8} \\
\text { Germany, Hungary, Spain | } \\
\text { NUHEAL } \\
\text { N=167 }\end{array}$} & Placebo vs & \multirow{5}{*}{$\begin{array}{l}\text { Hempel Assessment } \\
\text { at } 4 \mathrm{y}\end{array}$} & \multirow{5}{*}{$\begin{array}{l}\text { Non-significant: } \\
\text { All main effects } \\
\text { - Clinical conclusion } \\
\text { (normal, simple MND, } \\
\text { complex MND) } \\
\text { - NOS } \\
\text { - Fluency score }\end{array}$} & \multirow{8}{*}{$\begin{array}{l}\text { - Outcome assessor } \\
\text { binding NR, but } \\
\text { standard methods } \\
\text { used } \\
\text { - Pre-registered analysis } \\
\text { plan NR }\end{array}$} \\
\hline & FO: $500 \mathrm{mg} / \mathrm{d} D H A+150$ & & & \\
\hline & 5-MTHF: 400 ug/d vs & & & \\
\hline & $\mathrm{FO}+5-\mathrm{MTHF}$ & & & \\
\hline \multirow{4}{*}{$\begin{array}{l}\text { Mothers were age } \sim 31 \text { y at } \\
\text { enrollment and } \sim 48 \% \text { eligible for } \\
\text { university entrance or degree. } \\
\text { Race/ethnicity NR. }\end{array}$} & 20wk through delivery & & & \\
\hline & & Touwen Assessment at 5.5y & Non-significant: & \\
\hline & & & All main effects & \\
\hline & & & $\begin{array}{l}\text { - Clinical conclusion } \\
\text { (normal, simple MND, } \\
\text { complex MND) } \\
\text { - NOS }\end{array}$ & \\
\hline \multirow{4}{*}{$\begin{array}{l}\text { Gustafson, } 2013^{12} \\
\text { USA } \\
\mathrm{N}=44\end{array}$} & 600 mg/d DHA vs & NBAS Motor scale & \multirow{4}{*}{$\begin{array}{l}\text { Significant: } \\
\text { Favors intervention } \\
\text { Adj } P=0.038 \\
\text { Control (Mean } \pm S D): \\
23.08 \pm 11.40\end{array}$} & \multirow{5}{*}{$\begin{array}{l}\text { - No power calculation } \\
\text { - Pre-registered analysis } \\
\text { plan NR }\end{array}$} \\
\hline & $\begin{array}{l}\text { placebo (corn and } \\
\text { soybean oils) }\end{array}$ & at $1 w k$ & & \\
\hline & 12-20wk through delivery & & & \\
\hline & & & & \\
\hline $\begin{array}{l}\text { Mothers were age } \sim 26 y \text { at } \\
\text { enrollment and completed } \sim 14 y \\
\text { education. Race/Ethnicity: }\end{array}$ & & & $\begin{array}{l}\text { Intervention: } 26.07 \pm \\
18.13\end{array}$ & \\
\hline
\end{tabular}

× Adj: adjusted; ARA: arachidonic acid; ASQ: Ages and Stages Questionnaire; BSID: Bayley Scales of Infant Development; Cl: confidence interval; DHA: docosahexaenoic acid; DOMInO: DHA to Optimize Mother Infant Outcome; EPA: eicosapentaenoic acid; ETA: eicosatetranoic acid; FO: fish oil; K-ABC: Kaufman Assessment Battery for Children; MSCA: McCarthy Scales of Children's Abilities; MND: minor neurological dysfunction; MTHF: methyl tetrahydrofolate; NOS: neurological optimality score; NR: not reported; NUHEAL: Nutraceuticals for a Healthier Life; POSGRAD: Prenatal Omega 3 Supplementation on child Growth and Development; RCT: randomized controlled trial 


\begin{tabular}{|c|c|c|c|c|}
\hline $\begin{array}{l}\text { Study and Participant } \\
\text { Characteristics }\end{array}$ & Intervention (All RCTs) & Outcome(s) & Results & Limitations \\
\hline \multicolumn{5}{|l|}{$\begin{array}{l}\text { 37.3\% Black, 46.3\% White, } \\
\text { 13.4\% Hispanic, 3\% Asian. }\end{array}$} \\
\hline $\begin{array}{l}\text { Keenan, } 2016^{18} \\
\text { USA } \\
\text { N=49 } \\
\text { Age 20-30y. 100\% Medicaid } \\
\text { eligible. Race/Ethnicity: 100\% } \\
\text { Black. }\end{array}$ & $\begin{array}{l}450 \mathrm{mg} / \mathrm{d} \text { DHA }+40 \mathrm{mg} / \mathrm{d} \\
\mathrm{DPA}+40 \mathrm{mg} / \mathrm{d} \text { ETA }+90 \\
\mathrm{mg} / \mathrm{d} \text { EPA }+10 \mathrm{mg} / \mathrm{d} \\
\text { Vitamin E } \\
990 \mathrm{mg} / \mathrm{d} \text { soybean oil }+ \\
16.5 \mathrm{mg} / \mathrm{d} \text { Vitamin } \mathrm{E}+10 \\
\mathrm{mg} / \mathrm{d} \mathrm{EPA}+10 \mathrm{mg} / \mathrm{d} \\
\mathrm{DHA} \\
16-21 \mathrm{wk} \text { for } 6 \mathrm{wk}\end{array}$ & $\begin{array}{l}\text { BSID-III: Fine motor and gross motor } \\
\text { scales } \\
\text { at } 3 \mathrm{mo}\end{array}$ & $\begin{array}{l}\text { Non-significant: } \\
\text { All main effects } \\
\text { - Fine motor scale } \\
\text { - Gross motor scale }\end{array}$ & $\begin{array}{l}\text { - Reasons for } \\
\text { missingness by group } \\
\text { NR } \\
\text { - Pre-registered data } \\
\text { analysis plan NR }\end{array}$ \\
\hline $\begin{array}{l}\text { Makrides, } 2010^{19} \\
\text { Australia | DOMInO } \\
\mathrm{N}=694\end{array}$ & $\begin{array}{l}800 \mathrm{mg} / \mathrm{d} \text { DHA }+100 \\
\mathrm{mg} / \mathrm{d} \text { EPA vs Vegetable } \\
\text { oil placebo } \\
18-21 \text { wk through delivery }\end{array}$ & $\begin{array}{l}\text { BSID-III: Motor scubscale } \\
\text { at } 18 \mathrm{mo}\end{array}$ & $\begin{array}{l}\text { Non-significant: } \\
\text { All main effects } \\
\text { Motor Standardized } \\
\text { Score }\end{array}$ & $\begin{array}{l}\text { - Pre-registered analysis } \\
\text { plan NR }\end{array}$ \\
\hline $\begin{array}{l}\text { Mothers were age } \sim 29 y \text { at } \\
\text { enrollment and } \sim 68 \% \text { completed } \\
\text { more than secondary education. } \\
\text { Race/ethnicity NR. }\end{array}$ & & & & \\
\hline $\begin{array}{l}\text { Mulder, } 2013^{24} \\
\text { Canada } \\
\mathrm{N}=154\end{array}$ & $\begin{array}{l}400 \mathrm{mg} / \mathrm{d} \mathrm{DHA} \text { vs placebo } \\
\text { (corn and soybean oils) } \\
16 \mathrm{wk} \text { through delivery }\end{array}$ & $\begin{array}{l}\text { BSID-III: Fine motor and gross motor } \\
\text { scales } \\
\text { at } 18 \mathrm{mo}\end{array}$ & $\begin{array}{l}\text { Non-significant: } \\
\text { All main effects (Risk } \\
\text { the placebo group fails } \\
\text { to achieve the } \\
\text { outcome) }\end{array}$ & $\begin{array}{l}\text { - No power calculation } \\
\text { - Pre-registered data } \\
\text { analysis outlined } \\
\text { multiple regression, } \\
\text { NR in paper }\end{array}$ \\
\hline $\begin{array}{l}\text { Mothers were age } \sim 33 y \text { at } \\
\text { enrollment and } 94.4 \% \text { completed } \\
\text { post-secondary eduation. } \\
\text { Race/Ethnicity: } \sim 74 \% \text { White. }\end{array}$ & & & $\begin{array}{l}\text { - Highest quartile fine } \\
\text { motor score } \\
\text { - Highest quartile gross } \\
\text { motor score }\end{array}$ & \\
\hline $\begin{array}{l}\text { Ostadrahimi, } 2018^{25} \\
\text { Iran } \\
\mathrm{N}=146\end{array}$ & $\begin{array}{l}120 \mathrm{mg} / \mathrm{d} \mathrm{DHA}+180 \mathrm{mg} / \mathrm{d} \\
\text { EPA vs placebo (liquid } \\
\text { paraffin) } \\
16-20 \mathrm{wk} \text { through delivery }\end{array}$ & $\begin{array}{l}\text { Parent reported: ASQ-2 Fine and } \\
\text { Gross motor subscales } \\
\text { at } 4 \mathrm{mo} \text { and } 6 \mathrm{mo}\end{array}$ & $\begin{array}{l}\text { Non-significant: } \\
\text { All main effects } \\
\text { - Mean scores } \\
\text { - Subnormal } \\
\text { development }\end{array}$ & $\begin{array}{l}\text { - Pre-registered analysis } \\
\text { plan NR }\end{array}$ \\
\hline
\end{tabular}




\begin{tabular}{|c|c|c|c|c|}
\hline $\begin{array}{l}\text { Study and Participant } \\
\text { Characteristics }\end{array}$ & Intervention (All RCTs) & Outcome(s) & Results & Limitations \\
\hline \multicolumn{5}{|l|}{$\begin{array}{l}\text { Mothers were age } \sim 26 y \text { at } \\
\text { enrollment and } \sim 8 \% \text { completed } \\
>12 \text { y education. } \sim 19 \% \text { had non- } \\
\text { adequate family income. } \\
\text { Race/ethnicity NR. }\end{array}$} \\
\hline $\begin{array}{l}\text { Ramakrishnan, } 2015^{27} \\
\text { Mexico | POSGRAD } \\
\mathrm{N}=730\end{array}$ & $\begin{array}{l}400 \mathrm{mg} / \mathrm{d} \text { DHA vs placebo } \\
\text { (corn and soybean oils) } \\
18-22 \mathrm{wk} \text { through delivery }\end{array}$ & $\begin{array}{l}\text { BSID-II: Psychomotor Scale } \\
\text { at } 18 \mathrm{mo}\end{array}$ & $\begin{array}{l}\text { Non-significant: } \\
\text { All main effects } \\
\text { - Mean score } \\
\text { - Risk of delay }\end{array}$ & $\begin{array}{l}\text { - Pre-registered data } \\
\text { analysis NR }\end{array}$ \\
\hline \multicolumn{5}{|l|}{$\begin{array}{l}\text { Mothers were age } \sim 26 y \text { at } \\
\text { enrollment and } \sim 59 \% \text { completed } \\
\geq 12 \text { y education. }\end{array}$} \\
\hline $\begin{array}{l}\text { Ramakrishnan, } 2016^{26} \\
\text { Mexico | POSGRAD } \\
\text { N=797 } \\
\text { Mothers were age } \sim 26 y \text { at } \\
\text { enrollment and } \sim 58 \% \text { completed } \\
\geq 12 y \text { education. }\end{array}$ & $\begin{array}{l}400 \mathrm{mg} / \mathrm{d} \text { DHA vs placebo } \\
\text { (corn and soybean oils) } \\
18-22 \mathrm{wk} \text { through delivery }\end{array}$ & MSCA: Motor score at $5 y$ & $\begin{array}{l}\text { Non-significant: } \\
\text { All main effects } \\
\text { - Mean raw score } \\
\text { - Mean scale index } \\
\text { score }\end{array}$ & $\begin{array}{l}\text { - Pre-registered data } \\
\text { analysis NR }\end{array}$ \\
\hline \multicolumn{5}{|l|}{ Pregnancy and Lactation } \\
\hline $\begin{array}{l}\text { van Goor, } 2010^{30} \\
\text { The Netherlands } \\
\mathrm{N}=119 \\
\text { Mothers were age } \sim 33 y \text { at } \\
\text { enrollment and } \sim 71 \% \text { completed } \\
\geq 12 y \text { education. Race/ethnicity: } \\
\text { NR. }\end{array}$ & $\begin{array}{l}220 \mathrm{mg} / \mathrm{d} \mathrm{DHA}+220 \mathrm{mg} / \mathrm{d} \\
\text { ARA vs } \\
220 \mathrm{mg} / \mathrm{d} \mathrm{DHA}+\text { placebo } \\
\text { (soy) vs } \\
2 \text { placebos (soy) } \\
14-20 \text { wk through } 3 \mathrm{mo} \\
\text { postpartum }\end{array}$ & $\begin{array}{l}\text { Neonatal neurological classification } \\
\text { at } 2 w k\end{array}$ & $\begin{array}{l}\text { Non-significant: } \\
\text { All main effects } \\
\text { - Mildly abnormal }\end{array}$ & $\begin{array}{l}\text { - }>30 \% \text { attrition before } \\
\text { delivery } \\
\text { - Early trial } \\
\text { discontinuation due to } \\
\text { high incidence mildly } \\
\text { abnormal general } \\
\text { movements at 12wk in } \\
\text { DHA group } \\
\text { - Participant \& } \\
\text { assessors unblinded at } \\
\text { trial discontinuation } \\
\text { - Pre-registered data } \\
\text { analysis NR }\end{array}$ \\
\hline
\end{tabular}




\begin{tabular}{|c|c|c|c|c|}
\hline $\begin{array}{l}\text { Study and Participant } \\
\text { Characteristics }\end{array}$ & Intervention (All RCTs) & Outcome(s) & Results & Limitations \\
\hline & & General movements at $2 \mathrm{wk}$ & Significant: & \\
\hline & & & Favors control & \\
\hline & & & Mildly abnormal & \\
\hline & & & Control vs DHA & \\
\hline & & & Adj $P=0.021$ & \\
\hline & & & $\begin{array}{l}\text { Adj } \beta: 3.867,95 \% \mathrm{Cl}: \\
(1.228,12.173)\end{array}$ & \\
\hline & & General movements at $12 w k$ & Significant: & \\
\hline & & & Favors control & \\
\hline & & & Mildy abnormal & \\
\hline & & & Control vs DHA & \\
\hline & & & Adj $P=0.014$ & \\
\hline & & & $\begin{array}{l}\text { Adj } \beta: 4.121,95 \% \mathrm{Cl}: \\
(1.335,12.719)\end{array}$ & \\
\hline & & $\begin{array}{l}\text { Neurological optimality score (NOS) } \\
\text { at } 12 \mathrm{wk}\end{array}$ & $\begin{array}{l}\text { Non-significant: } \\
\text { All main effects } \\
\text { - Score }\end{array}$ & \\
\hline \multirow{7}{*}{ 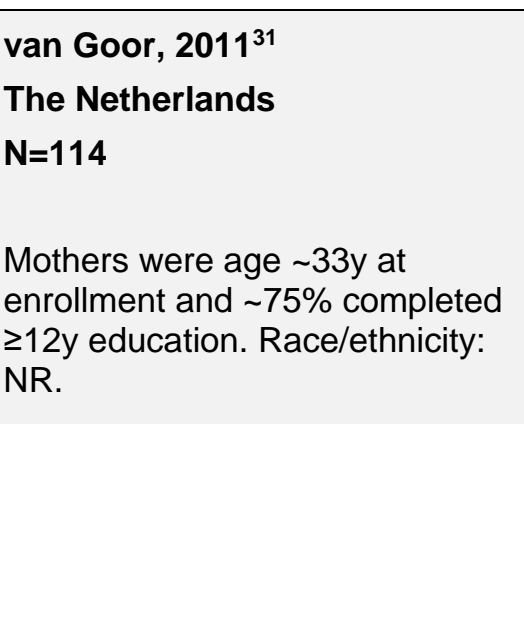 } & $\begin{array}{l}220 \mathrm{mg} / \mathrm{d} \mathrm{DHA}+220 \mathrm{mg} / \mathrm{d} \\
\text { ARA vs }\end{array}$ & \multirow{4}{*}{$\begin{array}{l}\text { Hempel Assessment } \\
\text { at } 18 \mathrm{mo}\end{array}$} & \multirow{4}{*}{$\begin{array}{l}\text { Non-significant: } \\
\text { All main effects } \\
\text { - Neurological } \\
\text { optimality score } \\
\text { - Fluency score } \\
\text { - Normal neurological } \\
\text { condition } \\
\text { - Simple MND } \\
\text { - Complex MND }\end{array}$} & \multirow{4}{*}{$\begin{array}{l}\text { - Unclear power to find } \\
\text { results, but attrition } \\
\text { and reasons } \\
\text { reasonably balanced } \\
\text { - Unclear whether } \\
\text { outcomes would be } \\
\text { affected by unblinded } \\
\text { assessors }\end{array}$} \\
\hline & $\begin{array}{l}220 \mathrm{mg} / \mathrm{d} \text { DHA + placebo } \\
\text { (soy) vs }\end{array}$ & & & \\
\hline & 2 placebos (soy) & & & \\
\hline & $\begin{array}{l}\text { 14-20wk through } 3 \mathrm{mo} \\
\text { postpartum }\end{array}$ & & & \\
\hline & & BSID-II (Dutch edition) & Non-significant: & \multirow{3}{*}{$\begin{array}{l}\text { - BSID not mentioned in } \\
\text { protocol }\end{array}$} \\
\hline & & \multirow[t]{2}{*}{ at $18 \mathrm{mo}$} & All main effects & \\
\hline & & & $\begin{array}{l}\text { - Psychomotor } \\
\text { developmental index }\end{array}$ & \\
\hline
\end{tabular}




\begin{tabular}{|c|c|c|}
\hline & $\begin{array}{l}\text { Non-significant: } \\
\text { All other main effects } \\
\text { - Dominant hand, fast } \\
\text { frequency } \\
\text { - Non-dominant hand, } \\
\text { slow frequency } \\
\text { - Non-dominant hand, } \\
\text { fast frequency }\end{array}$ & \\
\hline $\begin{array}{l}\text { Parent reported: Child Development } \\
\text { Inventory: Gross and fine motor } \\
\text { scales } \\
\text { at } 5 y\end{array}$ & $\begin{array}{l}\text { Non-significant: } \\
\text { All main effects } \\
\text { - Gross motor scale } \\
\text { classification (Normal, } \\
\text { Borderline, Delay) } \\
\text { - Fine motor scale } \\
\text { classification (Normal, } \\
\text { Borderline, Delay) }\end{array}$ & \\
\hline $\begin{array}{l}\text { BSID-II: Psychomotor Scale } \\
\text { at } 2.5 y\end{array}$ & $\begin{array}{l}\text { Significant: } \\
\text { Favors intervention } \\
\text { Adj } P=0.008 \\
\text { Control (Mean } \pm \text { SD): } \\
108.4 \pm 18.9 \\
\text { Intervention: } 116.8 \pm \\
15.2\end{array}$ & $\begin{array}{l}\text { - Statistical power } \\
\text { estimate based on } \\
\text { other outcomes } \\
\text { - Pre-registered data } \\
\text { analysis NR }\end{array}$ \\
\hline
\end{tabular}

$15 w k$ gestation through

\begin{tabular}{l} 
Study and Participant \\
Characteristics \\
\hline Brei, 2017 \\
Germany | INFAT \\
$\mathbf{N}=130$ \\
\\
Mothers were age $\sim 33 y$ at \\
enrollment and $73 \%$ completed \\
$\geq 12 y$ education. Race/Ethnicity: \\
NR.
\end{tabular}

Intervention (All RCTs)

$1020 \mathrm{mg} / \mathrm{d}$ DHA + 180

$\mathrm{mg} / \mathrm{d} E P A+9 \mathrm{mg} / \mathrm{d}$

Vitamin $E$ vs general

nutrition advice

4 mo postpartum
Outcome(s)

Mirror movement ratio

at $5 y$

NR.

\section{Significant:}

Favors intervention

Dominant hand, slow frequency

Adj Est Difference: -

$0.39,95 \% \mathrm{Cl}:(-0.76$, 0.02 )

Non-significant: frequency

Non-dominant hand,

son-dominant hand,

Non-significant:

All main effects

- Gross motor scale classification (Normal,

Borderline, Delay)

classification (Normal, Borderline, Delay)

\section{Lactation only}

Jensen, $2005^{33}$

USA

$\mathrm{N}=160$

$200 \mathrm{mg} / \mathrm{d}$ DHA vs placebo (corn and soybean oils)

$5 \mathrm{~d}$ through $4 \mathrm{mo}$

postpartum

Mothers were age $\sim 32 y$ at

enrollment, with mean education

$16 y$. Race/ethnicity of children:
Limitations

- Reasons for

missingness by group NR

- Results were parentreported

- Pre-registered data analysis NR 


\begin{tabular}{|c|c|c|c|c|}
\hline \multirow{3}{*}{$\begin{array}{l}\text { Study and Participant } \\
\text { Characteristics } \\
77 \% \text { White, } ~ 16 \% \text { Black, } ~ 6 \% \\
\text { Hispanic. }\end{array}$} & Intervention (All RCTs) & Outcome(s) & Results & \multirow[t]{3}{*}{ Limitations } \\
\hline & & & & \\
\hline & & $\begin{array}{l}\text { Gesell Developmental Inventory at } \\
12 \mathrm{mo} \text { and } 2.5 \mathrm{y}\end{array}$ & $\begin{array}{l}\text { Non-significant: } \\
\text { All main effects } \\
\text { - Mean score }\end{array}$ & \\
\hline \multirow{13}{*}{$\begin{array}{l}\text { Jensen, } \mathbf{2 0 1 0}^{32} \\
\text { USA } \\
\text { N=118 } \\
\text { Mothers were age } \sim 32 y \text { at } \\
\text { enrollment, with mean education } \\
\text { 16y. Race/ethnicity of children: } \\
79 \% \text { White, } ~ 14 \% \text { Black, } 6 \% \\
\text { Hispanic. }\end{array}$} & \multirow{6}{*}{$\begin{array}{l}200 \mathrm{mg} / \mathrm{d} \text { DHA vs placebo } \\
\text { (corn and soybean oils) } \\
5 \mathrm{~d} \text { through } 4 \mathrm{mo} \\
\text { postpartum }\end{array}$} & \multirow{6}{*}{$\begin{array}{l}\text { Gross motor: MSCA; K-ABC } \\
\text { at } 5 \mathrm{y}\end{array}$} & Non-significant: & \multirow{13}{*}{$\begin{array}{l}\text { - Statistical power } \\
\text { estimate based on } \\
\text { other outcomes } \\
\text { - Pre-registered data } \\
\text { analysis NR }\end{array}$} \\
\hline & & & All main effects & \\
\hline & & & MSCA & \\
\hline & & & $\begin{array}{l}\text { - Leg Coordination } \\
\text { subscale score }\end{array}$ & \\
\hline & & & $\mathrm{K}-\mathrm{ABC}$ & \\
\hline & & & $\begin{array}{l}\text { - Hand Movement } \\
\text { subscale score }\end{array}$ & \\
\hline & & \multirow{7}{*}{$\begin{array}{l}\text { Fine motor: Purdue Pegboard Test; } \\
\text { Developmental Test of Visual-Motor } \\
\text { Integration-III } \\
\text { at } 5 y\end{array}$} & Non-significant: & \\
\hline & & & All main effects & \\
\hline & & & Purdue Pegboard Test & \\
\hline & & & $\begin{array}{l}\text { - Dominant Hand score } \\
\text { - Non-Dominant Hand } \\
\text { score }\end{array}$ & \\
\hline & & & Developmental Test of & \\
\hline & & & $\begin{array}{l}\text { Visual-Motor } \\
\text { Integration-III }\end{array}$ & \\
\hline & & & $\begin{array}{l}\text { - Motor component } \\
\text { score }\end{array}$ & \\
\hline
\end{tabular}




\section{Visual development \\ Supplementation during pregnancy alone:}

\section{Summary:}

Five RCTs examined the effects of omega- 3 fatty acid supplementation during pregnancy alone on visual development in the child (ages 1 day to 12 months) ${ }^{17,21,24,28,29}$ (Table 5). All 5 studies found no effect of treatment on at least one measure of visual development among children assessed from the neonatal period through 12 months. Two RCTs found statistically significant, favorable effects of omega-3 fatty acid supplementation on one measure of visual acuity in the child at approximately age 2 months. ${ }^{17,24}$

Assessment of the evidence ${ }^{x i}$ :

The evidence was characterized by mixed results, samples that may not reflect the diversity of the general U.S. population, and risk of bias due to deviations from the intended intervention and selection of the reported results (Table 8). Given these limitations, insufficient evidence existed to determine the relationship between omega-3 fatty acid supplementation during pregnancy alone and visual development in the child and the body of evidence was rated 'grade not assignable.'

\section{Supplementation during both pregnancy and lactation:}

\section{Summary:}

No studies examined the effects of omega-3 fatty acid supplementation during both pregnancy and lactation on visual development in the child, and therefore a grade was not assignable.

\section{Supplementation during lactation alone:}

Summary:

One RCT examined the effect of omega-3 fatty acid supplementation during lactation alone on visual development in the child ${ }^{32,33}$ (Table 5). Jensen et al reported unfavorable outcomes for a single, electrophysiological measure of visual acuity at ages 4 months and 8 months, ${ }^{33}$ but no association with another electrophysiological measure at the same ages. Additional results revealed no association with other measures of visual development at ages 4 months, 8 months, and 5 years. ${ }^{32,33}$

Assessment of the evidence:

The entire body of evidence consisted of a single study with concerns regarding statistical power to detect effects in these secondary outcomes, risk of bias due to selection of reported results (Table 8), and a sample that may not reflect the diversity of the general U.S. population. Therefore, insufficient evidence existed to determine the relationship between omega-3 fatty acid supplementation during lactation alone and visual development in the child, and the body of evidence was rated 'grade not assignable.'

\footnotetext{
${ }^{x i}$ A detailed description of the methodology used for grading the strength of the evidence is available on the NESR website: https://nesr.usda.gov/2020-dietary-guidelines-advisory-committee-systematicreviews and in Part $\mathrm{C}$ of the following reference: Dietary Guidelines Advisory Committee. 2020. Scientific Report of the 2020 Dietary Guidelines Advisory Committee: Advisory Report to the Secretary of Agriculture and the Secretary of Health and Human Services. U.S. Department of Agriculture, Agricultural Research Service, Washington, DC.
} 


\section{Table 5. Description of evidence on relationship between omega-3 fatty acid supplementation and visual development ${ }^{x i i}$}

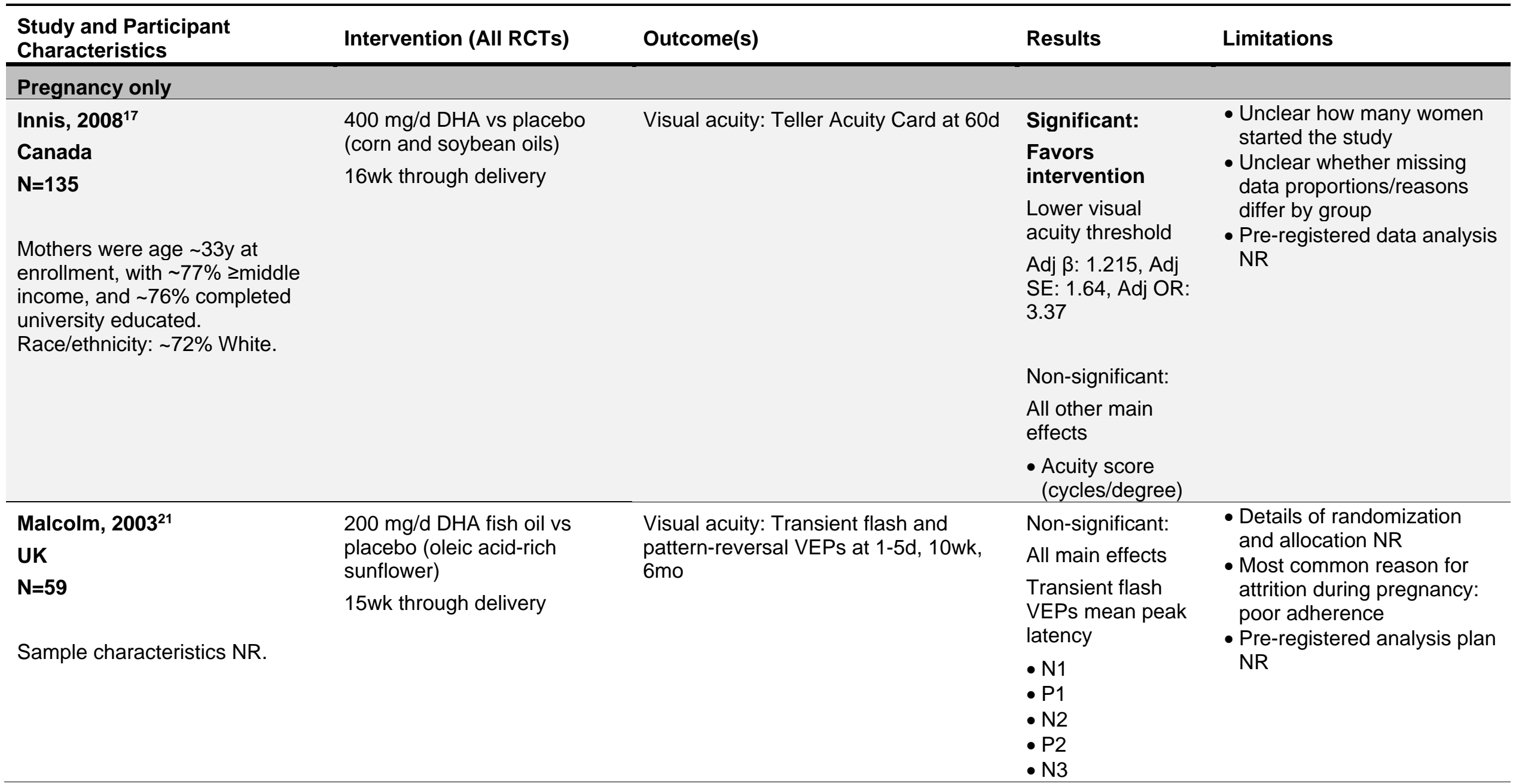

xii Adj: adjusted; Cl: confidence interval; DHA: docosahexaenoic acid; DOMInO: DHA to Optimize Mother Infant Outcome; EPA: eicosapentaenoic acid; NR: not reported; OR: odds ratio; POSGRAD: Prenatal Omega 3 Supplementation on child Growth and Development; RCT: randomized controlled trial; SE: standard error; VEP: visual evoked potentials 


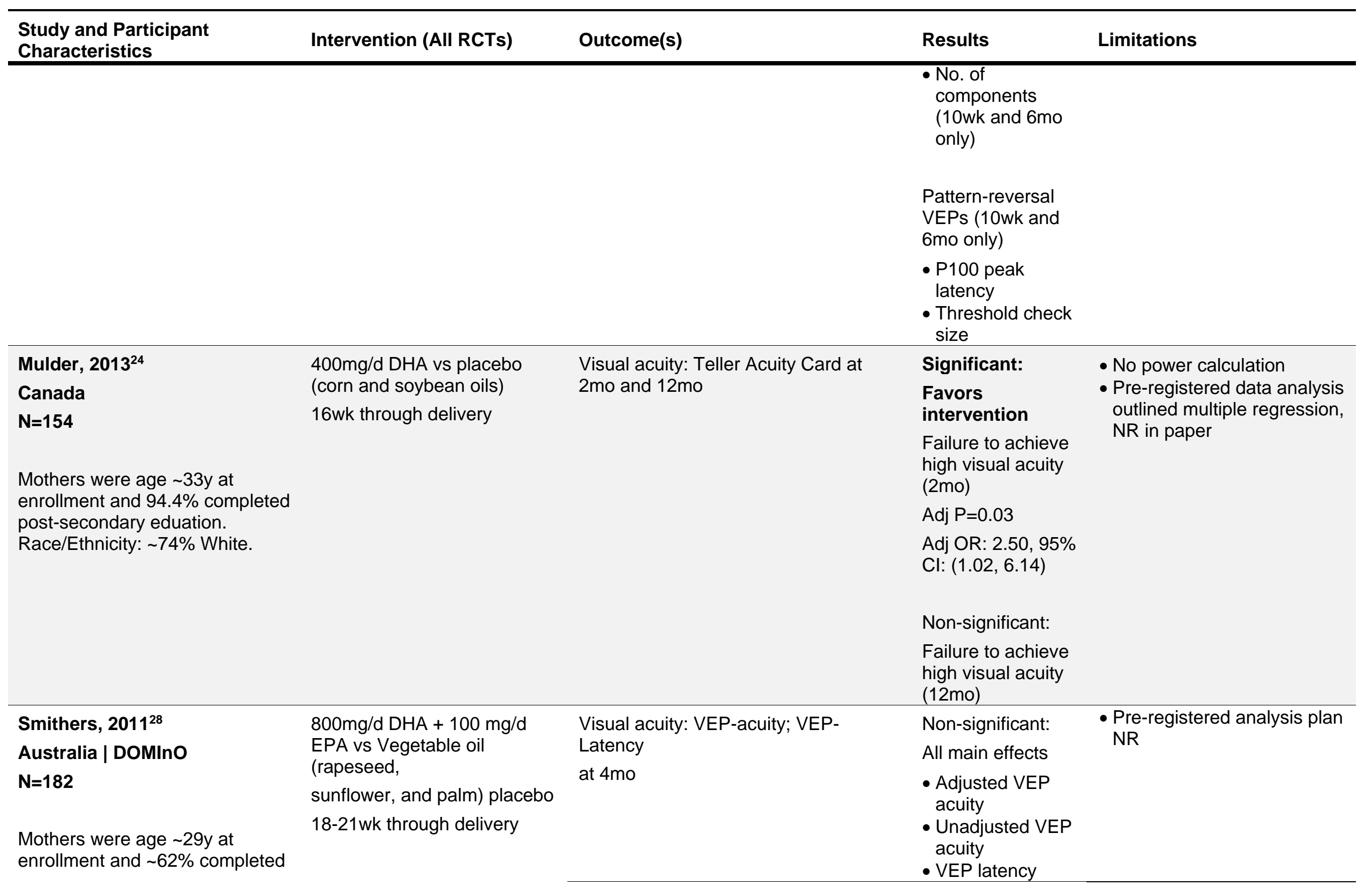




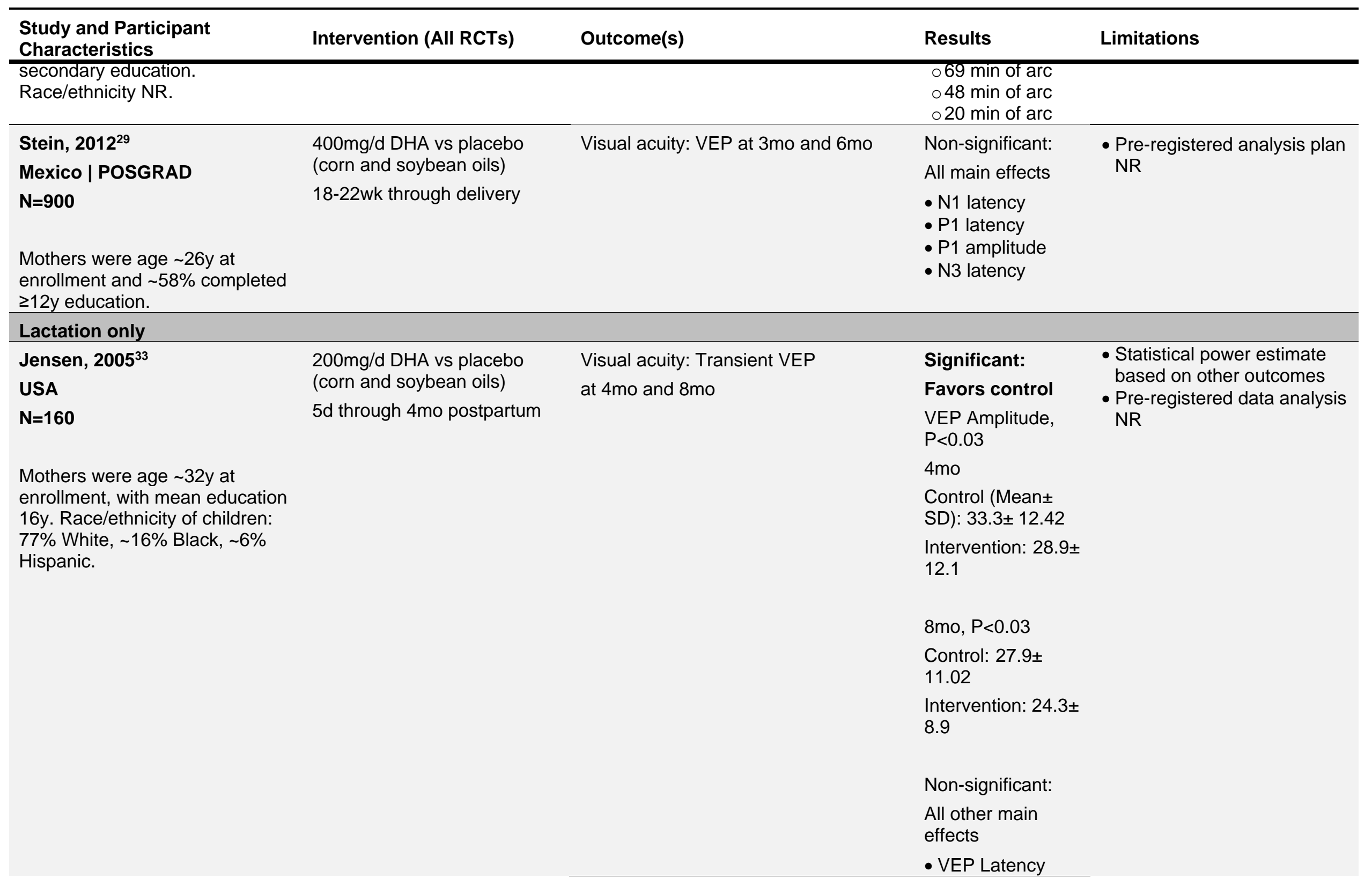




\begin{tabular}{|c|c|c|c|c|}
\hline $\begin{array}{l}\text { Study and Participant } \\
\text { Characteristics }\end{array}$ & Intervention (All RCTs) & Outcome(s) & Results & Limitations \\
\hline & & $\begin{array}{l}\text { Visual acuity: Teller Acuity Card } \\
\text { at } 4 \mathrm{mo} \text { and } 8 \mathrm{mo}\end{array}$ & $\begin{array}{l}\text { Non-significant: } \\
\text { All main effects } \\
\text { - Score } \\
\text { (cycle/degree) }\end{array}$ & \\
\hline & & $\begin{array}{l}\text { Visual acuity: Sweep VEP } \\
\text { at } 4 \mathrm{mo}\end{array}$ & $\begin{array}{l}\text { Non-significant: } \\
\text { All main effects } \\
\text { - Score } \\
\text { (cycle/degree) }\end{array}$ & \\
\hline \multirow[t]{4}{*}{$\begin{array}{l}\text { Jensen, } \mathbf{2 0 1 0}^{32} \\
\text { USA } \\
\mathbf{N}=\mathbf{1 1 8} \\
\text { Mothers were age } \sim 32 y \text { at } \\
\text { enrollment, with mean education } \\
\text { 16y. Race/ethnicity of children: } \\
79 \% \text { White, } \sim 14 \% \text { Black, } ~ 6 \% \\
\text { Hispanic. }\end{array}$} & \multirow[t]{4}{*}{$\begin{array}{l}200 \mathrm{mg} / \mathrm{d} \text { DHA vs placebo } \\
\text { (corn and soybean oils) } \\
5 \mathrm{~d} \text { through } 4 \text { mo postpartum }\end{array}$} & $\begin{array}{l}\text { Visual acuity: VEP } \\
\text { at } 5 y\end{array}$ & $\begin{array}{l}\text { Non-significant: } \\
\text { All main effects } \\
\text { - VEP Amplitude, } \\
\text { P=0.06 } \\
\text { OPlacebo > DHA } \\
\text { - VEP Latency } \\
\text { - Sweep VEP } \\
\text { acuity } \\
\text { (cycle/degree) }\end{array}$ & \multirow[t]{4}{*}{$\begin{array}{l}\text { - Statistical power estimate } \\
\text { based on other outcomes } \\
\text { - Pre-registered data analysis } \\
\text { NR }\end{array}$} \\
\hline & & $\begin{array}{l}\text { Visual acuity/Stereoacuity: Bailey- } \\
\text { Lovie chart; Titmus Fly Stereotest } \\
\text { at } 5 y\end{array}$ & $\begin{array}{l}\text { Non-significant: } \\
\text { All main effects } \\
\text { Bailey-Lovie chart } \\
\text { - Right eye no. } \\
\text { correct letters } \\
\text { - Left eye no. } \\
\text { correct letters }\end{array}$ & \\
\hline & & & $\begin{array}{l}\text { Titmus Fly } \\
\text { Stereotest }\end{array}$ & \\
\hline & & & $\begin{array}{l}\text { - Smallest target } \\
\text { identified }\end{array}$ & \\
\hline
\end{tabular}




\section{Social-emotional development \\ Supplementation during pregnancy alone:}

\section{Summary:}

Seven RCTs examined the effect of omega-3 fatty acid supplementation during pregnancy alone on social-emotional development in the child (ages 1 week to 7 years). $6,7,11,12,18$ 20,22,25-27 Two found statistically significant effects (Table 6). ${ }^{11,18,20}$ In 1 study, children of mothers in the omega-3 fatty acid supplemented group were more likely to have higher total difficulties or hyperactivity on a parent-reported measure of child behavior at 4 years, but supplementation had no effect on other parameters measured with the same tool. ${ }^{20} \mathrm{At}$ 7 years, using an age-appropriate version of the same tool, the authors reported that the total score indicated unfavorable outcomes for children of mothers in the supplemented group. ${ }^{11}$ Another study revealed that omega-3 fatty acid supplementation resulted in a more attenuated (favorable) stress response at 3 months. ${ }^{18}$ The remaining studies did not report any statistically significant results. $6,7,12,22,25-27$

Assessment of the evidence ${ }^{x i i}$ :

Given the mixed results and concerns regarding the risk of bias due to parent-reported outcomes (Table 8), insufficient evidence existed to determine the relationship between omega-3 fatty acid supplementation during pregnancy alone and social-emotional development in the child, and therefore the body of evidence was rated 'grade not assignable.'

\section{Supplementation during both pregnancy and lactation:}

Summary:

One RCT reported no effect of omega-3 fatty acid supplementation during both pregnancy and lactation on a parent-reported measure of social-emotional development in the child at age 4 years and 5 years (Table 6$){ }^{1}$

Assessment of the evidence:

The entire body of evidence consisted of a single study with concerns regarding statistical power to detect effects in these secondary outcomes, risk of bias concerns due to parentreported outcomes (Table 8), and limited information on the generalizability of results to the general U.S. population. Therefore, insufficient evidence existed to determine the relationship between omega-3 fatty acid supplementation during both pregnancy and lactation and social-emotional development in the child, and the body of evidence was rated 'grade not assignable.'

\section{Supplementation during lactation alone:}

\section{Summary:}

No studies examined the effect of omega- 3 fatty acid supplementation during lactation alone on social-emotional development in the child, and therefore a grade was not assignable.

\footnotetext{
xiii A detailed description of the methodology used for grading the strength of the evidence is available on the NESR website: https://nesr.usda.gov/2020-dietary-guidelines-advisory-committee-systematicreviews and in Part $\mathrm{C}$ of the following reference: Dietary Guidelines Advisory Committee. 2020. Scientific Report of the 2020 Dietary Guidelines Advisory Committee: Advisory Report to the Secretary of Agriculture and the Secretary of Health and Human Services. U.S. Department of Agriculture, Agricultural Research Service, Washington, DC.
} 
Table 6. Description of evidence on relationship between omega-3 fatty acid supplementation and social-emotional development ${ }^{\mathrm{xiv}}$

\begin{tabular}{|c|c|c|c|c|}
\hline $\begin{array}{l}\text { Study and Participant } \\
\text { Characteristics }\end{array}$ & Intervention (All RCTs) & Outcome(s) & Results & Limitations \\
\hline \multicolumn{5}{|l|}{ Pregnancy only } \\
\hline $\begin{array}{l}\text { Colombo, } 2019^{6} \\
\text { USA } \\
\mathrm{N}=161 \\
\text { Mothers were age } ~ 26 y \text { at } \\
\text { enrollment, with mean income } \\
<\$ 46 \mathrm{~K} \text { and } \sim 14 \mathrm{y} \text { education. } \\
\text { Race/Ethnicity: 6\% Hispanic, 31\% } \\
\text { Black. }\end{array}$ & $\begin{array}{l}600 \mathrm{mg} / \mathrm{d} \text { DHA vs placebo } \\
\text { (corn and soybean oils) } \\
\sim 14.5 \mathrm{wk} \text { through delivery }\end{array}$ & $\begin{array}{l}\text { Behavior--Parent reported: BASC } \\
\text { at } 36 \mathrm{mo}, 48 \mathrm{mo}, 60 \mathrm{mo}, 72 \mathrm{mo}\end{array}$ & $\begin{array}{l}\text { Non-significant: } \\
\text { All main effects } \\
\text { - Externalizing } \\
\text { Problems } \\
\text { - Internalizing Problems } \\
\text { - Behavioral Symptoms } \\
\text { - Adaptive Skills }\end{array}$ & $\begin{array}{l}\text { - Results parent- } \\
\text { reported } \\
\text { - More outcomes } \\
\text { reported in the paper } \\
\text { than on the clinical } \\
\text { trials registry } \\
\text { - Pre-registered data } \\
\text { analysis plan NR }\end{array}$ \\
\hline $\begin{array}{l}\text { Dunstan, 2008 } \\
\text { Australia } \\
\mathrm{N}=\mathbf{7 2} \\
\text { Mothers were age } \sim 32 \mathrm{y} \text { at } \\
\text { enrollment and } \sim 73 \% \text { completed } \\
\geq 12 \mathrm{y} \text { education. Race/Ethnicity: } \\
\text { 100\% White. }\end{array}$ & $\begin{array}{l}2.2 \mathrm{~g} / \mathrm{d} \text { DHA }+1.1 \mathrm{~g} / \mathrm{d} \text { EPA vs } \\
\text { placebo (olive oil) } \\
20 \mathrm{wk} \text { through delivery }\end{array}$ & $\begin{array}{l}\text { Behavior--Parent Reported: CBCL: } \\
1.5-5 \mathrm{y} \\
\text { at } 2.5 \mathrm{y}\end{array}$ & $\begin{array}{l}\text { Non-significant: } \\
\text { All main effects } \\
\text { - Internalizing scale } \\
\text { - Externalizing scale } \\
\text { - Total problem } \\
\text { behavioral scale }\end{array}$ & $\begin{array}{l}\text { - Results parent- } \\
\text { reported } \\
\text { - Probable differences in } \\
\text { reasons for attrition, no } \\
\text { power calculation for } \\
\text { neurobehavioral } \\
\text { results } \\
\text { - Pre-registered data } \\
\text { analysis plan NR }\end{array}$ \\
\hline $\begin{array}{l}\text { Gould, } 2017^{11} \\
\text { Australia | DOMInO } \\
\mathrm{N}=543\end{array}$ & $\begin{array}{l}800 \mathrm{mg} / \mathrm{d} \mathrm{DHA}+100 \mathrm{mg} / \mathrm{d} \\
\text { EPA vs Vegetable oil } \\
\text { (rapeseed, } \\
\text { sunflower, and palm) placebo } \\
18-21 \mathrm{wk} \text { through delivery }\end{array}$ & $\begin{array}{l}\text { Behavior--Parent reported: SDQ } \\
\text { at } 7 y\end{array}$ & $\begin{array}{l}\text { Significant: } \\
\text { Favors control } \\
\text { Total difficulties score } \\
\text { Adj } P=0.02 \\
\text { Ref: Control }\end{array}$ & $\begin{array}{l}\text { - Results parent- } \\
\text { reported }\end{array}$ \\
\hline
\end{tabular}

xiv Adj: adjusted; ASQ: Ages and Stages Questionnaire; BASC: Behavioral Assessment System for Children; BSID: Bayley Scales of Infant Development; CBCL: Child Behavior Checklist; Cl: confidence interval; DHA: docosahexaenoic acid; DOMInO: DHA to Optimize Mother Infant Outcome; EPA:

eicosapentaenoic acid; ETA: eicosatetranoic acid; FFSF: Face-to-Face Still-Face task; INFAT: The Impact of the Nutritional Fatty Acids During Pregnancy and Lactation for Early Human Adipose Tissue Development; NBAS: Neonatal Behavioral Assessment Scale; NR: not reported; POSGRAD: Prenatal

Omega 3 Supplementation on child Growth and Development; RCT: randomized controlled trial; SDQ: Strengths and Difficulties Questionnaire 


\begin{tabular}{|c|c|c|c|c|}
\hline $\begin{array}{l}\text { Study and Participant } \\
\text { Characteristics }\end{array}$ & Intervention (All RCTs) & Outcome(s) & Results & Limitations \\
\hline $\begin{array}{l}\text { Mothers were age } \sim 30 y \text { at } \\
\text { enrollment and } \sim 66 \% \text { completed } \\
\text { secondary education. } \\
\text { Race/ethnicity NR. }\end{array}$ & & & $\begin{array}{l}\text { Adj Mean Difference: } \\
\text { 1.09, 95\% Cl: }(0.18, \\
2.00)\end{array}$ & \\
\hline $\begin{array}{l}\text { Gustafson, } \mathbf{2 0 1 3}^{\mathbf{1 2}} \\
\text { USA } \\
\mathrm{N}=\mathbf{4 4} \\
\text { Mothers were age } 26 y \text { at } \\
\text { enrollment and completed } \sim 14 \mathrm{y} \\
\text { education. Race/Ethnicity: } 37.3 \% \\
\text { Black, } 46.3 \% \text { White, } 13.4 \% \\
\text { Hispanic, 3\% Asian. }\end{array}$ & $\begin{array}{l}600 \mathrm{mg} / \mathrm{d} \mathrm{DHA} \text { vs placebo } \\
\text { (corn and soybean oils) } \\
12-20 \mathrm{wk} \text { through delivery }\end{array}$ & $\begin{array}{l}\text { NBAS: State organization, State } \\
\text { regulation scales } \\
\text { at } 1 \mathrm{wk}\end{array}$ & $\begin{array}{l}\text { Non-significant: } \\
\text { All main effects } \\
\text { - State organization } \\
\text { - State regulation } \\
\text { scales }\end{array}$ & $\begin{array}{l}\text { - No power calculation } \\
\text { - Pre-registered analysis } \\
\text { plan NR }\end{array}$ \\
\hline $\begin{array}{l}\text { Keenan, } 2016^{18} \\
\text { USA } \\
\text { N=49 } \\
\text { Age } 20-30 y .100 \% \text { Medicaid } \\
\text { eligible. Race/Ethnicity: } 100 \% \\
\text { Black. }\end{array}$ & $\begin{array}{l}450 \mathrm{mg} / \mathrm{d} \mathrm{DHA}+40 \mathrm{mg} / \mathrm{d} \\
\mathrm{DPA}+40 \mathrm{mg} / \mathrm{d} \text { ETA }+90 \\
\mathrm{mg} / \mathrm{d} \text { EPA }+10 \mathrm{mg} / \mathrm{d} \text { Vitamin } \\
\text { E vs } 990 \mathrm{mg} / \mathrm{d} \text { soybean oil }+ \\
16.5 \mathrm{mg} / \mathrm{d} \text { Vitamin } \mathrm{E}+10 \\
\mathrm{mg} / \mathrm{d} \mathrm{EPA}+10 \mathrm{mg} / \mathrm{d} \text { DHA } \\
16-21 \mathrm{wk} \text { for } 6 \mathrm{wk}\end{array}$ & $\begin{array}{l}\text { Behavior--Stress reactivity: FFSF } \\
\text { cortisol response at } 3 \mathrm{mo}\end{array}$ & $\begin{array}{l}\text { Significant: } \\
\text { Favors intervention } \\
\text { Adj } P=0.018 \\
F=5.36\end{array}$ & $\begin{array}{l}\text { - Reasons for } \\
\text { missingness by group } \\
\text { NR } \\
\text { - Pre-registered data } \\
\text { analysis plan NR }\end{array}$ \\
\hline $\begin{array}{l}\text { Makrides, } 2010^{19} \\
\text { Australia | DOMInO } \\
\mathrm{N}=694 \\
\text { Mothers were age } \sim 29 \mathrm{y} \text { at } \\
\text { enrollment and } \sim 68 \% \text { completed } \\
\text { more than secondary education. } \\
\text { Race/ethnicity NR. }\end{array}$ & $\begin{array}{l}800 \mathrm{mg} / \mathrm{d} \mathrm{DHA}+100 \mathrm{mg} / \mathrm{d} \\
\text { EPA vs Vegetable oil placebo } \\
18-21 \mathrm{wk} \text { through delivery }\end{array}$ & $\begin{array}{l}\text { BSID-III: Social-emotional scale } \\
\text { Adaptive Behavioral subscales } \\
\text { at } 18 \mathrm{mo}\end{array}$ & $\begin{array}{l}\text { Non-significant: } \\
\text { All main effects } \\
\text { - Social-emotional } \\
\text { Standardized Score } \\
\text { - Adaptive Behavior } \\
\text { Standardized Score }\end{array}$ & $\begin{array}{l}\text { - Pre-registered analysis } \\
\text { plan NR }\end{array}$ \\
\hline $\begin{array}{l}\text { Makrides, } 2014^{20} \\
\text { Australia | DOMInO } \\
\mathrm{N}=646\end{array}$ & $\begin{array}{l}800 \mathrm{mg} / \mathrm{d} \mathrm{DHA}+100 \mathrm{mg} / \mathrm{d} \\
\text { EPA vs Vegetable oil } \\
\text { (rapeseed, } \\
\text { sunflower, and palm) placebo }\end{array}$ & $\begin{array}{l}\text { Behavior--Parent Reported: SDQ } \\
\text { scales, subscales } \\
\text { at } 4 y\end{array}$ & $\begin{array}{l}\text { Significant: } \\
\text { Favors control } \\
\text { Total difficulties }\end{array}$ & $\begin{array}{l}\text { - Results parent- } \\
\text { reported } \\
\text { - Pre-registered analysis } \\
\text { plan NR }\end{array}$ \\
\hline
\end{tabular}




\begin{tabular}{|c|c|c|c|c|}
\hline $\begin{array}{l}\text { Study and Participant } \\
\text { Characteristics }\end{array}$ & Intervention (All RCTs) & Outcome(s) & Results & Limitations \\
\hline \multirow{10}{*}{$\begin{array}{l}\text { Mothers were age } \sim 29 y \text { at } \\
\text { enrollment and } \sim 68 \% \text { completed } \\
\text { more than secondary education. } \\
\text { Race/ethnicity NR. }\end{array}$} & \multirow[t]{10}{*}{ 18-21wk through delivery } & & \multirow{3}{*}{\multicolumn{2}{|c|}{$\begin{array}{l}\text { Adj } P=0.04 \\
\text { Ref: Control } \\
\text { Adj Mean Difference: } \\
0.63,95 \% \mathrm{Cl}:(0.03, \\
1.23)\end{array}$}} \\
\hline & & & & \\
\hline & & & & \\
\hline & & & \multirow{4}{*}{\multicolumn{2}{|c|}{$\begin{array}{l}\text { Hyperactivity } \\
\text { Adj P=0.04 } \\
\text { Ref: Control } \\
\text { Adj Mean Difference: } \\
0.30,95 \% \mathrm{Cl} \text { : } 0.01 \text {, } \\
0.59)\end{array}$}} \\
\hline & & & & \\
\hline & & & & \\
\hline & & & & \\
\hline & & & \multirow{2}{*}{\multicolumn{2}{|c|}{$\begin{array}{l}\text { Non-significant: } \\
\text { All other main effects }\end{array}$}} \\
\hline & & & & \\
\hline & & & \multicolumn{2}{|l|}{$\begin{array}{l}\text { - Emotional Symptoms } \\
\text { - Conduct Problems } \\
\text { - Peer Problems } \\
\text { - Prosocial Behavior } \\
\text { - Impact }\end{array}$} \\
\hline Meldrum, 2015²2 & \multirow{3}{*}{$\begin{array}{l}2.2 \mathrm{~g} / \mathrm{d} \mathrm{DHA}+1.1 \mathrm{~g} / \mathrm{d} \text { EPA vs } \\
\text { placebo (olive oil) } \\
20 \mathrm{wk} \text { through delivery }\end{array}$} & \multirow{3}{*}{$\begin{array}{l}\text { Behavior--Parent, Child Reported: } \\
\text { CBCL } \\
\text { at } 12 \mathrm{y}\end{array}$} & Non-significant: & \multirow{3}{*}{$\begin{array}{l}\text { - Results parent- } \\
\text { reported } \\
\text { - Among those followed } \\
\text { to } 12 y \text {, birth weight } \\
\text { differed by treatment } \\
\text { group } \\
\text { - Possible differences in } \\
\text { reasons for attrition } \\
\text { - No power calculation, } \\
\text { Likely under-powered }\end{array}$} \\
\hline $\mathrm{N}=48$ & & & Parent-Report & \\
\hline $\begin{array}{l}\text { Mothers were age } \sim 32 y \text { at } \\
\text { enrollment and } \sim 73 \% \text { completed } \\
\geq 12 y \text { education. Race/Ethnicity: } \\
100 \% \text { White. }\end{array}$ & & & $\begin{array}{l}\text { - Internalizing } \\
\text { Behaviors } \\
\text { - Externalizing } \\
\text { Behaviors } \\
\text { - Total Behaviors score } \\
\text { - Total Competence } \\
\text { score }\end{array}$ & \\
\hline
\end{tabular}




\begin{tabular}{|c|c|c|c|c|}
\hline $\begin{array}{l}\text { Study and Participant } \\
\text { Characteristics }\end{array}$ & Intervention (All RCTs) & Outcome(s) & Results & Limitations \\
\hline & & & $\begin{array}{l}\text { Child-Self Report } \\
\text { - Internalizing } \\
\text { Behaviors } \\
\text { - Externalizing } \\
\text { Behaviors } \\
\text { - Total Behaviors score } \\
\text { - Total Competence } \\
\text { score }\end{array}$ & \\
\hline $\begin{array}{l}\text { Ostadrahimi, } \mathbf{2 0 1 8 ^ { 2 5 }} \\
\text { Iran } \\
\mathrm{N}=146 \\
\text { Mothers were age } \sim 26 y \text { at } \\
\text { enrollment and } \sim 8 \% \text { completed } \\
>12 \text { y education. } ~ 19 \% \text { had non- } \\
\text { adequate family income. } \\
\text { Race/ethnicity NR. }\end{array}$ & $\begin{array}{l}120 \mathrm{mg} / \mathrm{d} \mathrm{DHA}+180 \mathrm{mg} / \mathrm{d} \\
\text { EPA vs placebo (liquid } \\
\text { paraffin) } \\
16-20 \mathrm{wk} \text { through delivery }\end{array}$ & $\begin{array}{l}\text { Behavior--Parent reported: ASQ-2 } \\
\text { Personal-social subscale at } 4 \mathrm{mo} \text { and } \\
6 \mathrm{mo}\end{array}$ & $\begin{array}{l}\text { Non-significant: } \\
\text { All main effects } \\
\text { - Mean score } \\
\text { - Subnormal } \\
\text { development }\end{array}$ & $\begin{array}{l}\text { - Behavioral data } \\
\text { parent-reported data } \\
\text { - Pre-registered analysis } \\
\text { plan NR }\end{array}$ \\
\hline $\begin{array}{l}\text { Ramakrishnan, } 2015^{27} \\
\text { Mexico | POSGRAD } \\
\mathrm{N}=730\end{array}$ & \multirow[t]{2}{*}{$\begin{array}{l}400 \mathrm{mg} / \mathrm{d} \text { DHA vs placebo } \\
\text { (corn and soybean oils) } \\
18-22 \text { wk through delivery }\end{array}$} & \multirow[t]{2}{*}{$\begin{array}{l}\text { BSID-II: Behavior Rating Scale at } \\
\text { 18mo }\end{array}$} & $\begin{array}{l}\text { Non-significant: } \\
\text { All main effects } \\
\text { - Mean score } \\
\text { - Risk of delay }\end{array}$ & \multirow[t]{2}{*}{$\begin{array}{l}\text { - Results parent- } \\
\text { reported } \\
\text { - Pre-registered data } \\
\text { analysis NR }\end{array}$} \\
\hline $\begin{array}{l}\text { Mothers were age } \sim 26 y \text { at } \\
\text { enrollment and } \sim 59 \% \text { completed } \\
\geq 12 y \text { education. }\end{array}$ & & & & \\
\hline $\begin{array}{l}\text { Mothers were age } \sim 26 y \text { at } \\
\text { enrollment and } \sim 58 \% \text { completed } \\
\geq 12 y \text { education. }\end{array}$ & $\begin{array}{l}400 \mathrm{mg} / \mathrm{d} \text { DHA vs placebo } \\
\text { (corn and soybean oils) } \\
18-22 w k \text { through delivery }\end{array}$ & $\begin{array}{l}\text { Behavior--Parent Reported: BASC-2 } \\
\text { at } 5 y\end{array}$ & $\begin{array}{l}\text { Non-significant: } \\
\text { All main effects } \\
\text { - Externalizing } \\
\text { problems composite } \\
\text { o Hyperactivity } \\
\text { o Aggression } \\
\text { - Internalizing problems } \\
\text { composite } \\
\text { ○Anxiety }\end{array}$ & $\begin{array}{l}\text { - Results parent- } \\
\text { reported } \\
\text { - Pre-registered data } \\
\text { analysis NR }\end{array}$ \\
\hline
\end{tabular}




\begin{tabular}{|c|c|c|c|c|}
\hline $\begin{array}{l}\text { Study and Participant } \\
\text { Characteristics }\end{array}$ & Intervention (All RCTs) & Outcome(s) & Results & Limitations \\
\hline & & & 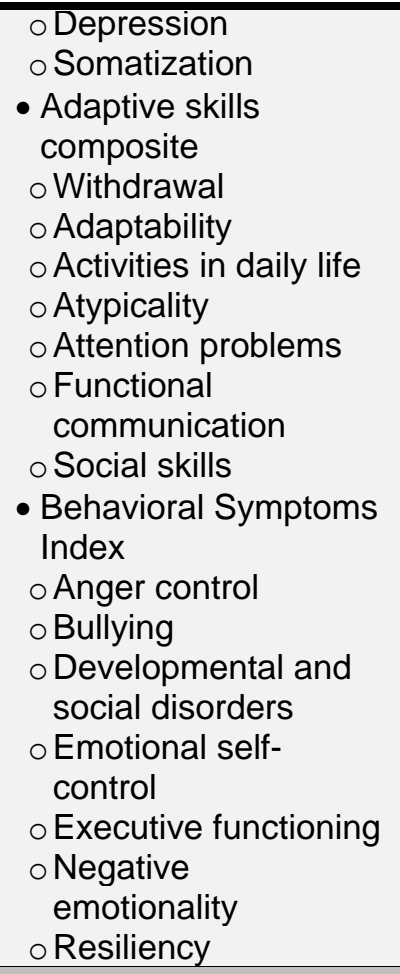 & \\
\hline \multicolumn{5}{|l|}{ Pregnancy and Lactation } \\
\hline $\begin{array}{l}\text { Brei, } 2017 \text { 1 } \\
\text { Germany | INFAT } \\
\mathrm{N}=130 \\
\text { Mothers were age } \sim 33 y \text { at } \\
\text { enrollment and } 73 \% \text { completed } \\
\geq 12 y \text { education. Race/Ethnicity: } \\
\text { NR. }\end{array}$ & $\begin{array}{l}1020 \mathrm{mg} / \mathrm{d} \text { DHA }+180 \mathrm{mg} / \mathrm{d} \\
\text { EPA }+9 \mathrm{mg} / \mathrm{d} \text { Vitamin } \mathrm{E} \text { vs } \\
\text { general nutrition advice } \\
15 \text { wk gestation through } 4 \mathrm{mo} \\
\text { postpartum }\end{array}$ & $\begin{array}{l}\text { Behavior--Parent reported: Child } \\
\text { Development Inventory: Social, self- } \\
\text { help scales } \\
\text { at } 4 y \text { and } 5 y\end{array}$ & $\begin{array}{l}\text { Non-significant: } \\
\text { All main effects } \\
\text { - Social scale } \\
\text { classification (Normal, } \\
\text { Borderline, Delay) } \\
\text { - Self help scale } \\
\text { classification (Normal, } \\
\text { Borderline, Delay) }\end{array}$ & $\begin{array}{l}\text { - Reasons for } \\
\text { missingness by group } \\
\text { NR } \\
\text { - Results were parent- } \\
\text { reported } \\
\text { - Pre-registered data } \\
\text { analysis NR }\end{array}$ \\
\hline
\end{tabular}




\section{Academic performance}

Supplementation during pregnancy alone:

Summary:

A single RCT examined the effect of omega-3 fatty acid supplementation during pregnancy alone on academic performance in the child and found no effect on a measure of reading, spelling, and math computation at age 7 years (Table 7). ${ }^{11}$

Assessment of the evidence ${ }^{x v}$ :

The entire body of evidence consisted of a single study in a sample that may not reflect the diversity of the general U.S. population. Therefore, insufficient evidence existed to determine the relationship between omega-3 fatty acid supplementation during pregnancy alone and academic performance in the child, and the body of evidence was rated 'grade not assignable.'

\section{Supplementation during both pregnancy and lactation:}

\section{Summary:}

No studies examined the effect of omega-3 fatty acid supplementation during both pregnancy and lactation on academic performance in the child, and therefore a grade was not assignable.

\section{Supplementation during lactation alone:}

\section{Summary:}

No studies examined the effect of omega- 3 fatty acid supplementation during lactation alone on academic performance in the child, and therefore a grade was not assignable.

\section{Anxiety}

\section{Summary:}

No studies examined the effect of omega-3 fatty acid supplementation during pregnancy and/or lactation on anxiety in the child, and therefore a grade was not assignable.

\section{Depression}

\section{Summary:}

No studies examined the effect of omega-3 fatty acid supplementation during pregnancy and/or lactation on depression in the child, and therefore a grade was not assignable.

\section{ADD/ADHD}

\section{Supplementation during pregnancy alone:}

Summary:

A single RCT examined the effect of omega-3 fatty acid supplementation during pregnancy alone on risk of ADD/ADHD in the child. The results showed no effect at age 4 years, ${ }^{10}$

\footnotetext{
${ }^{x v}$ A detailed description of the methodology used for grading the strength of the evidence is available on the NESR website: https://nesr.usda.gov/2020-dietary-guidelines-advisory-committee-systematicreviews and in Part C of the following reference: Dietary Guidelines Advisory Committee. 2020. Scientific Report of the 2020 Dietary Guidelines Advisory Committee: Advisory Report to the Secretary of Agriculture and the Secretary of Health and Human Services. U.S. Department of Agriculture, Agricultural Research Service, Washington, DC.
} 
and a higher risk of ADHD among children of mothers in the treatment group at 7 years (Table 7). ${ }^{11}$

Assessment of the evidence:

The entire body of evidence consisted of a single study in a sample that may not reflect the diversity of the general U.S. population. Therefore, insufficient evidence existed to determine the relationship between omega- 3 fatty acid supplementation during pregnancy alone and ADD/ADHD in the child, and a grade was not assignable.

\section{Supplementation during both pregnancy and lactation:}

Summary:

No studies examined the effect of omega-3 fatty acid supplementation during both pregnancy and lactation on risk of ADD/ADHD in the child, and therefore a grade was not assignable.

\section{Supplementation during lactation alone:}

\section{Summary:}

No studies examined the effect of omega- 3 fatty acid supplementation during lactation alone on risk of ADD/ADHD in the child, and therefore a grade was not assignable.

\section{Autism spectrum disorder}

\section{Supplementation during pregnancy alone:}

\section{Summary:}

One $\mathrm{RCT}^{10}$ and $1 \mathrm{PCS}^{16}$ examined the effect of omega-3 fatty acid supplementation during pregnancy alone on risk of autism spectrum disorder in the child (ages 36 months to 4 years), and neither study reported a statistically significant relationship (Table 7).

Assessment of the evidence:

Given the small number of studies in samples that may not reflect the diversity of the general U.S. population, as well as concerns regarding risk of bias due to confounding, classification of exposures, and the selection of reported results (Table 9), insufficient evidence existed to determine the relationship between omega-3 fatty acid supplementation during pregnancy alone and autism spectrum disorder in the child, and therefore a grade was not assignable.

\section{Supplementation during both pregnancy and lactation:}

\section{Summary:}

No studies examined the effect of omega-3 fatty acid supplementation during both pregnancy and lactation on risk of autism spectrum disorder in the child, and therefore a grade was not assignable.

\section{Supplementation during lactation alone:}

Summary:

No studies examined the effect of omega- 3 fatty acid supplementation during lactation alone on risk of autism spectrum disorder in the child, and therefore a grade was not assignable. 
Table 7. Description of evidence on relationship between omega-3 fatty acid supplementation and academic performance, risk of ADD/ADHD, or risk of Autism spectrum disorderxvi

\begin{tabular}{|c|c|c|c|c|}
\hline $\begin{array}{l}\text { Study and Participant } \\
\text { Characteristics }\end{array}$ & Intervention/Exposure & Outcome(s) & Results & Limitations \\
\hline \multicolumn{5}{|l|}{ Pregnancy Only } \\
\hline \multicolumn{5}{|l|}{ Academic Performance } \\
\hline $\begin{array}{l}\text { Gould, } 2017^{11} \mid \mathbf{R C T} \\
\text { Australia | DOMInO } \\
\mathbf{N}=543 \\
\text { Mothers were age } \sim 30 y \text { at } \\
\text { enrollment and } \sim 66 \% \text { completed } \\
\text { secondary education. } \\
\text { Race/ethnicity NR. }\end{array}$ & $\begin{array}{l}800 \mathrm{mg} / \mathrm{d} \text { DHA }+100 \mathrm{mg} / \mathrm{d} \text { EPA } \\
\text { vs Vegetable oil (rapeseed, } \\
\text { sunflower, and palm) placebo } \\
18-21 \text { wk through delivery }\end{array}$ & $\begin{array}{l}\text { WRAT-4 } \\
\text { at } 7 y\end{array}$ & $\begin{array}{l}\text { Non-significant: } \\
\text { All main effects } \\
\text { - Word reading } \\
\text { - Spelling } \\
\text { - Math computation }\end{array}$ & - No major limitations \\
\hline \multicolumn{5}{|l|}{ ADD/ADHD } \\
\hline $\begin{array}{l}\text { Gould, } 2017^{11} \mid \mathrm{RCT} \\
\text { Australia | DOMInO } \\
\mathrm{N}=543\end{array}$ & $\begin{array}{l}\text { Average supplemental Omega-3 } \\
(100 \mathrm{mg} / \mathrm{d}) \\
1 \mathrm{mo} \text { through delivery }\end{array}$ & $\begin{array}{l}\text { ADHD score } \\
\text { Conners } 3 \text { Al-parent } \\
\text { at } 7 y\end{array}$ & $\begin{array}{l}\text { Significant: } \\
\text { Favors control } \\
\text { ADHD score } \\
\text { Adj } P=0.02\end{array}$ & - No major limitations \\
\hline $\begin{array}{l}\text { Mothers were age } \sim 30 \text { y at } \\
\text { enrollment and } \sim 66 \% \text { completed } \\
\text { secondary education. } \\
\text { Race/ethnicity NR. }\end{array}$ & & & $\begin{array}{l}\text { Ref: Control } \\
\text { Adj Mean Difference: } \\
2.84,95 \% \mathrm{Cl}:(0.38 \text {, } \\
5.30)\end{array}$ & \\
\hline $\begin{array}{l}\text { Makrides, } 2014^{20} \mid \mathrm{RCT} \\
\text { Australia | DOMInO } \\
\mathrm{N}=646\end{array}$ & $\begin{array}{l}800 \mathrm{mg} / \mathrm{d} \text { DHA }+100 \mathrm{mg} / \mathrm{d} \text { EPA } \\
\text { vs Vegetable oil (rapeseed, } \\
\text { sunflower, and palm) placebo } \\
18-21 \text { wk through delivery }\end{array}$ & $\begin{array}{l}\text { Hyperactivity disorders: No } \\
\text { methodological details } \\
\text { at } 4 y\end{array}$ & $\begin{array}{l}\text { Non-significant: } \\
\text { - All main effects } \\
\text { Diagnosis }\end{array}$ & $\begin{array}{l}\text { - No methodological } \\
\text { details for hyperactivity } \\
\text { disorders } \\
\text { - Pre-registered analysis } \\
\text { plan NR }\end{array}$ \\
\hline
\end{tabular}

xvi ADD: attention deficit disorder; ADHD: attention-deficit/hyperactivity disorder; Adj: adjusted; ASD: autism spectrum disorder; Cl: confidence interval; DHA: docosahexaenoic acid; DOMInO: DHA to Optimize Mother Infant Outcome; EPA: eicosapentaenoic acid; MARBLES: Markers of Autism Risk in Babies-Learning Early Signs; NR: not reported; PCS: prospective cohort study; RCT: randomized controlled trial; WRAT-4: Wide Range Achievement Test Fourth Edition 


\begin{tabular}{|c|c|c|c|c|}
\hline $\begin{array}{l}\text { Study and Participant } \\
\text { Characteristics }\end{array}$ & Intervention/Exposure & Outcome(s) & Results & Limitations \\
\hline \multicolumn{5}{|l|}{$\begin{array}{l}\text { Mothers were age } \sim 29 \text { y at } \\
\text { enrollment and } \sim 68 \% \text { completed } \\
\text { more than secondary education. } \\
\text { Race/ethnicity NR. }\end{array}$} \\
\hline \multicolumn{5}{|l|}{ Autism Spectrum Disporder } \\
\hline $\begin{array}{l}\text { Makrides, } 2014^{20} \mid \mathrm{RCT} \\
\text { Australia | DOMInO } \\
\mathrm{N}=646\end{array}$ & $\begin{array}{l}800 \mathrm{mg} / \mathrm{d} \mathrm{DHA}+100 \mathrm{mg} / \mathrm{d} \text { EPA } \\
\text { vs Vegetable oil (rapeseed, } \\
\text { sunflower, and palm) placebo } \\
18-21 \mathrm{wk} \text { through delivery }\end{array}$ & $\begin{array}{l}\text { ASD diagnosis } \\
\text { at } 4 y\end{array}$ & $\begin{array}{l}\text { Non-significant: } \\
\text { All main effects } \\
\text { - Diagnosis }\end{array}$ & $\begin{array}{l}\text { - No methodological } \\
\text { details for ASD } \\
\text { diagnosis } \\
\text { - Pre-registered analysis } \\
\text { plan NR }\end{array}$ \\
\hline \multicolumn{5}{|l|}{$\begin{array}{l}\text { Mothers were age } \sim 29 y \text { at } \\
\text { enrollment and } \sim 68 \% \text { completed } \\
\text { more than secondary education. } \\
\text { Race/ethnicity NR. }\end{array}$} \\
\hline 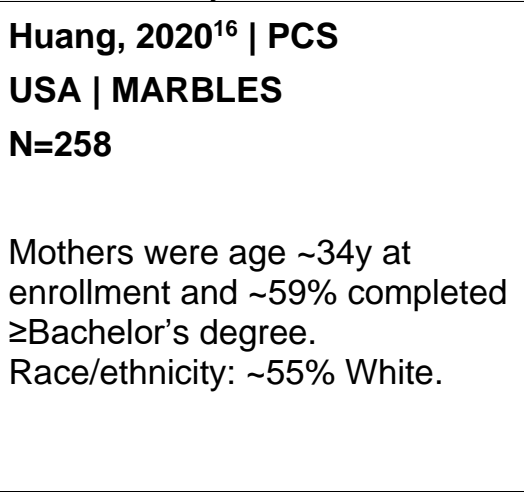 & $\begin{array}{l}\text { Omega-3 supplement intake } \\
(100 \mathrm{mg} / \mathrm{d} \text { increments }) \\
1 \mathrm{mo}-9 \mathrm{mo}\end{array}$ & $\begin{array}{l}\text { ASD diagnosis: Mullen Scales of } \\
\text { Early Learning, Autism Diagnostic } \\
\text { Observation Schedule } \\
\text { at } 36 \mathrm{mo}\end{array}$ & $\begin{array}{l}\text { Non-significant: } \\
\text { All main effects } \\
\text { - Diagnosis }\end{array}$ & $\begin{array}{l}\text { - Multiple key } \\
\text { confounders not } \\
\text { accounted for } \\
\text { - Critical co-exposures } \\
\text { NR } \\
\text { - No information on } \\
\text { missing outcome data, } \\
\text { but other missing data } \\
\text { appears to be balanced } \\
\text { across groups } \\
\text { - Pre-registered data } \\
\text { analysis plan NR }\end{array}$ \\
\hline
\end{tabular}


Table 8. Risk of bias for randomized controlled trials examining omega-3 fatty acid supplementation and developmental milestones, including neurocognitive development, in the childxvii xviii

\begin{tabular}{|c|c|c|c|c|c|}
\hline & Randomization & $\begin{array}{l}\text { Deviations } \\
\text { from intended } \\
\text { interventions }\end{array}$ & $\begin{array}{l}\text { Missing } \\
\text { outcome data }\end{array}$ & $\begin{array}{c}\text { Outcome } \\
\text { measurement }\end{array}$ & $\begin{array}{l}\text { Selection of the } \\
\text { reported result }\end{array}$ \\
\hline Brei, $2017^{1}$ & Low & Low & Some concerns & High & Some concerns \\
\hline Campoy, 2011² & Low & Low & Low & Low & Some concerns \\
\hline Catena, 2016 ${ }^{4}$ & Low & Low & Low & Low & High \\
\hline Catena, $2019^{3}$ & Low & Low & Low & Low & Some concerns \\
\hline Colombo, $2016^{5}$ & Low & Low & High & Low & Some concerns \\
\hline Colombo, $2019^{6}$ & Low & Low & Low & Low & Some concerns \\
\hline Dunstan, $2008^{7}$ & Low & Low & Some concerns & Low & Some concerns \\
\hline $\begin{array}{l}\text { Escolano-Margarit, } \\
2011^{8}\end{array}$ & Low & Low & Low & Some concerns & Some concerns \\
\hline Gould, 2014 ${ }^{10}$ & Low & Low & Low & Low & Some concerns \\
\hline Gould, 2016 ${ }^{9}$ & Low & Low & Some concerns & Low & Some concerns \\
\hline Gould, 2017'11 & Low & Low & Low & Low & Low \\
\hline Gustafson, $2013^{12}$ & Low & Low & Low & Low & Some concerns \\
\hline Helland, $2001^{13}$ & Some concerns & High & Some concerns & Low & Some concerns \\
\hline Helland, $2003^{15}$ & Some concerns & High & Some concerns & Low & Some concerns \\
\hline Helland, $2008^{14}$ & Some concerns & High & Some concerns & Low & Some concerns \\
\hline Innis, $2008^{17}$ & Low & Low & Some concerns & Low & Some concerns \\
\hline Jensen, $2005^{33}$ & Low & Low & Low & Low & Some concerns \\
\hline Jensen, $2010^{32}$ & Low & Low & Low & Low & Some concerns \\
\hline Keenan, 2016 ${ }^{18}$ & Low & Low & Some concerns & Low & Some concerns \\
\hline Makrides, $2010^{19}$ & Low & Low & Low & Low & Some concerns \\
\hline Makrides, $2014^{20}$ & Low & Low & Low & Low & Some concerns \\
\hline Malcolm, 2003 & Some concerns & High & Low & Low & Some concerns \\
\hline Meldrum, $2015^{22}$ & Low & Low & Some concerns & Low & Some concerns \\
\hline Mulder, 201324 & Low & Low & Low & Low & High \\
\hline Mulder, $2018^{23}$ & Low & Low & Low & Low & Some concerns \\
\hline Ostadrahimi, $2018^{25}$ & Low & Low & Low & Low & Some concerns \\
\hline Ramakrishnan, $2015^{27}$ & Low & Low & Low & Low & Some concerns \\
\hline Ramakrishnan, $2016^{26}$ & Low & Low & Low & Low/High & Some concerns \\
\hline
\end{tabular}

xvii A detailed description of the methodology used for assessing risk of bias is available on the NESR website: https://nesr.usda.gov/2020-dietary-guidelines-advisory-committee-systematic-reviews and in Part C of the following reference: Dietary Guidelines Advisory Committee. 2020. Scientific Report of the 2020 Dietary Guidelines Advisory Committee: Advisory Report to the Secretary of Agriculture and the Secretary of Health and Human Services. U.S. Department of Agriculture, Agricultural Research Service, Washington, DC.

xviii Possible ratings of low, some concerns, or high determined using the "Cochrane Risk-of-bias 2.0" (RoB 2.0) (August 2016 version)" (Higgins JPT, Sterne JAC, Savović J, Page MJ, Hróbjartsson A, Boutron I, Reeves B, Eldridge S. A revised tool for assessing risk of bias in randomized trials In: Chandler J, McKenzie J, Boutron I, Welch V (editors). Cochrane Methods. Cochrane Database of Systematic Reviews 2016, Issue 10 (Suppl 1). dx.doi.org/10.1002/14651858.CD201601.) 


\begin{tabular}{|c|c|c|c|c|c|}
\hline Smithers, $2011^{28}$ & Low & Low & Low & Low & Some concerns \\
\hline Stein, $2012^{29}$ & Low & Low & Low & Low & Some concerns \\
\hline van Goor, $2010^{30}$ & Some concerns & Low & Low & Low & Some concerns \\
\hline van Goor, $2011^{31}$ & Some concerns & Low & Low & Some concerns & Some concerns \\
\hline
\end{tabular}


Table 9. Risk of bias for observational studies examining omega-3 fatty acid supplementation and developmental milestones, including neurocognitive development, in the childxix

\begin{tabular}{|c|c|c|c|c|c|c|c|}
\hline & Confounding & $\begin{array}{l}\text { Selection of } \\
\text { participant }\end{array}$ & $\begin{array}{l}\text { Classification of } \\
\text { exposures }\end{array}$ & $\begin{array}{l}\text { Deviations from } \\
\text { intended } \\
\text { exposures }\end{array}$ & Missing data & $\begin{array}{c}\text { Outcome } \\
\text { measurement }\end{array}$ & $\begin{array}{l}\text { Selection of the } \\
\text { reported result }\end{array}$ \\
\hline Huang, $2020^{16}$ & Serious & Moderate & Serious & No Information & No Information & Moderate & Serious \\
\hline
\end{tabular}

xix Possible ratings of low, moderate, serious, critical, or no information determined using the "Risk of Bias for Nutrition Observational Studies" tool (RoB-NObs) (Dietary Guidelines Advisory Committee. 2020. Scientific Report of the 2020 Dietary Guidelines Advisory Committee: Advisory Report to the Secretary of Agriculture and the Secretary of Health and Human Services. U.S. Department of Agriculture, Agricultural Research Service, Washington, DC.) 


\section{Research recommendations}

- Strive to include participants who are reflective of the U.S. population on characteristics such as race/ethnicity, socioeconomic background, age, etc.

- Research is needed to determine whether the magnitude and/or direction of effects differ when omega-3 fatty acids are consumed as an individual nutrient supplement during pregnancy and/or lactation versus as in combination with a multivitamin/mineral supplement or in fortified foods, in relation to neurobehavioral development in the child.

- More research is needed to understand the relationship between omega-3 fatty acid supplementation during pregnancy and/or lactation and cognitive, language, motor, visual, and social-emotional development in the child. In particular, research should consider the baseline omega-3 fatty acid status of the mother and usual intakes in the U.S. population.

- More research is needed to understand the relationship between omega-3 fatty acid supplementation during pregnancy and/or lactation and academic performance in the child. In particular, research should consider the maternal baseline omega-3 fatty acid status and usual intakes in the U.S. population.

- More research is needed to understand the relationship between omega-3 fatty acid supplementation during pregnancy and/or lactation and risk of anxiety, depression, ADD/ADHD, and autism spectrum disorder in the child. In particular, research should consider the maternal baseline omega-3 fatty acid status and usual intakes in the U.S. population.

- Research is needed to understand the relationship between omega-3 fatty acid supplementation during pregnancy and/or lactation and risk of maternal anxiety and depression. In particular, research should consider the maternal baseline omega-3 fatty acid status and usual intakes in the U.S. population.

- Additional research is needed to better identify the time period(s) during pregnancy and/or lactation when an effect of omega-3 fatty acid supplementation on child development is more likely to be observed. Specifically, more studies are needed to investigate the effect of supplementation during both pregnancy and lactation, and during lactation alone on child development.

- Further research is needed to determine whether there are differential effects of the various forms of omega-3 fatty acid supplements during pregnancy and/or lactation on child development. 


\section{Included articles}

1. Brei C, Stecher L, Brunner S, et al. Impact of the n-6:n-3 long-chain PUFA ratio during pregnancy and lactation on offspring neurodevelopment: 5-year follow-up of a randomized controlled trial. Eur J Clin Nutr. 2017;71(9):1114-1120.doi: 10.1038/ejcn.2017.79.

2. Campoy C, Escolano-Margarit MV, Ramos R, et al. Effects of prenatal fish-oil and 5-methyltetrahydrofolate supplementation on cognitive development of children at 6.5 y of age. Am J Clin Nutr. 2011;94(6 Suppl):1880S-1888S.doi: 10.3945/ajcn.110.001107.

3. Catena A, Martinez-Zaldivar C, Diaz-Piedra C, et al. On the relationship between head circumference, brain size, prenatal long-chain PUFA/5methyltetrahydrofolate supplementation and cognitive abilities during childhood. Br J Nutr. 2019;122(s1):S40-S48.doi: 10.1017/S0007114516004281.

4. Catena A, Munoz-Machicao JA, Torres-Espinola FJ, et al. Folate and long-chain polyunsaturated fatty acid supplementation during pregnancy has long-term effects on the attention system of 8.5-y-old offspring: a randomized controlled trial. Am J Clin Nutr. 2016;103(1):115-127.doi: 10.3945/ajcn.115.109108.

5. Colombo J, Gustafson KM, Gajewski BJ, et al. Prenatal DHA supplementation and infant attention. Pediatr Res. 2016;80(5):656-662.doi: 10.1038/pr.2016.134.

6. Colombo J, Shaddy DJ, Gustafson K, et al. The Kansas University DHA Outcomes Study (KUDOS) clinical trial: long-term behavioral follow-up of the effects of prenatal DHA supplementation. Am J Clin Nutr. 2019;109(5):13801392.doi: $10.1093 /$ ajcn/nqz018.

7. Dunstan JA, Simmer K, Dixon G, Prescott SL. Cognitive assessment of children at age 2(1/2) years after maternal fish oil supplementation in pregnancy: a randomised controlled trial. Arch Dis Child Fetal Neonatal Ed. 2008;93(1):F4550.doi: 10.1136/adc.2006.099085.

8. Escolano-Margarit MV, Ramos R, Beyer J, et al. Prenatal DHA status and neurological outcome in children at age 5.5 years are positively associated. $J$ Nutr. 2011;141(6):1216-1223.doi: 10.3945/jn.110.129635.

9. Gould JF, Anderson AJ, Yelland LN, Gibson RA, Makrides M. Maternal characteristics influence response to DHA during pregnancy. Prostaglandins Leukot Essent Fatty Acids. 2016;108:5-12.doi: 10.1016/j.plefa.2016.03.011.

10. Gould JF, Makrides M, Colombo J, Smithers LG. Randomized controlled trial of maternal omega-3 long-chain PUFA supplementation during pregnancy and early childhood development of attention, working memory, and inhibitory control. Am J Clin Nutr. 2014;99(4):851-859.doi: 10.3945/ajcn.113.069203.

11. Gould JF, Treyvaud K, Yelland LN, et al. Seven-Year Follow-up of Children Born to Women in a Randomized Trial of Prenatal DHA Supplementation. JAMA. 2017;317(11):1173-1175.doi: 10.1001/jama.2016.21303.

12. Gustafson KM, Carlson SE, Colombo J, et al. Effects of docosahexaenoic acid supplementation during pregnancy on fetal heart rate and variability: a randomized clinical trial. Prostaglandins Leukot Essent Fatty Acids. 2013;88(5):331-338.doi: 10.1016/j.plefa.2013.01.009.

13. Helland IB, Saugstad OD, Smith L, et al. Similar effects on infants of $n-3$ and n6 fatty acids supplementation to pregnant and lactating women. Pediatrics. 2001;108(5):E82.doi: 10.1542/peds.108.5.e82. 
14. Helland IB, Smith L, Blomen B, Saarem K, Saugstad OD, Drevon CA. Effect of supplementing pregnant and lactating mothers with $n-3$ very-long-chain fatty acids on children's IQ and body mass index at 7 years of age. Pediatrics. 2008;122(2):e472-479.doi: 10.1542/peds.2007-2762.

15. Helland IB, Smith L, Saarem K, Saugstad OD, Drevon CA. Maternal supplementation with very-long-chain $\mathrm{n}-3$ fatty acids during pregnancy and lactation augments children's IQ at 4 years of age. Pediatrics. 2003;111(1):e3944.doi: 10.1542/peds.111.1.e39.

16. Huang $Y$, losif AM, Hansen RL, Schmidt RJ. Maternal polyunsaturated fatty acids and risk for autism spectrum disorder in the MARBLES high-risk study. Autism. 2020:1362361319877792.doi: 10.1177/1362361319877792.

17. Innis SM, Friesen RW. Essential n-3 fatty acids in pregnant women and early visual acuity maturation in term infants. Am J Clin Nutr. 2008;87(3):548-557.doi: 10.1093/ajcn/87.3.548.

18. Keenan K, Hipwell A, McAloon R, Hoffmann A, Mohanty A, Magee K. The effect of prenatal docosahexaenoic acid supplementation on infant outcomes in African American women living in low-income environments: A randomized, controlled trial. Psychoneuroendocrinology. 2016;71:170-175.doi: 10.1016/j.psyneuen.2016.05.023.

19. Makrides M, Gibson RA, McPhee AJ, et al. Effect of DHA supplementation during pregnancy on maternal depression and neurodevelopment of young children: a randomized controlled trial. JAMA. 2010;304(15):1675-1683.doi: 10.1001/jama.2010.1507.

20. Makrides M, Gould JF, Gawlik NR, et al. Four-year follow-up of children born to women in a randomized trial of prenatal DHA supplementation. JAMA. 2014;311(17):1802-1804.doi: 10.1001/jama.2014.2194.

21. Malcolm CA, McCulloch DL, Montgomery C, Shepherd A, Weaver LT. Maternal docosahexaenoic acid supplementation during pregnancy and visual evoked potential development in term infants: a double blind, prospective, randomised trial. Arch Dis Child Fetal Neonatal Ed. 2003;88(5):F383-390.doi:

10.1136/fn.88.5.f383.

22. Meldrum S, Dunstan JA, Foster JK, Simmer K, Prescott SL. Maternal fish oil supplementation in pregnancy: a 12 year follow-up of a randomised controlled trial. Nutrients. 2015;7(3):2061-2067.doi: 10.3390/nu7032061.

23. Mulder KA, Elango R, Innis SM. Fetal DHA inadequacy and the impact on child neurodevelopment: a follow-up of a randomised trial of maternal DHA supplementation in pregnancy. Br J Nutr. 2018;119(3):271-279.doi: 10.1017/S0007114517003531.

24. Mulder KA, King DJ, Innis SM. Omega-3 fatty acid deficiency in infants before birth identified using a randomized trial of maternal DHA supplementation in pregnancy. PLoS One. 2014;9(1):e83764.doi: 10.1371/journal.pone.0083764.

25. Ostadrahimi A, Salehi-Pourmehr H, Mohammad-Alizadeh-Charandabi S, Heidarabady S, Farshbaf-Khalili A. The effect of perinatal fish oil supplementation on neurodevelopment and growth of infants: a randomized controlled trial. Eur J Nutr. 2018;57(7):2387-2397.doi: 10.1007/s00394-0171512-1.

26. Ramakrishnan U, Gonzalez-Casanova I, Schnaas L, et al. Prenatal supplementation with DHA improves attention at $5 \mathrm{y}$ of age: a randomized 
controlled trial. Am J Clin Nutr. 2016;104(4):1075-1082.doi:

10.3945/ajcn.114.101071.

27. Ramakrishnan U, Stinger A, DiGirolamo AM, et al. Prenatal Docosahexaenoic Acid Supplementation and Offspring Development at 18 Months: Randomized Controlled Trial. PLoS One. 2015;10(8):e0120065.doi:

10.1371/journal.pone.0120065.

28. Smithers LG, Gibson RA, Makrides M. Maternal supplementation with docosahexaenoic acid during pregnancy does not affect early visual development in the infant: a randomized controlled trial. Am J Clin Nutr. 2011;93(6):1293-1299.doi: 10.3945/ajcn.110.009647.

29. Stein AD, Wang M, Rivera JA, Martorell R, Ramakrishnan U. Auditory- and visual-evoked potentials in Mexican infants are not affected by maternal supplementation with $400 \mathrm{mg} / \mathrm{d}$ docosahexaenoic acid in the second half of pregnancy. J Nutr. 2012;142(8):1577-1581.doi: 10.3945/jn.112.162461.

30. van Goor SA, Dijck-Brouwer DA, Doornbos B, et al. Supplementation of DHA but not DHA with arachidonic acid during pregnancy and lactation influences general movement quality in 12-week-old term infants. Br J Nutr. 2010;103(2):235-242.doi: 10.1017/S0007114509991528.

31. van Goor SA, Dijck-Brouwer DA, Erwich JJ, Schaafsma A, Hadders-Algra M. The influence of supplemental docosahexaenoic and arachidonic acids during pregnancy and lactation on neurodevelopment at eighteen months.

Prostaglandins Leukot Essent Fatty Acids. 2011;84(5-6):139-146.doi: 10.1016/j.plefa.2011.01.002.

32. Jensen CL, Voigt RG, Llorente AM, et al. Effects of early maternal docosahexaenoic acid intake on neuropsychological status and visual acuity at five years of age of breast-fed term infants. J Pediatr. 2010;157(6):900-905.doi: 10.1016/j.jpeds.2010.06.006.

33. Jensen CL, Voigt RG, Prager TC, et al. Effects of maternal docosahexaenoic acid intake on visual function and neurodevelopment in breastfed term infants. Am J Clin Nutr. 2005;82(1):125-132.doi: 10.1093/ajcn.82.1.125. 
The NESR team used its rigorous, protocol-driven methodology to support the 2020 Dietary Guidelines Advisory Committee in conducting this systematic review.

NESR's systematic review methodology involves:

- Developing a protocol,

- Searching for and selecting studies,

- Extracting data from and assessing the risk of bias of each included study,

- Synthesizing the evidence,

- Developing conclusion statements,

- Grading the evidence underlying the conclusion statements, and

- Recommending future research.

A detailed description of the methodology used in conducting this systematic review is available on the NESR website: https://nesr.usda.gov/2020-dietary-guidelines-advisory-committee-systematicreviews, and can be found in the 2020 Dietary Guidelines Advisory Committee Report, Part C: Methodology. ${ }^{x x}$ This systematic review was peer reviewed by Federal scientists, and information about the peer review process can also be found in the Committee's Report, Part C. Methodology. Additional information about this systematic review, including a description of and rationale for any modifications made to the protocol can be found in the 2020 Dietary Guidelines Advisory Committee Report, Chapter 2. Food, Beverage, and Nutrient Consumption During Pregnancy and Chapter 3. Food, Beverage, and Nutrient Consumption During Lactation.

Below are details of the final protocol for the systematic review described herein, including the:

- Analytic framework

- Literature search and screening plan

- Literature search and screening results

\section{ANALYTIC FRAMEWORK}

The analytic framework (Figure 1) illustrates the overall scope of the systematic review, including the population, the interventions and/or exposures, comparators, and outcomes of interest. It also includes definitions of key terms and identifies key confounders considered in the systematic review. The inclusion and exclusion criteria that follow provide additional information about how parts of the analytic framework were defined and operationalized for the review.

xx Dietary Guidelines Advisory Committee. 2020. Scientific Report of the 2020 Dietary Guidelines Advisory Committee: Advisory Report to the Secretary of Agriculture and the Secretary of Health and Human Services. U.S. Department of Agriculture, Agricultural Research Service, Washington, DC. 


\section{Figure 1: Analytic framework}

Systematic review question: What is the relationship between omega-3 fatty acids from supplements consumed before and during pregnancy and lactation and developmental milestones, including neurocognitive development, in the child?

\begin{tabular}{|c|c|c|}
\hline Intervention/exposure vs & Comparator & Outcomes \\
\hline $\begin{array}{l}\text { Exposure to, including } \\
\text { intake of, Omega-3 fatty } \\
\text { acids from: } \\
\text { - Dietary supplements } \\
\text { (including multiple- } \\
\text { nutrient supplements) } \\
\text { Population: Women before and } \\
\text { lactation; healthy and/or at risk for }\end{array}$ & $\begin{array}{l}\text { Different level of exposure } \\
\text { to, including intake of, } \\
\text { Omega-3 fatty acids } \\
\text { from: } \\
\text { - Dietary supplements } \\
\text { (including multiple- } \\
\text { nutrient supplements) } \\
\text { ring pregnancy and/or during } \\
\text { hronic disease }\end{array}$ & $\begin{array}{l}\text { - Developmental domains, examined via milestone } \\
\text { achievement and/or scales/indices, including: } \\
\text {. Cognitive, } \\
\text {. Language/communication, } \\
\text {. Sovement/physical, } \\
\text { - Academic performanal } \\
\text { - Attention deficit disorder (ADD) or attention- } \\
\text { deficit/hyperactivity disorder (ADHD) } \\
\text { - Anxiety } \\
\text { - Depression } \\
\text { - Autism spectrum disorder (ASD) } \\
\text { Population: Infants and toddlers (birth to } 24 \text { months), } \\
\text { children and adolescents (ages } 2-18 \text { years) }\end{array}$ \\
\hline
\end{tabular}

\section{Key definitions}

Dietary Supplement - a product (other than tobacco) that: is intended to supplement the diet; contains one or more dietary ingredients (including vitamins; minerals; herbs or other botanicals amino acids; and other substances) or their constituents; is intended to be taken by mouth as a pill, capsule, tablet, or liquid; and is labeled on the front panel as being a dietary supplement. (ODS; Dietary Supplement Health and Education Act, 1994)

"Before pregnancy"- includes up to 6 months before pregnancy.

\begin{tabular}{|c|c|}
\hline Legend & \\
\hline ….... & $\begin{array}{l}\text { The relationship of interest in the } \\
\text { systematic review } \\
\text { Factors that may impact the } \\
\text { relationship of interest in the } \\
\text { systematic review }\end{array}$ \\
\hline
\end{tabular}

\section{LITERATURE SEARCH AND SCREENING PLAN}

\section{Inclusion and exclusion criteria}

This table provides the inclusion and exclusion criteria for the systematic review. The inclusion and exclusion criteria are a set of characteristics used to determine which articles identified in the literature search were included in or excluded from the systematic review. 


\begin{tabular}{|c|c|c|}
\hline Category & Inclusion Criteria & Exclusion Criteria \\
\hline Study design & $\begin{array}{l}\text { - Randomized controlled trials } \\
\text { - Non-randomized controlled trials } \\
\text { including quasi-experimental and } \\
\text { controlled before-and-after studies } \\
\text { - Prospective cohort studies } \\
\text { - } \quad \text { Retrospective cohort studies } \\
\text { - Nested case-control studies }\end{array}$ & $\begin{array}{l}\text { - Uncontrolled trials } \\
\text { - } \text { Case-control studies } \\
\text { - Uncontrolled before-and-after } \\
\text { studies } \\
\text { - } \text { Cross-sectional studies } \\
\text { - } \quad \text { Narrative reviews } \\
\text { - Systematic reviews } \\
\text { - } \quad \text { Meta-analyses }\end{array}$ \\
\hline $\begin{array}{l}\text { Intervention/ } \\
\text { exposure }\end{array}$ & $\begin{array}{l}\text { Exposure to, including intake of, } \\
\text { Omega-3 fatty acids from: } \\
\text { Dietary supplements (including } \\
\text { multiple-nutrient supplements) }\end{array}$ & $\begin{array}{l}\text { Exposure to multiple-micronutrient } \\
\text { supplements in which nutrients } \\
\text { other than the nutrient of interest } \\
\text { vary }\end{array}$ \\
\hline Comparator & $\begin{array}{l}\text { Different levels of exposure to, } \\
\text { including intake of, Omega-3 fatty } \\
\text { acids from: } \\
\text { Dietary supplements (including } \\
\text { multiple-nutrient supplements) }\end{array}$ & $\begin{array}{l}\text { - } \\
\text { - Expo comparator } \\
\text { supplements in which nutrients } \\
\text { other than the nutrient of interest } \\
\text { vary }\end{array}$ \\
\hline $\begin{array}{l}\text { Outcome: } \\
\text { Developmental } \\
\text { milestones, } \\
\text { including } \\
\text { neurocognitive } \\
\text { health }\end{array}$ & $\begin{array}{l}\text { Developmental domains, } \\
\text { examined via milestone } \\
\text { achievement and/or scales/indices, } \\
\text { including: } \\
\text { ○ Cognitive, } \\
\text { ○ Language/communication, } \\
\text { ○ Movement/physical, } \\
\text { - Social-emotional } \\
\text { - Academic performance } \\
\text { - Attention deficit disorder (ADD) or } \\
\text { attention-deficit/hyperactivity } \\
\text { - } \text { disorder (ADHD) } \\
\text { - } \text { Anxiety } \\
\text { - Autism spectrum disorder (ASD) }\end{array}$ & - $N / A$ \\
\hline
\end{tabular}




Category Inclusion Criteria Exclusion Criteria

\begin{tabular}{lll}
\hline $\begin{array}{l}\text { Date of } \\
\text { publication }\end{array}$ & $\bullet$ January 1980 - February 2020 & Articles published prior to January \\
1980
\end{tabular}

\begin{tabular}{lll}
\hline $\begin{array}{l}\text { Publication } \\
\text { status }\end{array}$ & $\begin{array}{l}\text { Articles that have been peer- } \\
\text { reviewed }\end{array}$ & $\begin{array}{l}\text { Articles that have not been peer- } \\
\text { reviewed and are not published in } \\
\text { peer-reviewed journals, including }\end{array}$ \\
& $\begin{array}{l}\text { unpublished data, manuscripts, } \\
\text { reports, abstracts, and conference } \\
\text { proceedings }\end{array}$ \\
&
\end{tabular}

Language of
publication

\begin{tabular}{ll}
\hline Country $x \mathbf{x i}$ & $\begin{array}{l}\text { Studies conducted in countries } \\
\text { ranked as high or very high human } \\
\text { development }\end{array}$
\end{tabular}

- Articles published in languages other than English

- Studies conducted in countries ranked as medium or lower human development

$\begin{array}{lll}\text { Study } & \text { Human participants } \\ \text { participants }\end{array}$
- Non-human participants (e.g., animal or in-vitro models)
- Studies that exclusively enroll women who became pregnant using Assisted Reproductive Technologies
- Studies that exclusively enroll women with multiple gestation pregnancies
- Studies that enroll both singleton and multiple pregnancies and do not account for singleton and multiple gestation in the design or analyses and only present aggregate findings

\footnotetext{
xxiThe Human Development classification was based on the Human Development Index (HDI) ranking from the year the study intervention occurred or data were collected (UN Development Program. HDI 1990-2017 HDRO calculations based on data from UNDESA (2017a), UNESCO Institute for Statistics (2018), United Nations Statistics Division (2018b), World Bank (2018b), Barro and Lee (2016) and IMF (2018). Available from: http://hdr.undp.org/en/data). If the study did not report the year in which the intervention occurred or data were collected, the HDI classification for the year of publication was applied. HDI values are available from 1980, and then from 1990 to present. If a study was conducted prior to 1990, the HDI classification from 1990 was applied. If a study was conducted in 2018 or 2019, the most current HDI classification was applied. When a country was not included in the HDI ranking, the current country classification from the World Bank was used instead (The World Bank. World Bank country and lending groups. Available from: https://datahelpdesk.worldbank.org/knowledgebase/articles/906519-world-country-and-lending-groups).
} 


\begin{tabular}{|c|c|c|}
\hline Category & Inclusion Criteria & Exclusion Criteria \\
\hline $\begin{array}{l}\text { Life stage of } \\
\text { study } \\
\text { participants - } \\
\text { intervention or } \\
\text { exposure }\end{array}$ & $\begin{array}{l}\text { - Women up to } 6 \text { months before } \\
\text { pregnancy } \\
\text { - Women during pregnancy } \\
\text { - Women during lactation }\end{array}$ & - $\mathrm{N} / \mathrm{A}$ \\
\hline $\begin{array}{l}\text { Life stage of } \\
\text { study } \\
\text { participants - } \\
\text { outcomes }\end{array}$ & $\begin{array}{l}\text { Infants and toddlers (birth }-24 \\
\text { months) } \\
\text { Children and adolescents }(2-18 \\
\text { years) }\end{array}$ & $\begin{array}{l}\text { - Adults (19-64 years) } \\
\text { - Older adults (65 years and older) }\end{array}$ \\
\hline $\begin{array}{l}\text { Health status } \\
\text { of study } \\
\text { participants }\end{array}$ & $\begin{array}{l}\text { - Studies that enroll participants who } \\
\text { are healthy and/or at risk for chronic } \\
\text { disease, including those with obesity } \\
\text { - Studies that enroll some participants } \\
\text { diagnosed with a disease or with the } \\
\text { health outcome of interest: } \\
\text { O Neurocognitive disorders (ADD, } \\
\text { ADHD, anxiety, depression, or } \\
\text { ASD) } \\
\text { Studies that enroll some } \\
\text { participants who are deficient in } \\
\text { omega-3 fatty acids } \\
\text { - Studies that enroll some mothers } \\
\text { with infants who are born preterm } \\
\text { (<37 weeks and 0/7 days gestational } \\
\text { age) } \\
\text { - Studies that exclusively enroll or } \\
\text { enroll some mothers diagnosed with } \\
\text { the outcome of interest that is to be } \\
\text { examined in the infant/child } \\
\text { (developmental milestones, including } \\
\text { neurocognitive development) }\end{array}$ & $\begin{array}{l}\text { - Studies that exclusively enroll } \\
\text { participants diagnosed with a } \\
\text { disease, or hospitalized with an } \\
\text { illness or injury. (For this criterion, } \\
\text { studies that exclusively enroll } \\
\text { participants with obesity will not be } \\
\text { excluded.) } \\
\text { - Studies that exclusively enroll } \\
\text { participants with the outcome of } \\
\text { interest (i.e., studies that aim to treat } \\
\text { participants who have already been } \\
\text { diagnosed with the outcome of } \\
\text { interest) } \\
\text { - Studies that exclusively enroll } \\
\text { infants born preterm (gestational age } \\
<37 \text { weeks and } 0 / 7 \text { days), infants } \\
\text { with low birth weight (<2500g), } \\
\text { and/or infants born small for } \\
\text { gestational age }\end{array}$ \\
\hline
\end{tabular}




\section{Electronic databases and search terms}

\section{PubMed}

- Provider: U.S. National Library of Medicine

- Date(s) Searched: February 5, 2020

- Date range searched: January 1, 1980 - February 5, 2020

- Search Terms:

\#1 - "Fatty Acids, Omega-3"[Mesh] OR omega-3[tiab] OR N-3 fat*[tiab] OR N-3 polyunsat*[tiab] OR PUFA*[tiab] OR linolenic [tiab] OR eicosapentaenoic [tiab] OR EPA[tiab] OR docosahexaenoic acid*[tiab] OR DHA[tiab] OR ((fat [tiab] OR fats[tiab] OR fatty[tiab]) AND (unsatur* [tiab] OR monounsatur*[tiab] OR mono-unsatur*[tiab] OR polyunsatur*[tiab] OR polyunsatur ${ }^{*}\left[\right.$ tiab] )) OR fish oils[mh] OR fish oil* ${ }^{*}$ tiab] OR plant oils[mh] OR plant oil*[tiab] OR vegetable oil*[tiab] OR n-3 oil*[tiab] OR n3 oil*[tiab] OR n3 fat*[tiab]

\#2 - "Pregnancy"[Mesh] OR "Pregnancy Complications"[Mesh] OR "Maternal Exposure"[Mesh] OR "pregnant women"[Mesh] OR pregnan*[tiab] OR pre-pregnancy[tiab] OR prenatal[tiab] OR pre-natal[tiab] OR maternal[tiab] OR mother*[tiab] OR "Mothers"[Mesh] OR perinatal[tiab] OR peri-natal[tiab] OR pre-conception[tiab] OR preconception[tiab] OR peri-conception[tiab] OR periconception[tiab] OR "Peripartum Period"[Mesh] OR peripartum[tiab] OR peri-partum[tiab] OR gestat*[tiab] OR natal[tiab] OR antenatal[tiab] OR ante-natal[tiab] OR puerperium[tiab] OR "Maternal Nutritional Physiological Phenomena"[Mesh] OR "Postpartum Period"[Mesh] OR postpart*[tiab] OR post-part*[tiab] OR postnatal[tiab] OR post-natal[tiab] OR post-delivery[tiab] OR postdelivery[tiab] OR after birth[tiab] OR Lactation[Mesh] OR lactat*[tiab] OR breast feeding[Mesh] OR breastfe ${ }^{\star}[$ tiab] OR breast fe*[tiab] OR Milk, Human [Mesh] OR breastmilk[tiab] OR "breast milk"[tiab] OR "human milk"[tiab] OR "maternal milk"[tiab] OR "nursing women"[tiab]

\#3 - "Mental Disorders"[Mesh] OR mental disorder*[tiab] OR "Cognition"[Mesh] OR Neuropsychological Tests[MeSH] OR cogniti [tiab] OR metacogniti* [tiab] OR neurocogniti*[tiab] OR neurodevelop*[tiab] OR neurolog*[tiab] OR "Depression"[Mesh] OR depress*[tiab] OR anxi*[tiab] OR "Psychomotor Performance"[Mesh] OR psychomotor[tiab] OR motor skill*[tiab] OR "Executive Function"[Mesh] OR executive function*[tiab] OR attention deficit disorder*[tiab] OR attention deficit hyperactivity disorder*[tiab] OR ADHD[tiab] OR behavior disorder*[tiab] OR behaviour disorder*[tiab] OR behavioral disorder*[tiab] OR behavioural disorder ${ }^{*}[$ tiab] OR developmental disorder*[tiab] OR Autis ${ }^{\star}\left[\right.$ tiab] OR Asperger ${ }^{\star}[$ tiab] OR language processing[tiab] OR language delay*[tiab] OR "Child Development"[Mesh] OR child develop*[tiab] OR developmental delay[tiab] OR developmental disabilit*[tiab] OR "Problem Solving"[Mesh] OR problem solv*[tiab] OR developmental domain* OR academic[tiab] OR "Academic Performance"[Mesh]

\section{\#4 - \#1 AND \#2 AND \#3}

\#5 - \#4 NOT ("Animals"[Mesh] NOT ("Animals"[Mesh] AND "Humans"[Mesh])) NOT (editorial[ptyp] OR comment[ptyp] OR news[ptyp] OR letter[ptyp] OR review[ptyp] OR systematic review[ptyp] OR systematic review[ti] OR meta-analysis[ptyp] OR meta-analysis[ti] OR metaanalyses[ti] OR retracted publication[ptyp] OR retraction of publication[ptyp] OR retraction of publication[tiab] OR retraction notice[ti])

Filters: Publication date from 1980/01/01 to 2020/02/05; English 


\section{Cochrane Central Register of Controlled Trials (CENTRAL)}

- Provider: John Wiley \& Sons

- Date(s) Searched: February 5, 2020

- Date range searched: January 1, 1980 - February 5, 2020

- Search Terms:

\#1 - "linolenic acid" OR "omega 3" OR "omega-3" OR "N3 fatty acid*" OR "n-3 fat" OR pufa* OR "alpha-linolenic acid" OR "eicosapentaenoic acid*" OR "docosahexaenoic acid" OR [mh "Fatty Acids, Unsaturated"] OR ((fat OR fatty OR fats) NEAR/5 (unsatur* OR monounsatur* OR monounsatur" OR polyunsatur* OR poly-unsatur ${ }^{*}$ OR "linolenic acid")) OR [mh "fish oils"] OR fish oil ${ }^{\star}$ OR [mh "plant oils"] OR "plant oil" OR "vegetable oil*" OR "n-3 oil" OR "n3 oil" OR "n3 fat"

\#2 - [mh "Pregnancy"] OR [mh "Pregnancy Complications"] OR [mh "Prenatal Exposure Delayed Effects"] OR [mh "Maternal Exposure"] OR [mh "Pregnant Women"] OR [mh "Mothers"] OR [mh "Peripartum Period"] OR [mh "Maternal Nutritional Physiological Phenomena"] OR [mh "Postpartum Period"] OR pregnancy OR pre-pregnancy OR prenatal OR pre-natal OR maternal OR mother ${ }^{*}$ OR postpartum OR perinatal OR peri-natal OR pre-conception OR preconception OR peri-conception OR periconception OR peripartum OR peri-partum OR gestat* $O R$ natal OR antenatal OR ante-natal OR puerperium OR postpartum OR post-partum OR perinatal OR perinatal OR puerperium OR postpartal OR post-partal OR postnatal OR "post delivery" OR "after birth" OR [mh Lactation] OR [mh "Breast Feeding"] OR [mh "Milk, Human"] OR lact* OR breastfeeding OR breast-feeding OR breast feed* OR breast-feed* OR breastfed OR breast-fed OR breastfeed OR "human milk" OR "nursing women"

\#3 - [mh "Mental Disorders"] OR [mh "Cognition"] OR [mh "Cognitive Dysfunction"] OR [mh "Depressive Disorder"] OR [mh "Depression"] OR [mh "Psychomotor Performance"] OR [mh "Executive Function"] OR [mh "Attention Deficit and Disruptive Behavior Disorders"] OR [mh "Child Behavior Disorders"] OR "behavior disorder*" OR "behaviour disorder" OR "behavioral disorder" OR "behavioural disorder" OR "developmental disorder*" OR [mh "Child Development"] OR [mh "Autism Spectrum Disorder"] OR [mh "Developmental Disabilities"] OR [mh "Motor Skills Disorders"] OR [mh "Problem Solving"] OR "mental disorder" OR cognition OR cognitive OR metacognition OR neurocognitive OR neurodevelop* OR depression OR anxiety OR "motor skill*" OR "executive function*" OR "attention deficit disorder*" OR ADHD OR "developmental disorder*" OR autism OR autistic OR Asperger* OR "language processing" OR "language delay" OR "child develop*" OR "developmental delay" OR "developmental disabilit" OR "motor skill*" OR "developmental domain" OR "academic performance" OR [mh "academic performance"] OR "academic achievement" OR "academic failure" OR "academic success"

\#4 - \#1 AND \#2 AND \#3

Filters - Date limited from 1980 to 2020 , Trials

\section{Embase}

- Provider: Elsevier

- Date(s) Searched: February 5, 2020

- Date range searched: January 1, 1980 - February 5, 2020

- Search Terms:

\#1 - 'Omega 3 fatty acid'/exp OR 'linolenic acid"':ab,ti OR 'omega-3':ab,ti OR 'n-3 fatty acid':ab,ti 
OR pufa*:ab,ti OR 'alpha-linolenic acid*':ab,ti OR 'eicosapentaenoic acid':ab,ti OR 'docosahexaenoic acid"':ab,ti OR monounsatur":ti,ab OR mono-unsat*:ti,ab OR polyunsat*:ti,ab OR 'fish oils'/exp OR fish oil*:ti,ab OR 'plant oils'/exp OR 'plant oil':ti,ab OR 'vegetable oil ${ }^{\star *}:$ ti,ab OR 'n-3 oil':ti,ab OR 'n3 oil':ti,ab OR 'n3 fat':ti,ab

\#2 - pregnancy:ab,ti OR 'pre pregnancy':ab,ti OR prenatal:ab,ti OR 'pre natal':ab,ti OR maternal:ab,ti OR mother:ab,ti OR mothers:ab,ti OR 'pre conception':ab,ti OR preconception:ab,ti OR 'peri conception':ab,ti OR periconception:ab,ti OR peripartum:ab,ti OR 'peri partum':ab,ti OR gestation*:ab,ti OR natal:ab,ti OR antenatal:ab,ti OR 'ante natal':ab,ti OR postpartum:ab,ti OR post-partum:ab,ti OR perinatal:ab,ti OR 'peri natal':ab,ti OR puerperium:ab,ti OR postpartal:ab,ti OR post-partal:ab,ti OR postnatal:ab,ti OR 'post delivery':ab,ti OR 'after birth':ab,ti OR 'pregnancy'/exp OR 'pregnancy complication'/exp OR 'prenatal exposure'/exp OR 'maternal exposure'/exp OR 'pregnant woman'/exp OR 'mother'/mj OR 'puerperium'/exp OR 'maternal nutrition'/exp OR Lact*:ab,ti OR breastfeeding:ab,ti OR breast-feeding:ab,ti OR 'breast feed':ab,ti OR breastfed:ab,ti OR 'breast fed':ab,ti OR breastfeed:ab,ti OR 'human milk':ab,ti OR 'nursing women':ab,ti OR 'lactation'/exp OR 'breast feeding'/exp OR 'breast milk'/exp

\#3 - 'mental disease'/exp OR 'cognition'/exp OR 'cognitive defect'/exp OR 'depression'/exp OR 'psychomotor performance'/de OR 'executive function'/de OR 'attention deficit disorder'/de OR 'autism'/exp OR 'child development'/de OR 'developmental disorder'/exp OR 'psychomotor disorder'/de OR 'problem solving'/de OR 'academic performance'/exp OR 'mental disorder':ab,ti OR cognition:ab,ti OR cognitive:ab,ti OR metacognition:ab,ti OR neurocognitive:ab,ti OR neurodevelop*:ab,ti OR neurological:ab,ti OR depression:ab,ti OR anxiety:ab,ti OR 'executive function*':ab,ti OR 'attention deficit disorder':ab,ti OR adhd:ab,ti OR 'developmental disorder*':ab,ti OR autism:ab,ti OR asperger:ab,ti OR 'language processing':ab,ti OR 'language delay':ab,ti OR 'developmental delay':ab,ti OR 'developmental disabilit':ab,ti OR 'motor skill': ab,ti OR 'developmental domain*':ab,ti OR 'academic performance':ab,ti OR 'academic achievement':ab,ti OR 'academic failure':ab,ti OR 'academic success ${ }^{\star \prime}: a b, t i$

\#4 - \#1 AND \#2 AND \#3

\#5 - \#4 AND ([article]/lim OR [article in press]/lim) AND [humans]/lim AND [english]/lim AND [1980-2020]/py NOT ([conference abstract]/lim OR [conference paper]/lim OR [editorial]/lim OR [erratum]/lim OR [letter]/lim OR [note]/lim OR [review]/lim OR [systematic review]/lim OR [meta analysis]/lim)

\section{Cumulative Index of Nursing and Allied Health Literature (CINAHL Plus)}

- Provider: EBSCOhost

- Date(s) Searched: February 5, 2020

- Date range searched: January 1, 1980 - February 5, 2020

- Search Terms:

\#1 - "omega-3" OR "omega 3" OR "N-3 fat"" OR PUFA* OR "alpha-linolenic acid*" OR "eicosapentaenoic acid"” OR "docosahexaenoic acid" OR "linolenic acid"”R (MH "fish oils) OR fish oil* OR (MH "plant oils") OR "plant oil" OR "vegetable oil" OR "n-3 oil*" OR "n3 oil" OR "n3 fat*" OR (MH "Docosahexaenoic Acids") OR (MH "Eicosapentaenoic Acid")

\#2 - postpartum OR post-partum OR MH "Postpartum Period" OR postpartal OR post-partal OR postnatal OR post-natal OR "post deliver*" OR "after birth" OR MH "pregnancy" OR MH "pregnancy complications" OR MH "Prenatal Exposure Delayed Effects" OR MH "Maternal 
Exposure" OR MH "pregnant women" OR pregnan* OR pre-pregnancy OR prepregnancy OR prenatal OR antenatal OR maternal OR mother OR mothers OR perinatal OR peri-natal OR periconception OR periconception OR MH "Peripartum Period" OR peripartum OR peri-partum OR gestation* OR natal OR puerperium OR MH "Maternal Nutritional Physiological Phenomena" OR $\mathrm{MH}$ "Breast Feeding"OR breastfeeding OR breast-feeding OR MH "Milk, Human" OR "human milk" OR MH Lactation OR lactation OR lactating OR breastfeeding OR "breast feed" OR breast-feed" OR breastfed OR breast-fed OR breastfeed* OR "nursing women" OR "nursing mother"”

\#3 - (MH "Mental Disorders+") OR "mental disorder*" OR (MH "Cognition+") OR cognition OR cognitive OR metacognition OR neurocognitive OR neurodevelop* OR neurological OR "cognitive dysfunction" OR "depressive disorders OR (MH "Depression") OR depression OR (MH "Anxiety") OR anxiety OR (MH "Psychomotor Performance") OR motor skill* OR (MH "Executive Function") OR executive function* OR (MH "Attention Deficit Hyperactivity Disorder") OR attention deficit disorder* OR ADHD OR (MH "Child Behavior Disorders") OR (MH "Child Development") OR "child develop*" OR developmental disorder* OR (MH "Autistic Disorder") OR autism OR Asperger OR "language processing" OR language delay* OR (MH "Developmental Disabilities") OR developmental delay* OR developmental disabilit* OR (MH "Motor Skills Disorders") OR motor skill* OR (MH "Problem Solving") OR "problem solv*" OR developmental domain* OR (MH "academic performance") OR "academic performance" OR "academic achievement" OR "academic failure" OR academic success*

\#4 - \#1 AND \#2 AND \#3

\#5 - NOT (MH "Literature Review" OR MH "Meta-Analysis" OR MH "Systematic Review" OR MH "News" OR MH "Retracted Publication" OR MH "Retraction of Publication) Filters - Published Date: 1980-2020, English Language; Human

\section{LITERATURE SEARCH AND SCREENING RESULTS}

The flow chart (Figure 2) below illustrates the literature search and screening results for articles examining the systematic review question. The results of the electronic database searches, after removal of duplicates, were screened independently by two NESR analysts using a step-wise process by reviewing titles, abstracts, and full-texts to determine which articles met the inclusion criteria. Refer to Table $\mathbf{1 1}$ for the rationale for exclusion for each excluded full-text article. A manual search was done to find articles that were not identified when searching the electronic databases; all manually identified articles are also screened to determine whether they meet criteria for inclusion. 
Figure 2: Flow chart of literature search and screening results

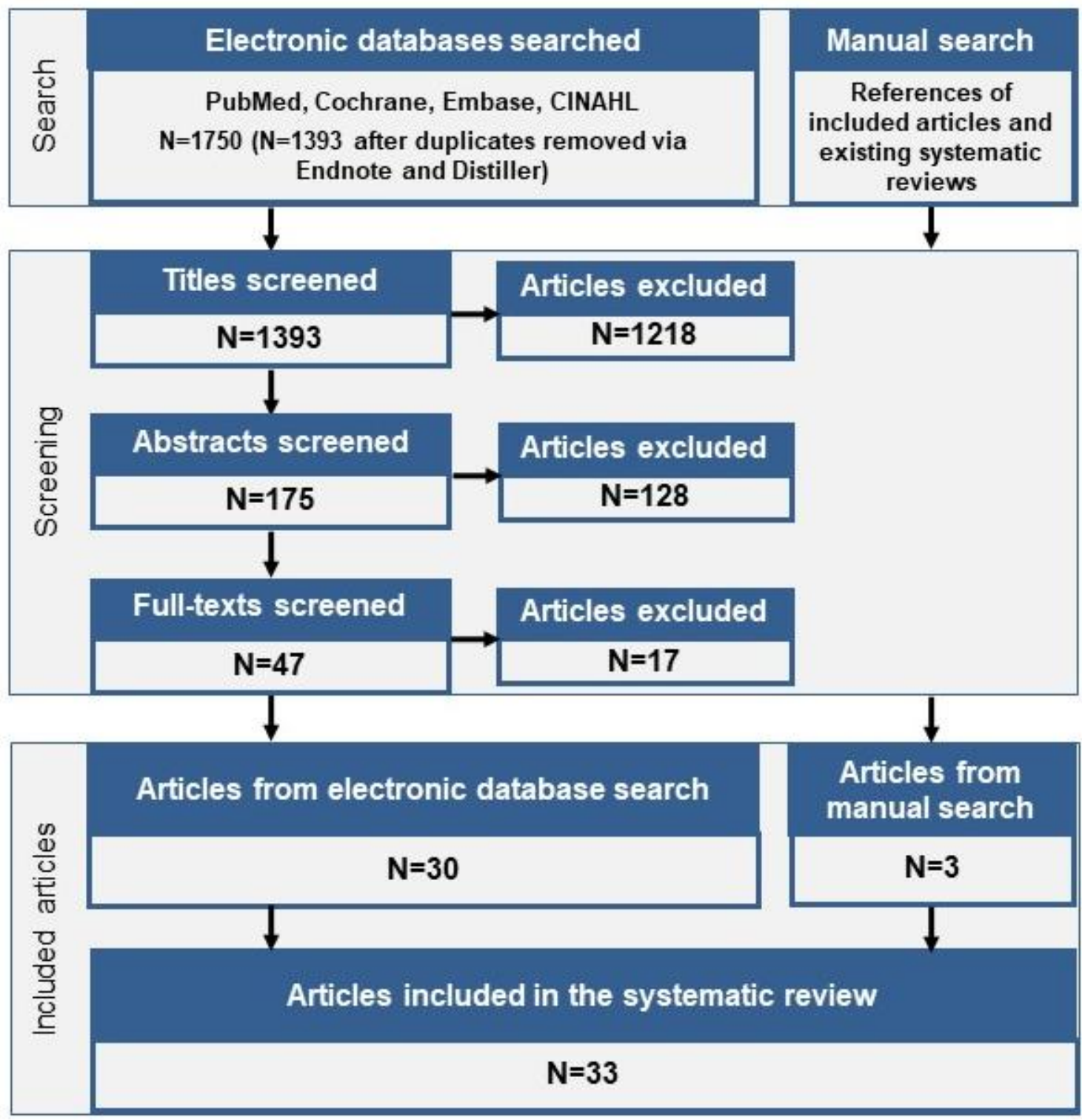




\section{Excluded articles}

The table below lists the articles excluded after full-text screening, and includes the categories of inclusion and exclusion criteria (see Table 10) that studies were excluded based on. At least one reason for exclusion is provided for each article, though this may not reflect all possible reasons for exclusion. Information about articles excluded after title and abstract screening is available upon request.

\section{Table 11. Articles excluded after full text screening with rationale for exclusion}

\begin{tabular}{|c|c|c|}
\hline & Citation & Rationale \\
\hline 1. & $\begin{array}{l}\text { Bernard, JY, De Agostini, M, Forhan, A, de Lauzon-Guillain, B, Charles, MA, Heude, B. The } \\
\text { dietary n6:n3 fatty acid ratio during pregnancy is inversely associated with child neurodevelopment } \\
\text { in the EDEN mother-child cohort. J Nutr. 2013. 143:1481-8. doi:10.3945/jn.113.178640 . }\end{array}$ & Intervention/Exposure \\
\hline 2. & $\begin{array}{l}\text { Campoy, C, Escolano-Margarit, MV, Ramos, R, Parrilla-Roure, M, Csábi, G, Beyer, J, Ramirez- } \\
\text { Tortosa, MC, Molloy, AM, Decsi, T, Koletzko, BV. Effects of prenatal fish-oil and 5- } \\
\text { methyltetrahydrofolate supplementation on cognitive development of children at } 6.5 \text { y of age1-5. } \\
\text { American Journal of Clinical Nutrition. 2011. 94:1880S-1888S. doi:10.3945/ajcn.110.001107. }\end{array}$ & Duplicate \\
\hline 3. & $\begin{array}{l}\text { Cheatham, CL, Nerhammer, AS, Asserhoj, M, Michaelsen, KF, Lauritzen, L. Fish oil } \\
\text { supplementation during lactation: effects on cognition and behavior at } 7 \text { years of age. Lipids. } \\
\text { 2011. 46:637-45. doi:10.1007/s11745-011-3557-x. }\end{array}$ & Intervention/Exposure \\
\hline 4. & $\begin{array}{l}\text { Gould, JF, Treyvaud, K, Yelland, LN, Anderson, PJ, Smithers, LG, Gibson, RA, McPhee, AJ, } \\
\text { Makrides, M. Does n-3 LCPUFA supplementation during pregnancy increase the IQ of children at } \\
\text { school age? Follow-up of a randomised controlled trial. BMJ Open. 2016. 6:e011465. } \\
\text { doi:10.1136/bmjopen-2016-011465. }\end{array}$ & Protocol \\
\hline 5. & $\begin{array}{l}\text { Hurtado, JA, Iznaola, C, Pena, M, Ruiz, J, Pena-Quintana, L, Kajarabille, N, Rodriguez-Santana, } \\
\text { Y, Sanjurjo, P, Aldamiz-Echevarria, L, Ochoa, J, Lara-Villoslada, F. Effects of Maternal Omega-3 } \\
\text { Supplementation on Fatty Acids and on Visual and Cognitive Development. J Pediatr } \\
\text { Gastroenterol Nutr. 2015. 61:472-80. doi:10.1097/mpg.0000000000000864 . }\end{array}$ & $\begin{array}{l}\text { Intervention/Exposure; } \\
\text { Fortified food }\end{array}$ \\
\hline 6. & $\begin{array}{l}\text { Jensen, CL, Voigt, RG, Prager, TC, Zou, YL, Fraley, JK, Rozelle, J, Turcich, M, Llorente, AM, } \\
\text { Heird, WC. Effects of maternal docosahexaenoic acid (DHA) supplementation on visual function } \\
\text { and neurodevelopment of breast-fed infants. Pediatric research. 2001. 49:448A. }\end{array}$ & Abstract \\
\hline 7. & $\begin{array}{l}\text { Kim, Y, Ha, EH, Park, H, Ha, M, Kim, Y, Hong, YC, Lee, EJ, Kim, H, Chang, N, Kim, BN. Prenatal } \\
\text { mercury exposure, fish intake and neurocognitive development during first three years of life: } \\
\text { Prospective cohort mothers and Children's environmental health (MOCEH) study. Sci Total } \\
\text { Environ. 2018. 615:1192-1198. doi:10.1016/j.scitotenv.2017.10.014. }\end{array}$ & Intervention/Exposure \\
\hline
\end{tabular}




\section{Citation}

\section{Rationale}

8. Lauritzen, L, Jørgensen, MH, Mikkelsen, TB, Skovgaard, IM, Straarup, EM, Olsen, SF, Høy, CE, Michaelsen, KF. Maternal fish oil supplementation in lactation: Effect on visual acuity and $n-3$ fatty acid content of infant erythrocytes. Lipids. 2004. 39:195-206. doi:10.1007/s11745-004-1220-8 .

9. Lauritzen, L, Jorgensen, MH, Olsen, SF, Straarup, EM, Michaelsen, KF. Maternal fish oil supplementation in lactation: effect on developmental outcome in breast-fed infants. Reprod Nutr Dev. 2005. 45:535-47. doi:10.1051/rnd:2005044 .

10. Malin, AJ, Busgang, SA, Cantoral, AJ, Svensson, K, Orjuela, MA, Pantic, I, Schnaas, L, Oken, E, Baccarelli, AA, Tellez-Rojo, MM, Wright, RO, Gennings, C. Quality of Prenatal and Childhood Diet Predicts Neurodevelopmental Outcomes among Children in Mexico City. Nutrients. 2018. 10. doi:10.3390/nu10081093 .

11. Miyake, Y, Tanaka, K, Okubo, H, Sasaki, S, Arakawa, M. Maternal fat intake during pregnancy Intervention/Exposure and behavioral problems in 5-y-old Japanese children. Nutrition. 2018. 50:91-96. doi:10.1016/j.nut.2017.12.001.

12. Ogaz-Gonzalez, R, Merida-Ortega, A, Torres-Sanchez, L, Schnaas, L, Hernandez-Alcaraz, C, Cebrian, ME, Rothenberg, SJ, Garcia-Hernandez, RM, Lopez-Carrillo, L. Maternal dietary intake of polyunsaturated fatty acids modifies association between prenatal DDT exposure and child neurodevelopment: A cohort study. Environ Pollut. 2018. 238:698-705. doi:10.1016/j.envpol.2018.03.100 .

13. Rees, A, Sirois, $S$, Wearden, $A$. Maternal docosahexaenoic acid intake levels during pregnancy and infant performance on a novel object search task at 22 months. Child Dev. 2014. 85:2131-9. doi:10.1111/cdev.12280.

14. Tofail, F, Kabir, I, Hamadani, JD, Chowdhury, F, Yesmin, S, Mehreen, F, Huda, SN. Supplementation of fish-oil and soy-oil during pregnancy and psychomotor development of infants. J Health Popul Nutr. 2006. 24:48-56.

15. Vollet, K, Ghassabian, A, Sundaram, R, Chahal, N, Yeung, EH. Prenatal fish oil supplementation and early childhood development in the Upstate KIDS Study. J Dev Orig Health Dis. 2017. 8:465473. doi:10.1017/s2040174417000253 .

16. Waylen, A, Ford, T, Goodman, R, Samara, M, Wolke, D. Can early intake of dietary omega-3 predict childhood externalizing behaviour?. Acta Paediatr. 2009. 98:1805-8. doi:10.1111/j.16512227.2009.01434.x

17. Zeng, J, Yu, W, Dong, X, Zhao, S, Wang, Z, Liu, Y, Wong, MS, Wang, Y. A nanoencapsulation suspension biomimetic of milk structure for enhanced maternal and fetal absorptions of DHA to improve early brain development. Nanomedicine. 2019. 15:119-128. doi:10.1016/j.nano.2018.09.006 .

Intervention/Exposure;

Fortified food

Intervention/Exposure;

Fortified food

Intervention/Exposure

Intervention/Exposure Intervention/Exposure

\section{Country}

Supplementation during pregnancy assessed postpartum Intervention/Exposure

\section{Human}

